Portland State University

PDXScholar

6-8-2018

\title{
Stakeholder Expectations of Islamic Education
}

Julia Marie Ahmed

Portland State University

Follow this and additional works at: https://pdxscholar.library.pdx.edu/open_access_etds

Part of the Educational Leadership Commons, and the Islamic Studies Commons Let us know how access to this document benefits you.

\section{Recommended Citation}

Ahmed, Julia Marie, "Stakeholder Expectations of Islamic Education" (2018). Dissertations and Theses. Paper 4395.

https://doi.org/10.15760/etd. 6279

This Dissertation is brought to you for free and open access. It has been accepted for inclusion in Dissertations and Theses by an authorized administrator of PDXScholar. Please contact us if we can make this document more accessible: pdxscholar@pdx.edu. 


\title{
Stakeholder Expectations of Islamic Education
}

\section{by}

\author{
Julia Marie Ahmed
}

A dissertation submitted in partial fulfillment of the requirements for the degree of

\author{
Doctor of Education \\ in \\ Educational Leadership: Curriculum and Instruction
}

\begin{abstract}
Dissertation Committee:
Susan Lenski, Chair

Swapna Mukhopadhyay

Dannelle Stevens

Sharon Carstens
\end{abstract}

Portland State University

2018 
(C) 2018 Julia Marie Ahmed 


\begin{abstract}
Teachers and parents make considerable sacrifices to affiliate themselves with Islamic schools. As they commit to Islamic education, they acquire certain expectations that they want their school to fulfill. The purpose of this study was to explore the academic, social, and cultural expectations of five teachers and five parents in an Islamic School on the West Coast in order understand how these expectations could be fulfilled in other Islamic schools across the United States. The main research questions of this study were: What are the academic, social, and cultural expectations that parents and teachers have of their Islamic schools? To what extent are Islamic schools meeting the expectations of parents and teachers? Qualitative, phenomenological research methods were used for the design of this study along with a purposeful sampling of teachers and parents, triangulation of data sources, and a thorough coding process.
\end{abstract}

Findings from the study supported that teachers and parents expected children to be knowledgeable about Islam in its broadest and deepest interpretations. Additionally, teachers and parents expected children to apply their knowledge of Islam in their everyday lives. Lastly, the degree that expectations were met depended on the support that teachers and parents received from their school community. When teachers and parents felt encouraged by school stakeholders, their expectations were generally fulfilled. Conversely, when teachers and parents felt that their needs were overlooked by school stakeholders, their expectations tended to remain unmet. Conclusions from the study explored ways to bridge the gap between met and unmet expectations of teachers 
and parents. Implications invited teachers and parents to move beyond expectations toward transformative educational experiences for children in Islamic schools. 
Dedicated to my children, Azrah, Abdul Rashid, and Khadijamy inspirations 


\section{Acknowledgements}

In the name of Allah, the most gracious, the most merciful. First, I thank Allah for making this dissertation possible. Next, I want to thank my adviser and committee chair, Susan Lenski, for your steadfast guidance throughout my dissertation journey. Thanks to Swapna Mukhopadhyaya and Dannelle Stevens, and Sharon Carstens for serving on my committee and providing the critical recommendations that strengthened my study. Thank you, Karen Noordhoff for mentoring me through the years. Thanks to my family for your patience and encouragement every step of the way. Thank you to my brother, Tony Browne, who kept me focused from start to finish. Thanks to the principal, teachers and parents who participated in my study. Without all of you, I could not have completed this dissertation. Thanks to my friends for believing that I could accomplish this project before I believed I could. Thanks to my classmate in the doctoral program, Diana Rodriguez (may your soul rest in peace) for your friendship and humor that helped ease the way. Thanks to my students, colleagues, parents and other community members at the Muslim Educational Trust who offered your support during my dissertation process. Finally, as a well-known Hadith states, first thank your mother, then your mother, then your mother, then your father. In that spirit, I thank my mother, Mary Ellen Browne and my father, David Edwin Browne (may your souls rest in peace), for being my first teachers. With your open minds and generous hearts, you exemplified the beauty and wonder of learning. May Allah bless you both and grant you Paradise. Ameen. 
Table of Contents

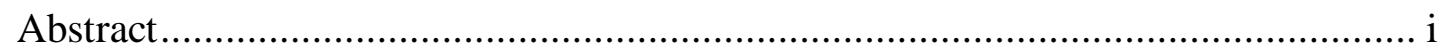

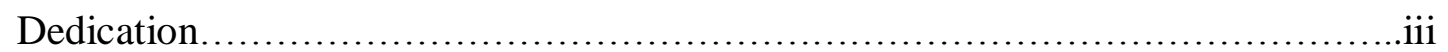

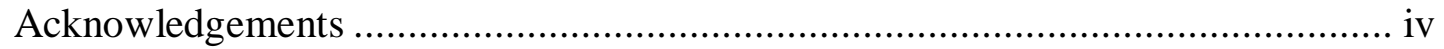

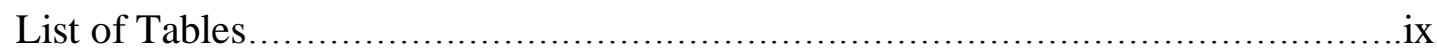

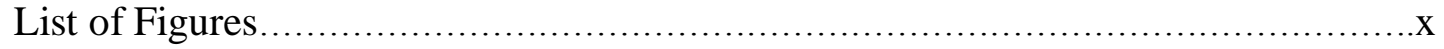

Chapter 1: Statement of the Research Problem...................................................... 1

Background of the Problem ..............................................................2

History of Islamic Education ............................................................. 3

Tarbiyah Project ............................................................................6

Islamic Schools and Madrasas .............................................................8

Statement of the Research Problem...................................... 9

Significance of the Research Problem...............................................11

Presentation of Methods and Research Questions ...............................12

Definition of Key Terms................................................................12

Chapter 2: Review of the Literature ........................................................... 14

Theoretical Framework............................................................... 14

Theory of Social Constructivism................................... 14

Differing Perspectives on Social Constructivism .................................16

Mediated Action Triangle ......................................................... 19

Cultural-Historical Activity Theory (CHAT) ...........................................20

Connection between Social Constructivism and Islamic Education ..........22

Perspective of Participants in Social Constructivism............................23

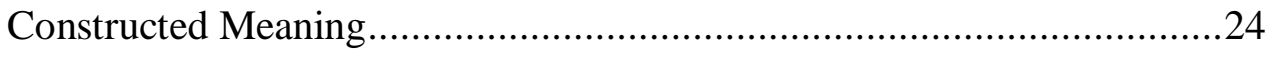

Different Interpretations of Expectations ..........................................24

Islamic Emphasis on Holistic Education .........................................25

Influence of Social Groups on Islamic Education................................26 
Limitations of Collaboration .............................................................28

Critique of Social Constructivism ...................................................29

Summary of the Theoretical Framework ............................................ 30

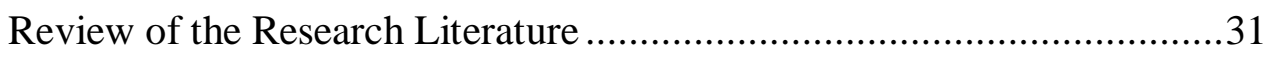

Background of Islamic Education ................................................ 31

Quran and Haddith as Origins of Islamic Knowledge ...........................32

To Grow, to Know, and to Discipline the Mind, Body and Soul...............34

The Spread of Islamic Educational Centers World-Wide .......................35

Expectations of Parents and Teachers ................................................38

Importance of Parents in Islam....................................... 38

Parents' Academic Expectations ........................................................40

Parents' Cultural Expectations ....................................................41

Importance of Teachers in Islam.................................... 43

Teachers' Expectations of Islamic Education...........................43

Teachers' Expectations to Make Pedagogical Distinctions................44

Teachers' Expectations to Teach from an Islamic Perspective ................45

Teachers' Expectations to Manage Classroom with Prophet as Example..45

Teachers' Expectations to Integrate Islamic Values into Classroom........46

Purpose of Learning from an Islamic Perspective ..............................4 47

Teachers' Expectations of Guidance in Navigating Diversity .................48

Teachers Expect Training on Integrating Islamic Curriculum ................49

Teachers' Expectations of Coaching on Students' Muslim Identity ..........50

Summary of Literature Review .....................................................51

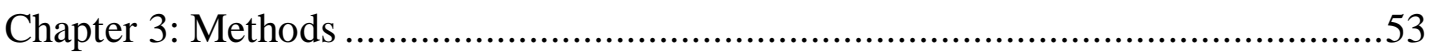

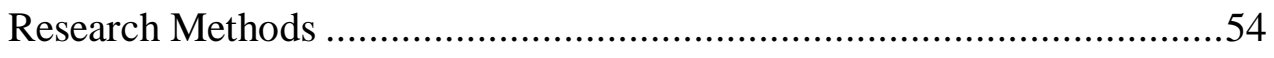

Participants.............................................................................59

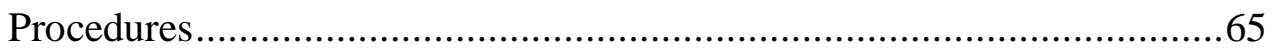

Instruments and Measures........................................66 
Role of Researcher.............................................71

Data Collection and Analysis................................................... 72

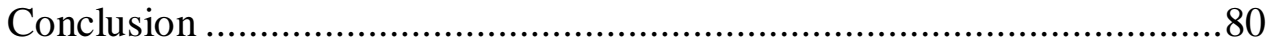

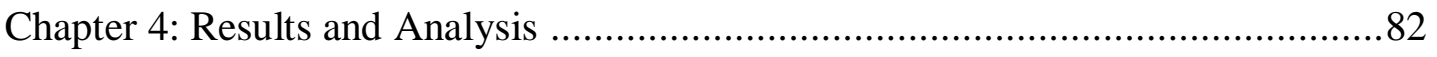

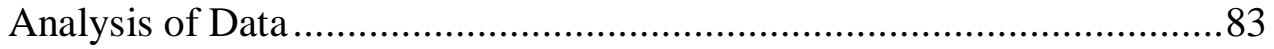

Preliminary Questionnaires..................................................... 83

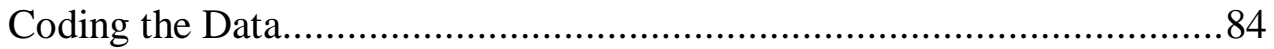

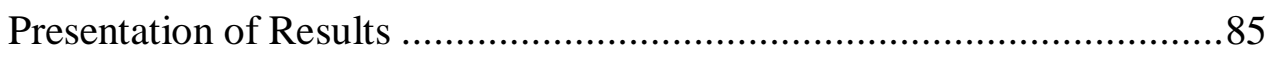

Preliminary Questionnaire-Teachers ...............................................8 85

Analysis of Preliminary Questionnaire-Teachers .................................86

Results of Preliminary Questionnaire-Parents .....................................87

Analysis of Preliminary Questionnaire-Parents ..................................8 88

Questionnaire Follow-up Themes-Teachers and Parents .......................89

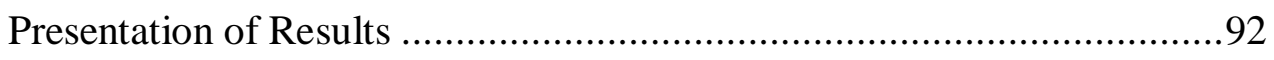

Teacher Interview Themes......................................92

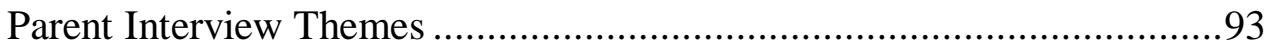

Organization and Presentation of Data and Analysis .............................94

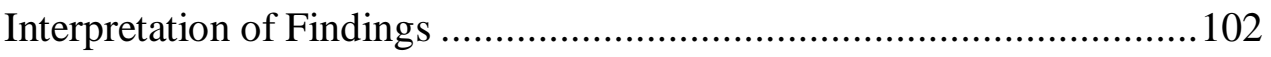

Expectation to be Knowledgeable about Islam.................................... 103

Summary of Expectation to be Knowledgeable about Islam..................114

Expectation to Apply Knowledge of Islam....................................... 114

Summary of Expectation to Apply Knowledge of Islam ...................... 122

Extent Islamic School Met Expectations ........................................ 123

Summary of Met Expectations .................................................... 133

How Islamic Schools are Falling Short of Expectations ....................... 134

Summary of Falling Short of Expectations............................ 144

Bracketing Out the Researcher's Experience ................................... 145

Experiences of the Participants .................................................. 148 


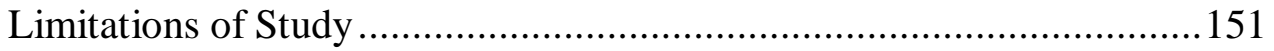

Limited Participants ............................................................ 151

Time Constraint ............................................................................ 151

Unfamiliarity of Participants................................................... 152

Diversity of Respondents...................................................... 154

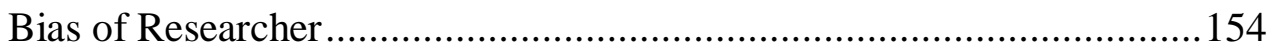

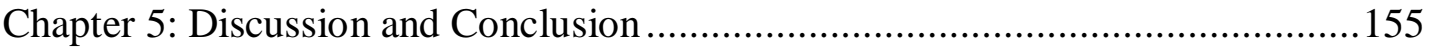

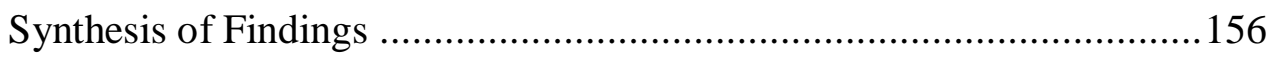

Social Constructivism Situated in Larger Context ...............................160

Expectations to be Knowledgeable ............................................. 163

Expectations to Apply Knowledge of Islam ...................................... 164

Met and Unmet Expectations ..................................................... 166

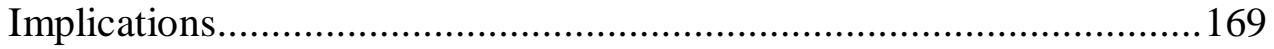

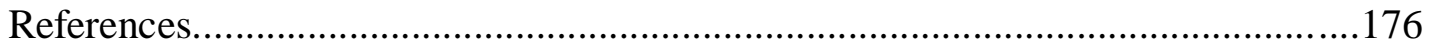

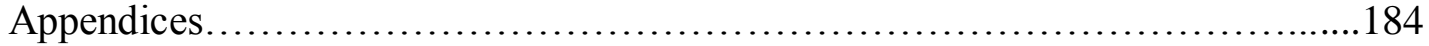

Appendix A Preliminary Questionnaire.............................184

Appendix B Questionnaire Follow-up..............................185

Appendix C Interview Questions.................................. 186 
List of Tables

Table 1. Purposeful Selection of Participants-Teachers 59

Table 2. Purposeful Selection of Participants-Parents $\quad 60$

$\begin{array}{lll}\text { Table 3. } & \text { Coding Columns } & 75\end{array}$

Table 4. Coding methods $\quad 83$

Table 5. Preliminary Questionnaire-Teachers $\quad 85$

Table 6. $\quad$ Preliminary Questionnaire-Parents 87

Table 7. Questionnaire Follow-Up-Teachers 90

Table 8. Questionnaire Follow-Up-Parents 91

Table 9. In-Depth Interview Themes-Teachers 94

Table 10. In-Depth Interview Themes-Parents $\quad 97$ 


\section{List of Figures}

Figure 1. Vygotsky's Basic Mediated Action Triangle

Figure 2. The Structure of a Human Activity System 


\section{Chapter 1: Statement of the Research Problem}

For the past fourteen years that I had been a parent and teacher at an Islamic school, I often asked myself what exactly I had expected from an Islamic education for my own three children. What did I want them to ultimately gain from their Islamic school experience? Furthermore, what had I expected from teaching at an Islamic school? I had also wondered what other parents and teachers expected from their Islamic school experience. I had seen many parents come and go through the years while others kept their children enrolled from pre- kindergarten through high school graduation. I was curious about the reasons why some parents decided to leave their Islamic school. Did they have expectations that were not being met? For the parents that remained at their Islamic school, I wondered what expectations they had that were being realized. Similarly, I had watched several teachers come one year and leave the next. On the other hand, several teachers had remained in their Islamic school classroom for many years. I was interested in the expectations of these teachers that were either being met or unmet.

Generally, the parents and teachers at my Islamic school are a culturally diverse group of individuals that is difficult to categorize. Their countries of origin include nearly every continent. Their native languages include Arabic, Somali, Urdu, Bangla, Bosnian, Turkish, Kurdish, Spanish, Kashmiri, Swahili, and others. Their levels of education range from emerging literacy to advanced degrees. Their religious practices span from conservative to liberal. Their adherence to traditional cultural practices, such as wearing hijab or eating halal meat, varies between strict compliance to casual observance. As I contemplated the educational expectations of the teachers and parents, three broad 
STAKEHOLDER EXPECATIONS OF ISLAMIC EDUCATION

categories of expectations emerged: social, cultural, and academic expectations.

Therefore, the purpose of this study was to explore the social, cultural, and academic expectations that parents and teachers have of Islamic schools. Furthermore, the goal for the study was to identify and eventually fill the gaps between the expectations and reality of Islamic schools.

\section{Background of the Problem}

To provide some context for this study, I introduce parents' and teachers' social, cultural, and academic expectations of Islamic schools. Then I discuss the history of Islamic education in its broadest context. Finally, I explain how the history of Islamic education relates to modern day Islamic schools in the United States. By examining these three concepts, I hope to position the problem through an analysis of its historical, social, and cultural contexts.

Parents and teachers in the study had a variety of expectations of Islamic schools due to their various roles, perspectives, and backgrounds. Muslim parents, for example, expected certain academic, social, and cultural outcomes as a result of committing their children to Islamic education. Renaerts (1999) stated, "They consider that the ideal

environment for reinforcing identity and formation of the social and religious character of children in Islamic spirit lies in a separate Islamic school system” (p. 290). Teachers, on the other hand, expected to be supported in their effort to integrate Islamic principles into the standard curriculum. Memon (2011) stated, "Islamic school teachers have emphasized the need to be trained in how to deliver topics from within an Islamic pedagogical framework" (p. 291). In this study, the range of parents' and teachers' expectations was 
examined, and a determination as to whether the various expectations are being met by Islamic schools was explored. I believe these three concepts - academic, social, and cultural - encompass the range of ideas needed to address my research questions.

\section{History of Islamic Education}

It was important to reflect on the origin of Islamic education for this study in order to understand the background and purpose of modern-day Islamic schools. The history of Islamic education could be traced to several Muslim scholars such as the thirteenth century philosophers Ibn Sina, Ghazsali, and Zarnuji whose works reflected the purposes of learning (Memon, 2011). Zarunji (2003), a thirteenth century Muslim scholar, described some of the qualities of Islamic pedagogy, including the "nobility of learning, the importance of intention when learning, the assiduity with which learning should be approached, and the purpose of learning being to put knowledge into action and control one's lower self through the very act of learning" (Memon, p. 288). While Zarunji (2003) venerated the act of learning, Ibn Sina (1984), the great tenth century Persian philosopher of the Islamic Golden Age, linked the acquisition of knowledge with gaining happiness: "Logic is the key to knowledge, and knowledge is the key to happiness, the highest human goal"' (p. 168). Al-Ghazsali (1962), the highly influential eleventh century Persian theologian echoed Ibn Sina's (1984) connection between knowledge and happiness: "The basis for happiness in this world and the next is knowledge" (p. 19). Furthermore, Ibn Rushd (1960), a well-known Andalusian Muslim philosopher and jurist of the twelfth century, as cited in Charafi (2003), wrote about the association between science, wisdom, and divine revelation: 
Our philosophy would serve for nothing if it were not able to link these three things which I have tried to join in my 'Harmony of Science and Religion': A Science, founded on experience and logic, to discover reasons. A Wisdom, which reflects on the purpose of every scientific research so that it serves to make our life more beautiful. A Revelation, that of our Qur'an as it is only through revelation that we know the final purposes of our life and our history. (p. 3-4) Lastly, Ibn Khaldun (1979), a North African Muslim historian from the fourteenth century who was considered one of the greatest Arab philosophers of The Middle Ages, explained three types of knowledge: "knowledge by inference, knowledge by perception and knowledge by personal experience" (Hussain and Ashraf, p. 95).

Shah (2016) expressed how Ibn Khadun (1979) described knowledge in the most comprehensive terms possible: "Its underlying principles of wholeness, unity and integration provide a wider base of knowledge that extends beyond dichotomies or limitations imposed by the senses to encompass the spiritual and divine" (Shah, 2016, pp. 20-21).

Where did philosophers such as Ibn Sina, Ghazsali, and Zarnuji, Ibn Rushd, Ibn Khaldun, and others acquire these enlightened ideas about learning and knowledge? The answer could be traced to the origins of Islam, specifically the Quran and Sunnah (sayings and teachings of the prophet Muhammad). Shah (2016) stated, "the Quran and Sunnah of the prophet Muhammad are the primary sources of knowledge and guidance for all Muslims, and also determine the Islamic worldview" (p. 14). Shah (2016) 
elaborated on the impact of the Quran and the Hadith (a collection of traditions containing sayings of the prophet Muhammad) on the expectations of Islamic education: The practices of Islamic education have been diverse, influenced by religious, social and political forces throughout Islamic history, but the principles of Islamic education have had a conceptual uniformity drawn from the Quran and the Hadith. Education takes place in a socio-political context; nevertheless, it is also informed by beliefs and ideologies. In the case of Islam, in spite of the socially embedded nature of education, the Islamic philosophy of knowledge has played a significant role in defining Islamic education and the expectations of education. (p. 36)

Shah's (2016) study explored the connection between the historical origins of Islamic education (the Quran and Sunnah) and modern day applications.

The scholarship of early Muslim educational philosophers guided modern Islamic educators toward establishing a pedagogy that provided direction, coherence, and identity for Islamic schools in the United States. Memon (2011) stated, "the recognition that a pedagogical tradition exists within Islamic scholarship can then be extended to question whether current Islamic school teachers are given the opportunity to consider the implementation of such a conceptual framework within contemporary Islamic schools" (p. 288). My study examined the pedagogical tradition within Islamic scholarship and how present-day Islamic schools followed a traditional conceptual framework. Moreover, my study explored whether the traditional conceptual framework met the expectations of Islamic school stakeholders. 
STAKEHOLDER EXPECATIONS OF ISLAMIC EDUCATION

Tarbiyah Project

An example of a traditional conceptual framework was the Tarbiyah Project, a character development program used in Islamic schools across the country, including the Islamic School of Kansas City, Kansas City, MO; Universal School, Bridgeview, IL; AlNoor School, Brooklyn, NY; and Crescent Academy International, Canton, MI, among others (Tauhidi, 2001, p. 16). Tarbiyah is an Arabic term meaning "to increase and grow" (Shah, 2016, p. 32). Tauhidi (2001) explained the vision of character growth for students attending Islamic schools that incorporated the Tarbiyah Project into the curriculum:

The Tarbiyah Project believes that the content of the Islamic Studies curriculum must be linked to the real needs and concerns of students and to the larger issues facing the world in which they live. The Tarbiyah Project curriculum is designed around nine specifically chosen content areas essential to character development. These include the areas of beliefs, rights, duties, values, manners, feelings, attitudes, and moral literacy skills. (Tauhidi, 2001, p. 10)

Students involved in the Tarbiyah Project were provided with opportunities to implement the nine content areas in real life applications:

Children become moral individuals through understanding, seeing and doing. By cultivating their minds and souls, and by giving them opportunities to see and practice values, students learn the importance of sound moral decisions and are more inclined to adopt them as their own. (Tauhidi, 2001, p. 12) 
STAKEHOLDER EXPECATIONS OF ISLAMIC EDUCATION

An example of a program within the Tarbiyah Project in which students put their faith into action is The Children for Charity program. Tauhidi, (2001) describes the program as

a service-learning program of systematic charity work and fund-raising by students. The purpose of this program is to get students to "think" about the needs of others and to "do something" to make their lives better. The focus of this program is not on collecting money, but rather on instilling in Muslim children a sense of social responsibility, a desire for helping others, and providing them with opportunities to develop the important values of giving and sharing, collective decision making (shurah), prioritizing, cooperation, and other core Islamic values. (pp. 14-15)

Other programs within the Tarbiyah Project that provided opportunities for students to act on their Islamic values included the Junior Leadership program in which students developed leadership skills by practicing public speaking, critical thinking, and problem-solving skills while working on class projects. In The Value of the Month program, students implemented a monthly core value into the general curriculum and found ways to activate those monthly values. Finally, in the Pillars of Power program, students developed their understanding of the five pillars of Islam (oneness of God, prayer, charity, fasting, and pilgrimage) by finding ways to apply the five pillars in the student's individual life as well as in the school and larger community.

The implementation of the Tarbiyah Project was an example of a traditional conceptual framework that Islamic schools in the United States used to provide direction, 
STAKEHOLDER EXPECATIONS OF ISLAMIC EDUCATION

coherence, and identity for Muslim students. Tauhidi, (2001) stated, "Islam is founded on the principles of belief and righteous conduct. This connection between values and practice lies at the very heart of the Islamic way of life" (p. 5). Whether Islamic schools incorporated the Tarbiyah Project or a different traditional conceptual framework, my study examined how an Islamic school's traditional conceptual framework met the expectations of teachers and parents.

\section{Islamic Schools and Madrasas}

For the purposes of this study, it was important to make the distinction between Islamic schools and madrasas. Islamic schools integrated the principles and practices of Islamic education into the general education curriculum. Haddad et al. (2009) explained, Most Islamic schools adopt the standards set by the state within which they are located and follow the basic curriculum that prepares students for standardized tests. Islamic parochial schools attempt to help students understand and preserve their Muslim identity by providing regular prayer, encouraging Islamic dress, providing halal meals, and integrating Islamic religious knowledge into the academic curriculum. (p. 12)

Madrasas, on the other hand, served a more specialized purpose than Islamic schools. Although the literal meaning of the Arabic word madrasa was "school," the secondary meaning pertained exclusively to religious instruction: "An educational institution offering instruction in Islamic subjects including, but not limited to, the Quran, the sayings (hadith) of the Prophet Muhammad, jurisprudence (fiqh), and law" 
STAKEHOLDER EXPECATIONS OF ISLAMIC EDUCATION

(Blanchard, 2007). This study examined full-time Islamic schools rather than madrasas, which would unnecessarily limit the research process.

\section{Statement of the Research Problem}

For a variety of academic, social, and cultural reasons, an increasing number of Muslim parents have recently decided to educate their children in Islamic schools rather than public schools. Haddad et al. (2009) estimated that 3.8 percent of Muslim children under the age of 18 attend full-time Islamic schools in the United States (p. 28). Muslim parents have contributed a considerable amount of time, money, and energy to provide their children with an Islamic education. Muslim parents are expected to volunteer in the classroom for a predetermined number of hours per year; pay a substantial monthly tuition fee ranging from approximately $\$ 4,000$ to 8,000 annually per child; contribute to fundraisers; and regularly participate in community events, such as workshops, interfaith gatherings, lectures, and other outreach efforts. Meanwhile, their children often attend Islamic schools that lack physical space, material resources such as science and computer labs, and opportunities for extracurricular activities. Muslim parents have the option of enrolling their children in local public schools that are publicly funded, offered a variety of extracurricular activities, and provided sufficient space for studying, playing, eating, and socializing. Muslim parents made considerable sacrifices to send their children to Islamic schools. What, then, were the academic, social, and cultural expectations that parents had for their children who attended Islamic schools? Furthermore, were Islamic schools meeting these parental expectations? 
Along with parents, teachers in Islamic schools made their own sacrifices in order to teach in an Islamic environment. Due to limited resources and lack of funding, Islamic school teachers received less pay, fewer benefits, and limited opportunities for training and advancement than public school teachers. However, Islamic school teachers had social, cultural, and spiritual expectations that may have transcended material aspirations. Many Islamic school teachers have moved from tight-knit communities in Muslim majority countries into loose-knit neighborhoods in the United States. Teaching in an Islamic school offers a sense of belonging in a familiar community. Although many Islamic school teachers originate from a variety of countries around the world, each with their own languages and traditions, they may expect to practice similar religious customs as in their home country when they teach in Islamic schools in the United States. Islamic customs, such as daily communal prayer and recitation of the Qur'an, regular acts of charity, annual fasting during the holy month of Ramadan, preparing for the pilgrimage (Hajj) to Mecca, sacrificing a lamb and distributing the meat to the needy during the Eid holiday, and the pervasive greeting of Salam (Peace), are important rituals for Muslims to observe; Islamic schools provide a favorable and communal environment for teachers to perform these practices.

Furthermore, many teachers expect to express their spiritual natures in Islamic schools. Since teachers are highly revered in Islam, teachers in Islamic schools expect students, colleagues, administration, and parents to support their efforts to uphold the noble qualities that are inherent in teaching. The question here is: How do Islamic schools live up to the expectations of their teachers? 
STAKEHOLDER EXPECATIONS OF ISLAMIC EDUCATION

\section{Significance of the Research Problem}

The purpose of this study was to gain a deeper understanding of what parents and teachers expected from Islamic schools in order to help these schools to better meet the expectations of these primary stakeholders. If the study revealed that there are disconnects in awareness of academic, social, and cultural expectations between parents and teachers, the aim of this study was to expose these disparities so that stakeholders' expectations were more likely to be realized in the future.

Issues of equity within the Islamic school environment were examined such as racial demographics of students and staff, teachers' salaries, parent involvement, and gender equity. The relationship between equity in Islam and educational expectations was explored in order to raise awareness of potential discrepancies between the Islamic ideal of social justice and the potential inequities in Islamic schools.

Since most Islamic schools are relatively new $-85 \%$ are ten years old or younger — little data were available about Islamic schools:

It is clear that there is a pressing need for further research. A comprehensive empirical study will strengthen the efforts of Muslim educators by providing the essential baseline data required to effectively analyze, plan, and develop policies that will significantly affect future generations of Muslims in America regarding issues of education and the pedagogy of Islamic schools. (Haddad et al., 2009, p. 264)

My hope was to contribute to the overall improvement of Islamic education in the United States through my research study. 
STAKEHOLDER EXPECATIONS OF ISLAMIC EDUCATION

Presentation of Methods and Research Questions

The purpose of my research was to understand what stakeholders expected from Islamic education. I used a qualitative approach as my method of research.

Phenomenology was the approach that I used to describe the shared experiences of teachers and parents of Islamic schools. To answer my research questions, I interviewed members of an Islamic school on the West Coast and analyzed current research studies on Islamic education in the United States.

The purpose of this study was to gain a deeper understanding of what parents and teachers expected from Islamic schools in order to help these schools to better meet the expectations of the primary stakeholders. The research problem was that Muslim parents and teachers may have certain educational expectations that were not being met by Islamic schools. The research questions were:

1. What were the academic, social, and cultural expectations that parents and teachers had of their Islamic schools?

2. To what extent were Islamic schools meeting the expectations of parents and teachers? How were Islamic schools meeting these expectations?

\section{Definition of Key Terms}

A Stakeholder is a person with a concern or interest in ensuring the success of an organization (Oxford English Dictionary, 2015). Stakeholders in Islamic schools include parents, teachers, students, administrators, and other community members who have a vested interest in the success of Islamic schools. 
An Expectation is a preconceived idea or opinion with regard to what will take place, forecasting something to happen, or anticipating something to be received (Oxford English Dictionary, 2015). Stakeholders have certain academic, social, and cultural expectations of Islamic education.

Islam is the Arabic word for "submission" to God, or "entering into the peace of God" (Ramadan, 2004). Islam is the faith that is practiced by the majority of the stakeholders in Islamic schools.

A Muslim is a person who practices the religion of Islam. Its origins are Arabic and its root is salam which has a dual meaning of peace and submission. A Muslim is one who finds peace through submitting to Allah, which means God in Arabic (Esposito, 1999). Islamic school stakeholders tend to be Muslims.

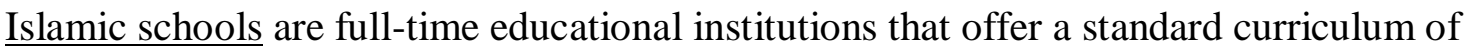
the arts and sciences, in addition to Islamic history, Quranic studies, and Arabic classes, in an elementary, middle, and high school setting. There are approximately 32,000 Muslim students who attend over 235 Islamic schools in the United States (Haddad, et al., 2009). 
STAKEHOLDER EXPECATIONS OF ISLAMIC EDUCATION

\section{Chapter 2: Review of the Literature}

In chapter one, I explained the need to examine the expectations of parents and teachers in Islamic schools. Parents and teachers have cultural, academic, and social expectations that their Islamic schools attempt to meet. The purpose of this study is to

gain a deeper understanding of what parents and teachers anticipate from Islamic schools in order to help these schools to better meet the expectations of the primary stakeholders. In chapter two, I review the literature about the academic, social, and cultural expectations of Islamic school stakeholders. After explaining my theoretical framework (social constructivism), I illustrate the connection between social constructivism and Islamic education. I conclude the chapter by describing the methods used to conduct the study.

\section{Theoretical Framework}

When parents send their children to Islamic school, they have certain cultural, academic, and social expectations for their children. Similarly, when teachers commit to teaching at an Islamic school, they too have certain cultural, academic, and social expectations in mind. To frame what these expectations are and how parents and teachers acquire these expectations, I used the theory of social constructivism which emphasizes that human beings co-create knowledge.

\section{Theory of Social Constructivism}

Social constructivism is a theory of knowledge that highlights the interdependent nature of human understanding whereby individuals collaborate to construct meaning. Prominent social constructivists, such as Vygotsky (1978), Bruner (1978), and Dewey 
(1938), argue that meaning is created collectively rather than individually. Other social constructivists make assumptions about the nature of reality, knowledge, and learning. For example, Kukla (2000) suggest that reality is created instead of discovered; Ernest (1999), Gredler (1997), and Prawat and Floden (1994) propose that knowledge is socially and culturally constructed; and McMahon (1997) argue that learning is active and social rather than passive and individualistic. Therefore, social constructivism embodies the collective nature of meaning, the creative nature of reality, the sociocultural nature of knowledge, and the socially active nature of learning.

Creswell (2013) explains this collaborative worldview that encompasses a creative, active, and sociocultural perspective on the meaning of life. Creswell (2013) describes social constructivism as a worldview in which people search for meaning in their lives, and they often find it by forging multifaceted interpretations of their experiences:

Individuals seek understanding of the world in which they live and work. They develop subjective meanings of their experiences. These meanings are varied and multiple, leading the researcher to look for the complexity of views rather than narrow the meanings into a few categories or ideas. (p. 24)

Here, Creswell (2013) emphasizes the need for researchers to reflect the intricacy of the human experience in order to accurately portray its depth and breadth.

This same desire to explore the consciousness of my subjects and to understand how their past experiences influences their future expectations is what led me to apply social constructivism as a theoretical framework for my research. Social constructivism 
allows me to delve into divergent points of view regarding stakeholder experiences within the Islamic school environment. For example, teachers and parents affiliated with Islamic schools originated from a multitude of countries around the world, including the United States. Whether they were from a rural village in Ethiopia, a bustling city in Bangladesh, or some point in between, these stakeholders brought elements of their diverse backgrounds with them into the Islamic school environment — teachers who grew up in conservative families during a civil war and fled to the United States as a refugees; fathers who grew up in secular, middle class families and moved to the United States on student visas; mothers who grew up in Christian families in the United States and converted to Islam as adults — there are as many scenarios of diverse stakeholder backgrounds as there are teachers and parents in Islamic schools. The school environment is where the divergent points of view of these stakeholders gets played out. What happens when these multifaceted teachers and parents converge in the Islamic school environment is a complex question that researchers using social constructivism as a theoretical framework attempt to answer due to its emphasis on finding meaning in various widespread ways.

\section{Differing Perspectives on Social Constructivism}

Bruner (1978) contributed to social constructivist theory by focusing on the social aspect of learning. Bruner (1996) suggested that education was most meaningful when accessed within a sociocultural context:

What we resolve to do in school only makes sense when considered in the broader context of what society intends to accomplish through its educational investment 
STAKEHOLDER EXPECATIONS OF ISLAMIC EDUCATION

in the young. How one conceives of education we have finally come to recognize, is a function of how one conceives of the culture and its aims, professed and otherwise. (p. ix-x)

Bruner's interest in the impact of poverty on education, resulting in the Head Start program, exemplified the application of the theoretical framework of social constructivism. This interconnection between education, culture, and its aims provided the structure to build upon a deeper understanding of the educational expectations of Islamic school stakeholders. What stakeholders expected of Islamic schools depended upon the cultural expectations within the larger Muslim community.

Dewey (1938), on the other hand, offered a time-based, progressive explanation of social constructivism, suggesting that individuals acquired an understanding of their world by building upon their previous experiences. In his description of the socially constructed connection between present reality and past activity, Dewey (1938) stated, "we live from birth to death in a world of persons and things which in large measure is what it is because of what has been done and transmitted from previous human activities" (p. 34). Dewey (1938) further elaborated on the obligation of teachers to create meaningful experiences for children from their physical and social environments that allow for their continuous development:

A primary responsibility of educators is that they not only be aware of the general principle of the shaping of the actual experience by environing conditions, but that they also recognize in the concrete what surroundings are conducive to having experiences that lead to growth. Above all, they should know how to utilize the 
surroundings, physical and social, that exist so as to extract from them all they have to contribute to building up experiences that are worthwhile. (p. 35)

Similarly, Islamic school stakeholders made use of their physical and social environments to create meaningful experiences in the classroom.

Just as Dewey emphasized building on previous experiences to create meaning, Vygotsky (1978) described how meaning is constructed through social interaction. Dewey (1978) illustrated social constructivism in his portrayal of a child who was pointing at an object, and the subsequent meaning of the gesture that developed between the child and mother. Only when the child understood that pointing at an object resulted in a reaction by the mother did the pointing become meaningful for the child. Vygotsky (1978) explained,

It becomes a true gesture only after it objectively manifests all the functions of pointing for others and is understood by others as such a gesture. Its meaning and function are created at first by an objective situation and then by people who surround the child. (p. 56)

Social constructivism depended upon the interaction of people in order to create meaning. Vygotsky (1978) explained, “all the higher functions (voluntary attention, logical memory, and formation of concepts) originate as actual relations between human individuals" (p. 57). Likewise, parents and teachers formed their expectations of Islamic schools through their interaction with others in the community. Shah (2016) stated, The role of Islamic education is perceived to give meaning to life and enrich it, instilling discipline and preserving human values, strengthening and advancing 
STAKEHOLDER EXPECATIONS OF ISLAMIC EDUCATION

human societies. The argument is explicit that education in Islam should aim to prepare human beings for leading a life of 'righteousness' in a social context. These perceptions contribute to enhanced expectations of Muslim learners and communities of education in diverse contexts. (p. 24)

This meaningful interaction between members of the larger community and Islamic school stakeholders allowed for the emergence of educational expectations.

\section{Mediated Action Triangle}

Engeström (2001) illustrated how people co-create meaning in the world using Vygotsky's mediated action triangle as a model (see Fig.1): "Vygotsky’s idea of cultural mediation of actions was commonly expressed as the triad of subject, object, and mediating artifact" (p. 134). The subject represented the person who participated in the activity; the tools included artifacts, social others, and prior knowledge of the activity; the object corresponded to the purpose of the activity. Engeström (2001) described the interdependent components of the mediated action triangle: "The individual could no longer be understood without his or her cultural means; and the society could no longer be understood without the agency of individuals who use and produce artifacts" (p. 134). Similarly, in an Islamic school environment, the interdependent components included stakeholders who could be understood within their culture framework, and the Islamic community that could be understood with the support of stakeholders who use and produce artifacts, such as knowledge. 


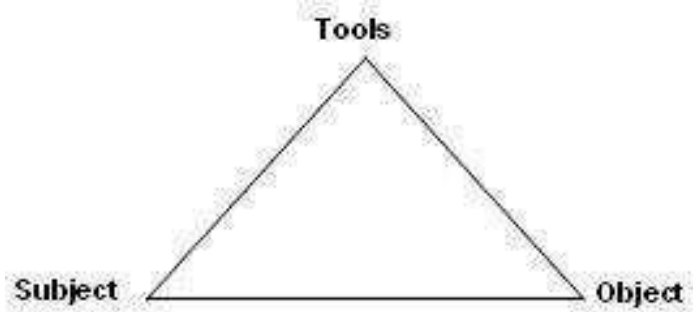

Fig. 1 Vygotsky’s basic mediated action triangle adapted from Engeström (2001).

The interaction between the subject, tools, and object was a dynamic process in which individuals simultaneously made meaning of the world while co- constructing and reconstructing ideas and their purpose. In an Islamic school context, the subject represented the stakeholders (parents and teachers); the tools included students, administration, community members with an invested interest in Islamic education, the Quran, and Hadith; the object was the goal, (expectations) of Islamic education, as defined by the stakeholders.

\section{Cultural-Historical Activity Theory (CHAT)}

Engeström (1987) added another layer of complexity to Vygotsky’s mediated action triangle in his explanation of the structure of a human activity system (see Fig. 2). Using cultural-historical activity theory (CHAT), Engeström (1993) explained that an activity system was comprised of "a multitude of often disparate elements, voices, and viewpoints. This multiplicity can be understood in terms of historical layers. An activity system always contains sediments of earlier historical modes, as well as buds or shoots of its possible future" (p. 68). Similarly, it is useful to understand parents, teachers, and their 
expectations through the lens of an activity system that accounts for the multiple

perspectives within a historically rich Islamic community which is forging its future collaboratively.

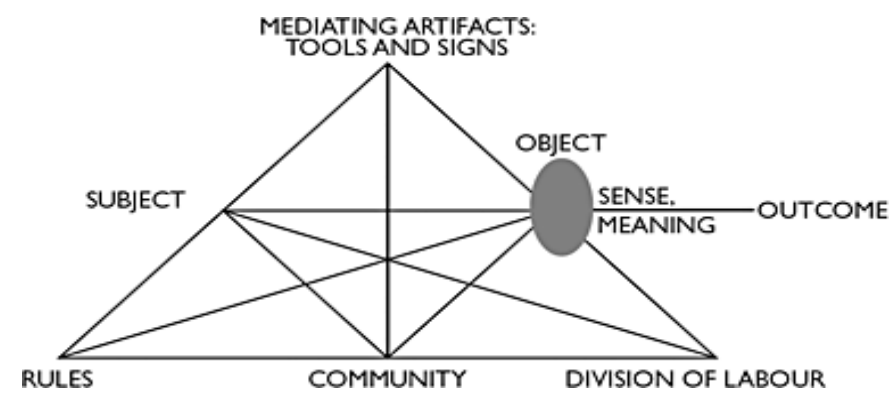

Fig. 2 The structure of a human activity system (Engeström, 1987, p. 78)

Using CHAT to describe the components of the uppermost triangle of the human activity system (mediating artifacts, subject, and object), Engeström (1987) explained, Cultural-historical activity theory looks at artifacts and people as embedded in dynamic activity systems. If we think of a designer as the subject of her design work, the initial object would be an idea, order or assignment that triggers the design process. The initial object is necessarily ambiguous, requiring interpretation and conceptualization. Thus, the object is step-by- step invested with personal sense and cultural meaning. The object goes through multiple transformations until it stabilizes as a finished outcome. (p. 1)

CHAT allowed for conceptualizing parents and teachers as designers of personally and culturally meaningful ideas they formulated about their Islamic school expectations. 
STAKEHOLDER EXPECATIONS OF ISLAMIC EDUCATION

In his description of the bottom part of the human activity system triangle (rules, community, and division of labor), Engeström (1987) stated,

The figure calls attention to the work community in which the designer is a member." He goes on to say, "Within the community, the members continuously negotiate their division of labor, including the distribution of rewards. The temporal rhythms of work, the uses of resources, and the codes of conduct are also continuously constructed and contested in the form of explicit and implicit rules. (p. 2)

CHAT allowed for situating parents and teachers working within complex, rule- bound education communities, creating ideas together while navigating shared resources.

Furthermore, CHAT fit into the study by illustrating social constructivism in the form of a diagram that explained the dynamic, interdependent components of the study, namely stakeholders (parents and teachers), artifacts (students, culture, knowledge, history, Qur'an, Hadith), and goals (expectations) of Islamic education.

\section{Connection between Social Constructivism and Islamic Education}

The rationale for selecting social constructivism as a theoretical framework to inform the study directly related to Islamic school stakeholders and their expectations of Islamic education. Parents and teachers acquired certain expectations of Islamic education through their tightly woven interaction with one another. These closely integrated Islamic school communities included individuals from a variety of ethnic, socioeconomic, cultural, and linguistic backgrounds.Furthermore, Islamic school communities contained classrooms with parents who were teachers, school offices with 
STAKEHOLDER EXPECATIONS OF ISLAMIC EDUCATION

parents who were administrators, and classrooms led by teachers who were Islamic school alumnus. Each of these venues created a rich environment for stakeholders to create a shared sense of community, as well as a set of academic, social, and cultural expectations for their community to meet.

\section{Perspective of Participants in Social Constructivism}

Examining Islamic school expectations through the lens of social constructivism allowed for maximum input from key stakeholders. The aim of the study was to understand the nature of the expectations that stakeholders acquired regarding Islamic schools: What were their expectations? How did stakeholders form these expectations? What and who were the influences that impacted stakeholders as they established expectations? One way to understand the meaning of these subjective expectations was to fully depend on participants to trace back the historical and social origins of their expectations. Creswell (2013) stated,

The goal of research is to rely as much as possible on the participants' view of the situation. Often, these subjective meanings are negotiated socially and historically. In other words, they are not simply imprinted on individuals but are formed through interaction with others [hence social construction] and through historical and social norms that operate in individuals' lives. (pp. 24-25) Social constructivism as a theoretical framework recognized the historical and cultural norms that influenced stakeholder expectations of Islamic schools.

While Creswell (2013) emphasized the historical and cultural aspects of social 
constructivism, Crotty (2013) made the distinction between social constructivism and social constructionism. Crotty (1998) defined constructionism as "the view that all knowledge, and therefore all meaningful reality as such, is contingent upon human practices, being constructed in and out of interaction between human beings and their world, and developed and transmitted within an essentially social context" (p. 42). That is, the academic, social, and cultural expectations of Islamic education were socially constructed by Islamic school stakeholders.

\section{Constructed Meaning}

Crotty (1998) further explained that meaning was constructed rather than discovered: "Meanings are constructed by human beings as they engage with the world they are interpreting. Before there were consciousnesses on earth capable of interpreting the world, the world held no meaning at all" (p. 43). Put into an Islamic context, Islamic school stakeholder expectations were meaningful due to the historical and cultural norms that were socially constructed by the Muslim community.

\section{Different Interpretations of Expectations}

However, the meaning that stakeholders construct regarding their expectations of Islamic schools varies due to contextual differences. Crotty (1998) stated, "historical and cross-cultural comparisons should make us very aware that, at different times and in different places, there have been and are very divergent interpretations of the same phenomena" (p. 64). For example, stakeholders constructed different expectations of Islamic education after $9 / 11$; stakeholders who maintain a religiously conservative perspective constructed different expectations of Islamic education than their more liberal 
counterparts; stakeholders who attended Islamic schools in their home country constructed different educational expectations than those who attended secular schools.

In his summary of social constructivism, Crotty (1998) stated, "we need to recognize that different people may well inhabit quite different worlds. Their different worlds constitute for them diverse ways of knowing, distinguishable sets of meaning, separate realities" (p. 64). Social constructivism has allowed stakeholders to express different ways of understanding Islamic education, to interpret what Islamic education meant to them, and to understand the reality of Islamic education in their own way. Crotty (1998) explained,

This means that description and narration can no longer be seen as straightforward representational of reality. It is not a case of merely mirroring 'what is there'. When we describe something, we are, in the normal course of events, reporting how something is seen and reacted to, and thereby meaningfully constructed, within a given community or set of communities. When we narrate something, even in telling our very own story, it is [again in the normal course of events] the voice of our culture [its many voices, in fact] that is heard in what we say. (p. 64) Social constructivism has allowed for the variety of voices within the Islamic school culture to be expressed.

\section{Islamic Emphasis on Holistic Education}

Islamic school stakeholders have turned to the Qur'an, which “emphasizes education for the holistic development of the self and society" to help construct beliefs about education (Shah, 2016, p. 3). Shah (2016) explained that "the Quran stresses 
inquiry and reflection while emphasizing shura (consultation) and ijtihad (rational consensus), and creates space for ikhtilaf (disagreement) with regard to all debates and reflections" (p. 2). Shah (2016) argued, "an education that does not align with these principles cannot claim to be Islamic. Shura (consultation), ijtihad (rational consensus) and ikhtilaf (disagreement, diversity, pluralism) are ideologically the essential principles of an Islamic education" (p. 3).

Shah (2016) stated that a holistic education includes "moral, intellectual, spiritual, material, and social" development (p. 3). Furthermore, Shah (2016)highlighted the responsibility that Islamic schools undertook for other social groups: "The social dimension of education underlining individuals' responsibility toward others is reflected in an emphasis on obligations to other human beings, which is aimed at collective good" (p. 3), including Muslims and non-Muslims alike. Fundamental for Islamic school stakeholders was education that transcended earthly knowledge that centered on the individual, toward a spiritual understanding that included and benefited the whole of humanity.

\section{Influence of Social Groups on Islamic Education}

Other social groups, in turn, have influenced Islamic school stakeholders. Haddad et al. (2009) described a study in which annual school visits to an Islamic school by nonMuslim students had a transformative effect on both groups. Such authentic school visits served to validate the religious identity of Muslim students. One student reflected, "I was sort of nervous since I was a Muslim myself and worried that people might say something." After witnessing her classmates' positive reaction to the visit, however, she 
felt "happy and relieved" (Haddad et al., 2009, p. 239). School visits were a way of fulfilling religious obligations for both parties.Another student observed, "Many nonMuslims have the wrong picture of Islam and by seeing us behave and act they will see the true meaning of Islam" (Haddad et al., 2009, p. 239). School visits helped to clear misconceptions about Islam, as one student experienced, "I felt I cleared the Muslim name" (Haddad et al., 2009, p.240). Interactions during school visits helped to increase confidence, such as whena student mentioned how she "felt like I made a difference and I did something good in my life" (Haddad et al., 2009, p. 240). Humanizing the "other" was another benefit to authentic school visits, as one student explained, "It taught me of other religions and how much we have in common, not only religiously, but as normal people" (Haddad et al., 2009,p. 241). Another student described how school visits helped to activate personal connections: "It was fun because my school has a large Jewish population, and so many of my classmates wrote the names of the students of your school in Hebrew, too, after having their names written in Arabic" (Haddad et al., 2009, p. 243). School visits provided opportunities for powerful new friendships: "The striking scene at the end of each visit, as students swarm around each other, exchanging email addresses and bittersweet good-byes, does indeed resemble a parting of old friends" (Haddad et al., 2009, p. 244). A teacher who was involved in a school visit described the personal effect of the visit: "I always feel encouraged about the world after spending a day with our children interacting with one another" (Haddad et al., 2009, p. 244). Finally, school visits promoted positive relations between dominant and non-dominant groups, as another student explained, 
We are so thankful to the people who are coming to our school from different churches and organizations to make us feel safe. They are bringing beautiful flowers every day. I want people to respect each other this way. The Muslims respect every religion. We thank the people who have been giving us these gifts for respecting us, too. (Haddad et al., 2009, p. 246)

School visits between Muslim and non-Muslim students and teachers offered a glimpse of what was possible in larger society when two seemingly disparate groups came into contact: "The ripple effect of personal understanding and positive relations that may result from collaboration between dominant and non-dominant groups" (Haddad et al., 2009, p. 246).

\section{Limitations of Collaboration}

However, Shah (2016) argued that although collaboration between different social groups could have a positive impact on students, these shared experiences may not sufficiently provide for the spiritual needs of the Islamic school community:

Commonalities are certainly there and rightly need to be highlighted in today's global and multiply diverse societies for peaceful co-existence. However, the aims of Islamic education extend beyond these commonalities to encompass the spiritual and metaphysical, and that is where liberal education in most Western and secular societies is perceived to be falling short of Muslims' expectations, which poses the question to teachers, educational leaders and policymakers regarding how to accommodate the needs of Muslim citizens within the framework of liberal education. This extension of the aims

of education beyond the individual, material, and corporeal defines the conceptualizations 
and expectations of education and educational leaders/teachers within an Islamic worldview that can be and often are problematic in fitting in with non-Islamic paradigms. (p. 3)

In summary, social constructivism was a suitable theoretical framework to analyze the problem of Islamic school stakeholders' unmet academic, social, and cultural expectations due to its emphasis on making meaning from historical and cultural interactions. Social constructivism was an effective way to analyze how historical and cultural interactions between Islamic school stakeholders and the wider society influence academic, social, and cultural expectations within Muslim schools.

\section{Critique of Social Constructivism}

There are certain assumptions, however, that were examined surrounding social constructivism that hindered understanding the problem of unmet expectations of Islamic school stakeholders. One of the assumptions of social constructivism concerned the meaning that stakeholders made of their expectations for Islamic education. In their discussion on social constructivism, Guba and Lincoln (2007) stated, "we do not believe that criteria for judging either "reality" or validity are absolutist (Bradley \& Schaefer, 1998); rather, they are derived from community consensus regarding what is "real," what is useful, and what has meaning (especially meaning for action and further steps)" (p. 197). I found, using social constructivism as a theoretical framework, that there was a consensus in the Islamic education community regarding academic, social, or cultural expectations. However, just because a community had certain expectations did not necessarily mean that the expectation should have been met. 
Guba and Lincoln (2007) offered a solution to the potential problem concerning social constructivism assumptions and how they may have hindered understanding the problem of unmet expectations of Islamic school stakeholders: "The meaning-making activities themselves are of central interest to social constructionist/constructivists, simply because it is the meaning- making/sense- making/attributional activities that shape action (or inaction). The meaning- making activities themselves can be changed when they are found to be incomplete, faulty (e.g., discriminatory, oppressive, or nonliberatory), or malformed" (Guba \& Lincoln, p. 197). In other words, if there were discriminatory, oppressive, or non- liberatory expectations of Islamic schools, I hope that my findings contributed to the field of Islamic education by exposing potentially repressive elements that existed in the Islamic schools system.

\section{Summary of the Theoretical Framework}

Parents and teachers who were affiliated with Islamic schools had certain social, academic, and cultural expectations. These expectations originated from an Islamic cultural historical context. Parents and teachers acquired their expectations from artifacts such as the Quran and Sunna. Furthermore, stakeholders collaborated with members of the community to interpret, identify and co-create expectations that they wanted their Islamic schools to meet. Parents and teachers affiliated with Islamic schools worked together within their complex communities in a continuous process of creating expectations while navigating shared resources. 
STAKEHOLDER EXPECATIONS OF ISLAMIC EDUCATION

Viewing my topic through the lens of social constructivism, I reviewed the literature regarding the origin of Islamic education and the academic, cultural, and social expectations of teachers and parents affiliated with Islamic schools.

\section{Review of the Research Literature}

Before presenting a review of the literature, I differentiated between various types of Islamic education. Douglass and Shaikh (2004) categorized Islamic education in four ways: 1. Education of Muslims in their Islamic faith (i.e., weekend schools). 2. Education for Muslims which includes the religious and secular disciplines (full time schools that deliver both secular and Islamic education). 3. Education about Islam for non-Muslims (i.e., public school curriculum about Islam). 4. Education in an Islamic spirit and tradition (theoretical conception of Islamic education) (p. 7). In the following literature review, I focused on the two categories that were most relevant to this study on full-time Islamic schools: 1. Education for Muslims that included religious and secular disciplines. 2. Education in an Islamic spirit and tradition.

\section{Background of Islamic Education}

An estimated 32,000 Muslim American students currently attend over 250 Islamic schools nation-wide (Haddad et al., 2009, p. 28). Douglass and Shaikh (2004) discuss the holistic approach to education that Islamic schools pursue:

Like other parochial schools in the America tradition of private schools, Muslim schools carrying out education for Muslims strive to achieve educational excellence, but also to integrate religious values into instruction across the 
STAKEHOLDER EXPECATIONS OF ISLAMIC EDUCATION

curriculum and through service- learning in the family, the school and the community. (p. 9)

Shah (2016) concurred, "the role of education in Islam is to enable individuals to follow the Islamic way of life, to develop the whole person" (p. 24). By highlighting academic, social, and cultural expectations of Islamic school stakeholders, this study explored the holistic approach to education that Muslim schools strive to achieve.

\section{Quran and Haddith as Origins of Islamic Knowledge}

To understand the underlying meaning of Islamic education, it was essential to return to the origins of Islamic knowledge. The two primary sources of the Qur'an (the Muslim Holy Book) and the Haddith (the words and actions of Prophet Muhammad) illuminated the importance that Islam placed on education. The first verses of the Qur'an (Ali, 1994) revealed in the encounter with the Angel Gabriel, as reported by Prophet Muhammad were:

Read! In the name of your Lord and Cherisher, who created; created man out of a clot of congealed blood: Read! And thy Lord is most bountiful; He who taught the use of the pen; taught man that which he knew not. (Qur'an 96:1- 5)

Shah (2016) elaborated on the meaning of Iqra (Read), the first word in the Qur'an: "The debates around the meaning of the word 'iqra', the first word of the revelations and first command to Prophet Mohammed, suggest a range of activities including learning, reciting, exploring and seeking enlightenment" (p. 32). Shah (2016) elaborated on the importance of iqra, "Seeking knowledge, learning, and reflection are permeating themes 
in the Quran. Iqra as the first word of the first revelation to the prophet Muhammad signifies the emphasis on learning and education in Islam" (p. 34).

Another verse in the Quran implored, "O my Lord! Increase me in knowledge" (Qur'an 20:114). According to Shah (2016), this verse illustrated how "knowledge is unlimited and an endless continuity (p. 15). In an authentic Hadith, Prophet Muhammad was reported to have stated, "whoever takes a path upon which to obtain knowledge, Allah makes the path to Paradise easy for him" (At-Tirmidhi, 2007, pp. 50-51). Shah (2016) explained, "the promises to reward learning with higher status here and in the hereafter provide motivation to engage with learning" (p. 34). In another Hadith, Prophet Muhammad was reported to have said, "whoever travels a road seeking knowledge thereby, Allah will cause him to travel one of the roads to Paradise. The angels lower their wings in approval of the seeker of knowledge" (Abu-Dawud, 2008, p. 207). Shah (2016) clarified, "what makes humans the best of creation is that they have been given knowledge by God, and this knowledge equips them with the capacity to develop themselves towards the attributes of God" (p. 25). Hussain and Ashraf (1979) emphasized the responsibilities that come with the attainment of knowledge: "God has bestowed on [human beings], and [human beings] alone among the created things, ability to recognize, understand, and emulate the attributes of God, and realize them in practice in this life" ( $p$. 10). According to Akhtar (1997), the Arabic word for knowledge, ilm, is mentioned 704 times in the Quran (p. 2). The Quran, Hadith, and other authentic Islamic history sources are replete with examples of the value that Islam places on learning. 
STAKEHOLDER EXPECATIONS OF ISLAMIC EDUCATION

\section{To Grow, to Know, and to Discipline the Mind, Body and Soul}

Shah (2016) discussed three terms from the Quran and Hadith that encapsulated the meaning of Islamic education: Tarbiyah, ta'lim, and ta'dib. Tarbiyah means 'to increase and grow," ta'lim means "to know," and ta'dib means "the disciplining of the mind, body, and soul" (p. 32). Iqbal (1996) explained, "these three terms, tarbiyah, ta'lim and ta'dib, have been most commonly used to define education in Islamic thought, which taken together might convey the meaning and scope of education in Islam, both formal and informal" (p. 50). Al-Taftazani (1986) elaborated on the meaning of tarbiya, to grow, within the context of knowledge: "Education would mean the gradual bringing of something to completeness, perfection, or maturity" (p. 67). Halstead (2004) explained that $t a$ 'lim, to know, "refers to the imparting and receiving of knowledge, usually through training, instruction or other form of teaching” (p. 522). Al-Attas (1979) described ta'dib, the disciplining of the mind, body, and soul, as "the process of character development and learning a sound basis for moral and social behavior within the community and society at large” (pp. 2-4). The intersection of tarbiyah, ta'lim, and ta'dib highlighted the importance of learning for the individual as well as society. Abuarqub (2009) emphasized the critical role that knowledge played in the community: "While knowledge is needed to fulfil religious and spiritual responsibilities, it is also highly important for achieving social and economic development, for the wellbeing of the community, and for achieving social harmony, freedom and human rights" (pp. 8-9). Shah (2016) summarized the moral purpose of knowledge: "Knowledge is to create a society of good human beings and good citizens" (p. 16). 
STAKEHOLDER EXPECATIONS OF ISLAMIC EDUCATION

The Spread of Islamic Educational Centers World-Wide

The Islamic educational institutions that flourished across Asia, Africa, and Southern Europe with the advent of Islam in the seventh century represented the importance that Islam placed on knowledge, growth, and disciplining the mind, body and soul. Hilgendorf (2003) elaborated,

At least 60 major centres of learning spanned the Islamic Empire from Baghdad and Isfahan in the East to Cordoba in the West that courted the wisest and most influential leaders of human knowledge. Muslim scientists, mathematicians, astronomers, physicians, artists, architects, philosophers, legal scholars, writers, and others made profound contributions toward the advancement of civilization that continue to impact our world. (p. 619)

Due to the emphasis that Islam placed on learning, hardly a discipline existed that was left untouched by the hands of Muslim scholars and the influence of Islamic institutions. Al-Attas (1977) further elaborated on Muslim contributions to the world's art and sciences in his keynote address in the First World Conference on Muslim Education:

Muslim works on science, philosophy and other fields were translated into Latin, particularly from Spain and enriched the curriculum of the West. The Muslims passed to the experimental method of science. The system of Arabic notation and decimals was introduced to the West. Their translated works, particularly those of men such as Avicenna in medicine, were used as texts in classes of higher education far into the middle of the 17th century. They stimulated European thought, reacquainted it with the Greek and other classical cultures and thus helped 
STAKEHOLDER EXPECATIONS OF ISLAMIC EDUCATION

bring about the Renaissance. They preserved Greco Persian thought when Europe was intolerant of pagan cultures. European students in Muslim universities carried back new methods of teaching. They contributed knowledge of hospitals, sanitation and food to Europe.

While Europe was enduring its Dark Ages, the Islamic world was thriving during its Golden Age. Alexakos and Antoine (2005) described the effect of the Islamic Golden Age on the Dark Ages in Europe:

If not for the effort of the potpourri of scholars and scientists at the employment of these caliphs, much of the work of these cultures would have been irretrievably lost in Europe over the long period of the Dark Ages. The immediate effect was a great stimulus to culture and science — the Golden Age of Islam. During its height, in virtually every area, the work of Arabic scientists was the most advanced in the world. (p. 37)

The scarcity of information that characterized the Dark Ages of Europe contrasted the wealth of knowledge that illuminated the Golden Age of Islam. Douglass and Shaikh (2004) summarize the far-reaching influence of the Islamic world:

The humanities flowered with the development of Muslim civilization. Scientific knowledge was built upon the foundation of practical knowledge of the Arabs in seafaring, navigation and astronomy, trade, animal husbandry and agriculture. Caliphal patronage supplied funding and the development of Islamic law provided motivation for scholars to set high standards for time-keeping and calendars, accurate orientation of the direction of worship toward the Ka'bah, and 
STAKEHOLDER EXPECATIONS OF ISLAMIC EDUCATION

calculation of inheritance, weights, and measurers. Curiosity, geographic access, and ample means supplied the dynamic for the massive translation, absorption, development and dissemination of knowledge of all kinds. The timely arrival of papermaking technology from China provided additional impetus to this dynamism. The flourishing of this literate tradition resulted in the formation of educational institutions that advanced ideas about Islamic education far beyond its rudimentary beginnings, and that continue to shape such ideas today. (p. 13)

This depth and breadth of Islamic intellectual curiosity and achievement laid the foundation for contemporary Islamic institutions that strive to emulate and build upon the Islamic learning centers of the past. Cheddadi (2000) elaborated on the advanced educational system of pre- industrial Muslim societies:

The educational system in Muslim societies was without a doubt one of the most extensive and most developed of all those prevailing in pre-industrial societies...more flexible and less hierarchically organized structures. The body composed of scholars and the literati was open, non-centralized, non- hereditary, non-exclusive, with a fluid organization that implied no formal hierarchy thus giving rise to a relatively broad education and teaching system that in many ways prefigured our modern systems. (p. 1)

In many ways, the educational system in pre-industrial Muslim societies was ahead of its time in terms of its egalitarian, inclusive, and accessible approaches to learning. In fact, these were some of the qualities that teachers and parents in my study expected from their Islamic schools. 


\section{Expectations of Parents and Teachers}

With the importance that Islam placed on education established, I proceed with a review of the literature that highlighted the academic, social, and cultural expectations which parents and teachers anticipated from Islamic schools. Shah (2016) stated, "the issue of Muslim identity in contemporary societies, concerns about educational achievement of Muslim learners, racism and Islamophobia and socio-political alienation experienced by Muslims emerge as significant factors shaping their needs and expectations of education" (p. 10).

Elbih (2012) described a study involving six all-girls schools that highlighted the multiple and varied expectations of Islamic school stakeholders. The case study revealed that parents expected Islamic schools to protect the Islamic character of their children: "Parents argued the main purpose of Islamic schools was to preserve Islamic values and identity" (p. 159). Teachers in his study expected Islamic schools to instruct students about the central tenets of Islam: "Teachers saw the schools as pedagogical mechanisms to educate Muslim students about Islamic epistemology” (p. 159). In the following literature review, I discussed each stakeholder individually, starting with parents, and focus on their academic, social, and cultural expectations of Islamic schools.

\section{Importance of Parents in Islam}

Parents, especially mothers, are highly honored in Islam. A well-known verse in the Quran implored Muslims to show gratitude first to God, then to parents: 
And We have enjoined on man (to be good) to his parents. In travail upon travail did his mother bear him, and in two years was his weaning. Show gratitude to Me and to thy parents; to Me is thy final goal (Quran 31:14).

Another verse in the Quran beseeched Muslims to be kind to their parents:

Thy Lord hath decreed that ye worship none but Him, and that ye be kind to parents. Whether one or more attain old age in thy life, say not to them a word of contempt, nor repel them, but address them in terms of honor. And out of kindness, lower to them the wing of humility, and say, "My Lord! Bestow on them Thy Mercy, even as they cherished me in childhood. (Quran 17: 23-24) Merry (2007) emphasized the role that parents played in the educational outcome and identity of children: “A learning environment culturally (or religiously) consonant with parents is more likely to produce healthy learning outcomes for young children and is more likely to foster a firmer sense of self' (p. 78).

In Merry’s (2005) study, in which dozens of parents from the Midwest were interviewed about what they hoped to gain by enrolling their children in Islamic schools, parents listed their religious, academics, and cultural expectations. Merry (2005) stated, "Muslim parents who seek out Islamic schools are chiefly concerned that their children be schooled in a total Islamic environment that provides a strong cultural and religious identity and the means of integrating all learning through an Islamic point of view" (p. 378). Shah (2016) explained, "Islamic schools are increasingly being seen by many parents as offering an option for providing appropriate Islamic environment conducive to fostering Muslim identity and improving educational achievement” (p. 142). Parents' 
expectation to teach the standard curriculum from an Islamic perspective was a common theme in several studies related to Muslim schools.

\section{Parents' Academic Expectations}

Regarding academic expectations, Merry (2005) found that parents put a high premium on the academic excellence of their children who attended Islamic schools: "Muslim parents are seeking to secure for their children the highest academic formation that they can afford" (p. 378). Shah (2016) stated, "low achievement of Muslim children in many state schools and concerns about the impact of school culture on community culture, values and identity are forcing many Muslim parents to consider alternative educational provisions" (p.139). Haddad et al. (2009) echoed the priority that parents placed on high quality education for their children: "They are extremely eager that their children receive the best education possible and want to make sure that Muslim schools have high educational standards" (p. 11). Shah (2016) stated that parents "expect schools to promote a respect for Muslim identity and for Islamic social and moral values considered essential for their social structure, and to enhance awareness of Islamic history and teachings through the curriculum to promote inclusion and educational engagement" (p. 147). Modern-day Muslim parents who sent their children to Islamic schools appeared to reflect a similar reverence for education as the early Muslims who were implored by Prophet Muhammad to "acquire knowledge and impart it to the people" (At- Tirmidhi, 1983). According to Shah (2016) parents' academic expectations were largely met by Islamic schools: "Compared to multicultural state school located in the same social and 
STAKEHOLDER EXPECATIONS OF ISLAMIC EDUCATION

economic areas, independent Islamic schools, in spite of meagre resources, excel in student achievement” (p. 150).

\section{Parents' Cultural Expectations}

Concerning cultural expectations, Shah (2016) explained the role that parents played in their children's education: "Children need to be brought up as members of the relevant cultural communities to develop their sense of belonging and social responsibility, and parents have the right to make school choices and relevant decisions for their children who are too young to decide themselves" (p. 157). Merry (2005) discovered that parents worried about their children losing touch with important traditions such as speaking the home country language, dressing modestly, and respecting authority: "Muslim parents — particularly recent immigrants — are very interested to have their children learn about their cultural heritage" (p. 378). These parents may have enrolled their children in Islamic schools as a way of reinforcing customs from their home country. Elbih (2012) stated, "the fear of peer pressure, assimilation, and identity loss among Muslim students lead their parents to consider alternative education, either homeschooling or Islamic schools" (p. 163). Shah (2016) explained,

The schools, as another site of cultural learning, are often criticized by the Muslim community for leading the youth away from their culture and values. The state schools' environment is critiqued for not being in consonance with their values and culture, driving many parents towards other alternatives for educating their children in an Islamic environment to foster faith identity. (p. 140) 
Such parents may have envisioned Islamic schools as promoters of home country cultural values as well as protectors from total assimilation into American culture.

Merry (2005) argued, "parents want to keep their children 'uncorrupted' from the secular society and feel that the only option available to them is an Islamic education" ( $\mathrm{p}$. 379). Shah (2016) elaborated:

The aspiration among the Muslim parents to educate their children in Islamic teachings and values is motivated by a desire to be recognized as Muslims but more importantly to protect their children from what they see as the threat of Western culture and values to their family structures and networks, their specific traditions and practices and their group identity. Muslim parents increasingly are expressing concerns regarding the effects of host culture and its permissive values on their children. (p. 151)

Merry (2005) discovered several other parental expectations of Islamic schools such as the avoidance of racism, the desire for accurate representation of culture and religion, a demand for higher academic expectations for their children, a need for greater discipline, an emphasis on morality, and a wish to protect their children from negative influences of secular society. Shah (2016) summarized the reason for parental support for Islamic education:

A whole range of factors and some complex interacting elements are contributing to the enhanced support for faith schools from the parents and community. This support is to a certain extent embedded in a desire for their children to learn more about their religion and its teachings, to encourage the development of community 
STAKEHOLDER EXPECATIONS OF ISLAMIC EDUCATION

identity and religious values among children and to promote their upward social mobility through improved educational achievement. (p. 154)

Islamic schools were under enormous pressure to deliver on these heavy demands of Muslim parents.

\section{Importance of Teachers in Islam}

Along with parents, teachers were also highly regarded in the Islamic tradition. Shah (2016) stated, "Mu'allim (teacher) also has the authority and status of a parent, the highest authority within the Islamic social system. Shah (2016) explained,

The Islamic discourse of God as teacher and the association of knowledge and teaching with God and Godly attributes raises teaching and leading to the level of the highest- status activity, and informs the theoretical constructions of Islamic philosophy of educational leadership. (p. 48)

Just as paradise is at the feet of mothers in the Islamic tradition, teaching is next to Godliness. Shah (2016) elaborated on the critical role of teachers in Islam: "Association of parental authority with Mu'allim or teacher is indicative of the utmost respect and obedience accorded to them by the religion, and along with claims of knowledge, this emerges as a powerful source of the teacher's authority, underpinning the relevant conceptualizations and practices" (p. 49).

Teachers are held in such high esteem in Islam that parents entrust their children to Islamic school teachers to safeguard and nurture as if the child was their own.

\section{Teachers' Expectations of Islamic Education}


Teachers in Islamic schools had their own set of demands. In Memon's (2011) study, a variety of seasoned, less experienced, and lead teachers from four Islamic schools in Toronto discussed their expectations of Islamic education with a research team made up of educational consultants and professors from three Islamic organizations in Toronto. Memon (2011) identified seven expectations that teachers expressed during interviews in focus groups lasting for two hours in the fall of 2009: a comparative study of teaching pedagogies, training on how to teach effectively from an Islamic perspective, learning how to manage the classroom using a Prophetic pedagogy, instruction on integrating Islamic values into the learning environment, guidance on teaching in a diverse Islamic environment, training on integrating the Islamic curriculum, and coaching on how to help students gain confidence as they struggle with their identity as Muslim youth growing up after 9/11.

\section{Teachers' Expectations to Make Pedagogical Distinctions}

Regarding teacher expectations of a comparative study of teaching pedagogies, Memon (2011) stated, "in the design of the program, there should be something that could compare the differences and also the similarities between public school and Islamic schools systems. There should be something to define how Islamic schools will be different from others" (p. 291). Memon's study revealed that teachers in Islamic schools desired training which resulted in their ability to make distinctions and choices among various pedagogies. Shah (2016) explained how Islamic schools differed from public schools: 
STAKEHOLDER EXPECATIONS OF ISLAMIC EDUCATION

Besides improving educational achievement and combating racism, Muslim faith schools also offer some knowledge of the history of Islam and Muslims, their achievements and their contributions to knowledge and society. They introduce the learners to the Muslim role models from the history of Islam to inspire and motivate them. (p. 151)

\section{Teachers' Expectations to Teach from an Islamic Perspective}

With respect to the expectation of receiving training on how to teach effectively from an Islamic perspective, Memon's (2011) study suggested that teachers appreciated some formal guidance on how to model the character of Prophet Muhamad in the classroom: "Teachers have often mentioned the need to better embody the practices of the Prophet Muhammad in all aspects of life but related to the principles by which he taught in particular" (p. 291). Shah (2016) explained, "for Muslims, the ultimate model of leadership is the prophet Mohammad, as verified in the Quran: 'Verily the best model for you is the Holy Prophet' (33:21)" (p. 46). As a teacher in the study stated, "having a nice combination of teaching strategies plus our Prophet's way of being kind and caring (peace and blessing upon him), that is most important" (p. 291). The way in which Islamic school teachers tried to emulate the principles and practices of Prophet Muhammad in the classroom was an example of the historical connection with Islamic education that Muslim teachers expected to forge at their own schools.

\section{Teachers' Expectations to Manage Classroom with Prophet as Example}

Concerning the expectation of learning how to manage the classroom using a Prophetic pedagogy, Memon (2011) addressed the issue of discipline in Islamic schools: 
"A number of Islamic school teachers mentioned the need to embody examples of his wisdom (hikma) when wanting to motivate and inspire students. This includes addressing misbehavior or correcting inappropriate actions with mercy (rahma)" (p. 292). Rather than using punitive methods of discipline, the teachers in Memon's (2011) study preferred to imitate the patience and compassion that Prophet Muhammad was reported to have demonstrated toward his followers, particularly the children. Prophet Muhammad's affection for children was well- documented in several authentic Hadith. For example, a Hadith in at-Tirmidhi (2007) described Prophet Muhammad's response to a person who did not kiss his children: "Whoever shows no mercy, he will be shown no mercy" (p. 32). Another Hadith in Khan (1997) described how Prophet Muhammad regularly allowed children to climb on his back while prostrating during prayer: "The Prophet came out toward us, while carrying Umamah, the daughter of Abi Al-As over his shoulder. He prayed, and when he wanted to bow, he put her down, and when he stood up, he lifted her up" (p.30). Because Prophet Muhammad was an impoverished orphan by the time he was six (Armstrong, 2006), he understood the potential vulnerabilities of childhood first hand.The teachers in Memon's (2011) study wanted to exemplify Prophet Muhammad's tenderness toward children in their own teaching practice.

\section{Teachers' Expectations to Integrate Islamic Values into Classroom}

Relating to the expectation of learning how to integrate Islamic values into the learning environment, Memon (2011) recognized that teachers have differing ideas about the purpose of Islamic education. As one teacher in the study stated, "when teachers are working at Islamic schools, not everybody is at the same level. Not everybody is working 
to get towards the same purpose" (p. 293). Shah (2016) explained, "The issue of "whose values' and 'what values' becomes problematic" (p. 59). "Riley et al. (2004, p. 9) attend to the issue by discussing the extent to which the leader's values and beliefs need to be harmonized for effectiveness. The emphasis on equality and justice in Islam (the Quran 49:13) aims at inclusion and embracing diversity. This requires understanding and recognition of the values of all diverse groups" (p. 59). Memon (2011) argued that infusing a shared sense of purpose in an Islamic school was a critical step toward integrating Islamic values into the learning environment: "If that [purpose] is instilled during the course, then it may help the functioning of the school because (then) the teachers are all on the same level” (p. 293). Once teachers acquired a shared sense of purpose, Memon (2011) stated that they are in a better position to integrate Islamic values into the learning environment. Another teacher in his study stated, "intention should be cultivated through reinforcing Islamic values and a Prophetic way of teaching during the programme" (p. 293). A final teacher added, "integration of Islamic values and the values of teaching are essential" (p. 293). Memon (2011) summarized, "essential to an Islamic pedagogy is reframing the purpose of learning from an Islamic perspective" (p. 293).

\section{Purpose of Learning from an Islamic Perspective}

The purpose of learning from an Islamic perspective, according to some Islamic school educators in Memon's (2011) study, was the preservation of peace and justice, which was the duty of all Muslims: "Some Muslim educators have articulated this through the Islamic concept of khalifat-Allah fil-ard (vicegerent of God on earth) whose responsibility it is to uphold peace and justice" (p. 292). Shah (2016) explained, 
STAKEHOLDER EXPECATIONS OF ISLAMIC EDUCATION

The role of Islamic education is perceived to give meaning to life and enrich it, instilling discipline and preserving human values, strengthening and advancing human societies. The argument is explicit that education in Islam should aim to prepare human beings for leading a life of 'righteousness' in a social context. The perceptions contribute to enhanced expectations of Muslim learners and communities of education in diverse contexts. (p. 24)

Teachers who had expectations of integrating Islamic values into the learning environment may have benefitted by incorporating elements of social justice into the curriculum.

\section{Teachers' Expectations of Guidance in Navigating Diversity}

Pertaining to teachers' expectations of guidance on teaching in a diverse Islamic environment, Memon (2011) emphasized the need for a clear school vision while, at the same time, accepting the diversity of thought that permeated Islamic schools:

Teachers across the schools agreed that Islam must be taught with some semblance of balance and sensitivity when addressing cultural, sectarian, and ideological differences within Muslim communities and Islamic history. This could be achieved they said through exploring the multiple types of Islamic schools, curriculum frameworks, and instructional methods without imposing one type as definitively 'Islamic'. (p. 293)

Blackwell-Flanagan (2012) argued, “the lack of teachers' cultural knowledge of self as well as diverse groups hinders achievement, creates a divide in the classroom between 
students and teachers, and affects students' engagement" (p. 312). Shah explained the importance of understanding how to teach in a diverse educational environment:

In the emerging multi-cultural, multi-faith societies, the need to enhance knowledge and understanding of diverse cultural and faith communities is significant for improving educational achievement for all and for maintaining societal stability and harmony as well as for ensuring social justice and equal opportunities. This places tremendous responsibility on educational leaders who are expected to provide not just the future work force but also the future citizens for global societies believing in diversity of values and respect for plurality. (p. 181)

Islamic schools could work toward meeting teachers' expectations of guidance on teaching in a diverse Islamic environment by hiring teachers and enrolling students whose backgrounds reflected the vast array of perspectives that permeated the Islamic world.

\section{Teachers Expect Training on Integrating Islamic Curriculum}

Regarding the expectation of training on how to integrate the Islamic curriculum, Memon (2011) distinguished between teaching subjects such as science and history from an Islamic perspective as opposed to simply adding an appendage in the curriculum that addressed a few Muslim contributions to society: "This would imply a curriculum that upholds the standard, depth, scope, and sequence of provincially approved curriculum yet developed with the content and written from a perspective that centers on Islamic epistemology and across subjects" (p. 294). Shah (2016) explained, "an educational 
leader must be a constant seeker and giver of knowledge, who in the tradition of the prophets, is bestowed with the trust and responsibility to lead towards the integrated development of the learners' soul, mind and body" (p. 52).

\section{Teachers' Expectations of Coaching on Students' Muslim Identity}

Finally, Memon (2011) addressed teachers' expectations of getting coached on how to help students gain confidence as they struggled with their identity as Muslim youth growing up after 9/11. Otherwise, as Shah (2016) warned, "teachers may become instruments of discrimination when they fail to deal with racism effectively in the schools and classrooms" (p. 149). A teacher in the study stated that teachers "need to be empowered themselves to then make the kids believe that anything is possible. Not only can they do whatever they want, but that they are responsible for change" (p. 295). Other teachers in the study indicated that instruction on critical media literacy would help them to navigate the negative portrayal of Muslims that existed in newspapers, television, social media, and radio: "It was also suggested that there be critical media literacy taught to Islamic school teachers on how to respond to the popular misunderstandings and misconceptions about Islam and Muslims" (Memon, 2011, p. 295). Shah (2016) stated, "media has added to the complexity of the situation through portrayals of Islam as barbaric, irrational, primitive and sexist, and more recently through implied associations with terrorism" (p. 110). Students could benefit directly from critical media literacy by helping them to understand how and why Muslims are misrepresented, leading them to develop a more centered Islamic identity. 
STAKEHOLDER EXPECATIONS OF ISLAMIC EDUCATION

Summary of Literature Review

The literature review described the research on academic, social, and cultural expectations of Islamic school stakeholders using social constructivism as a theoretical framework, which emphasized that people create meaning in their lives through their interactions with one another. Overall, the literature review suggested that stakeholders acquired their various academic, social, and cultural expectations of Islamic schools from the historical and cultural norms that were socially constructed within the Muslim community.

The research methods in the literature review consisted of interviews and observations, which were appropriate for qualitative studies. However, an important component was missing from the methodological literature on Islamic education- the voice of the researcher. Sirin and Fine (2008) explained:

Studies on Muslim students' education have relied predominantly on interviews. Studies which have used both interview and observation methods may lack critical engagement with their own and the participants' assumptions, biases, and superficiality. In sum, the research on Muslim education needs to further acknowledge its epistemological and methodological limitations, use multiple methods and reflexivity, where the voices of the researchers are examined as critically as those of teachers' and students'. (Niyozov \& Pluim, 2009, p. 667)

In the following chapter on methodology, I explained how I planned to critically examine my own assumptions, biases, and superficiality, as well as those of the 
stakeholders that I interviewed, in order to reveal the origin, complexity, and implication of stakeholder expectations. 
STAKEHOLDER EXPECATIONS OF ISLAMIC EDUCATION

Chapter 3: Methods

In Chapter 1, I described the social, cultural, and academic expectations of parents and teachers in Islamic schools. I explained how the origin of Islamic education related to modern day Islamic schools. In the United States, Islamic schools may not be meeting all of the expectations of some teachers and parents for a variety of reasons. I used two research questions to study this problem:

1. What are the academic, social, and cultural expectations that parents and teachers have of their Islamic schools?

2. To what extent are Islamic schools meeting the expectations of parents and teachers?

The purpose of this study was to gain a deeper understanding of what parents and teachers expected from Islamic schools in order to help these schools to better meet the expectations of primary stakeholders, specifically parents and teachers.

In Chapter 2, I reviewed the literature about the academic, social, and cultural expectations of parents and teachers. I explained my theoretical framework, social constructivism (Vygotsky, 1978; Bruner, 1978; Dewey, 1938), which highlighted the interdependent nature of human understanding whereby individuals collaborate to construct meaning. I described the connection between social constructivism and Islamic education using Engeström's (1987) cultural-historical activity theory (CHAT), an activity system that illustrated the multiple perspectives of stakeholders working collaboratively within a dynamic Islamic community. 
STAKEHOLDER EXPECATIONS OF ISLAMIC EDUCATION

I concluded Chapter 2 by explaining the methods I used to conduct the study. I used a qualitative approach as my method of research (Creswell, 2013). Phenomenology was the approach that I used to describe the shared experiences of teachers and parents (Creswell, 2013). To answer my research questions, I interviewed teachers and parents at an Islamic school on the West Coast using a preliminary questionnaire, a questionnaire follow- up, and interview questions to triangulate the study (Vogt, Gardner, and Haeffele, 2012).

In this chapter, I delineate the methods I used to study the social, academic, and cultural expectations of teachers and parents in Islamic schools. In addition, I describe the extent to which these expectations are being met.

\section{Research Methods}

Since the purpose of my research was to understand what stakeholders expect from Islamic education, I used a qualitative approach as my method of research. Maxwell (2013) described several goals of qualitative studies:

- Understanding the meaning, for participants in the study, of the events, situations, experiences, and actions they are involved with or engaged in,

- Understanding the particular contexts within which the participants act, and the influence that this context has on their actions, and

- Understanding the process by which events and actions take place (p. 30). 
Maxwell's (2013) qualitative goals coincided with the goals of this study: As a

researcher, I wanted to understand the meaning that teachers and parents attributed to their Islamic school experience. Additionally, I wanted to understand the context that influenced teachers' and parents' expectations of Islamic education. Lastly, I am interested in the process that stakeholders underwent that led up to their expectations. Maxwell (2013) elaborated on a distinction between quantitative and qualitative researchers:

Quantitative researchers tend to be interested in whether and to what extent variance in $x$ causes variance in $y$. Qualitative researchers, on the other hand, tend to ask how $x$ plays a role in causing $y$, what the process is that connects $x$ and $y$. (p. 31)

In other words, a qualitative design was appropriate for this study due to an emphasis on how stakeholders acquired expectations for Islamic education, as opposed to a quantitative design which would have emphasized correlations between stakeholder expectations and Islamic education.

My intent as a researcher was to understand what Islamic education meant to stakeholders. Creswell (2013) stated, “the researcher's intent, then, is to make sense of (or interpret) the meanings others have about the world" (p. 25). Incidentally, the understanding that I gained regarding stakeholder expectations was influenced by my own personal and professional involvement as a long-term parent and teacher at an Islamic school. Creswell (2013) stated, "the researchers make an interpretation of what 
they find, an interpretation shaped by their own experiences and background" (p. 25).

The interpretation of my findings was influenced by my extensive experience with Islamic education as well as by my cultural and educational background. Qualitative research lent itself to this type of interpretive research.

Just as a qualitative design was an appropriate fit for my research, phenomenology was a well-suited approach for my study. Creswell (2013) described how constructivism, the theoretical framework I used for the study, and phenomenology, went hand in hand: "We see the constructivist worldview manifestin phenomenological studies, in which individuals describe their experiences" (p. 25). Krathwohl (2009) elaborated to the connection between social constructivism and phenomenology:

That 'something' is the view of some qualitative researchers who hold symbolic interactionist or phenomenological points of view. Although not denying the role of culture, they [qualitative researchers] emphasize the meanings persons attach to others and to the things that surround them- symbolic interaction. That is, people act according to the things that they attribute to things and persons; their reality is socially constructed. From this viewpoint, to reach a full understanding of the purpose of a person's behavior it is necessary to see the world through their eyes. (p. 242)

Here, Krathwohl (2009) contrasted the phenomenological points of view with the positivist epistemological position in which reality is waiting to be discovered. On the contrary, this study contained as many realities as there were stakeholders. A 
phenomenological approach allowed me to understand stakeholder expectations by seeing the world, as much as possible, through the eyes of the participants.

Furthermore, Creswell (2013) elaborated on the collective nature of a phenomenological study, explaining how participants made sense of a shared experience: "A phenomenological study describes the common meaning for several individuals of their lived experiences of a concept or a phenomenon" (p. 76). The phenomenon, in the case of my study, was the shared experiences of teachers and parents of Islamic schools. I collected data from Islamic school stakeholders and described the essence of their experience - what they experienced, how they experienced it, what their expectations were as a result of their experiences, and the extent to which Islamic schools were fulfilling these expectations.

Seidman (2013) identified four themes that clarified a phenomenological approach to interviewing: the temporal and transitory nature of human existence; subjective understanding; lived experience as the foundation of phenomena; and emphasis on meaning and meaning in context (pp. 16-17). With respect to the temporal and transitory nature of human existence, Seidman (2013) explained, "in the process of asking participants to reconstruct and reflect on their experience, researchers using a phenomenological approach ask participants to search again for the essence of their lived experience" (pp. 16-17). Similarly, using a phenomenological approach to interviewing, I asked parents and teachers to return to the roots of their experiences with Islamic education to gain insight into the origin of their expectations. Regarding subjective understanding, Seidman (2013) argued, 'the goal of researchers' using a 
phenomenological approach to interviewing would be to come as close as possible to understanding the true 'is' of our participants' experience from their subjective point of view" (p. 17). While it was impossible to completely relate to the experiences of teachers and parents, a phenomenological approach to interviewing enabled me as a researcher to come as close as possible to identifying with their educational expectations. Concerning lived experience as the foundation of 'phenomena,' Seidman (2013) clarified, “by concentrating on the details of participants' experiences, interviewers strive as best as possible to guide their participants to reconstitute their lived experience" (p. 17). As a researcher using a phenomenological approach to interviewing, my challenge was to convert the lived experiences of teachers and parents into a written expression of their expectations. Pertaining to the emphasis on meaning and meaning in context, Seidman (2013) reasoned, "by asking participants to reconstruct their experience and then reflect on its meaning, interviewers encourage participants to engage in that 'act of attention' that then allows them to consider the meaning of a lived experience" (p. 19). The meaning that teachers and parents extracted from their experiences impacted the expectations that were generated. Finally, relating to meaning in context, Seidman (2013) justified, "interviewing allows us to put behavior in context and provides access to understanding their action" (p. 19). Using a phenomenological approach to interviewing enabled me as a researcher to contextualize the behavior of teachers and parents which in turn allowed me to understand their educational expectations.

In addition to surveying and interviewing members of the Islamic school community, I also explored a variety of venues in my quest to discover responses to my 
research questions, including examining Islamic school websites, and analyzing current research studies on Islamic education in the United States. I investigated my research questions within the Islamic school community because parents and teachers within the community had first-hand experience with Islamic education: parents were heavily invested in their child's education and had high educational expectations, and teachers had devoted their professional and much of their personal lives to Islamic education and provided their own unique insights regarding their professional and personal expectations.

\section{Participants}

I recruited ten participants from a full time Islamic school on the West Coast to interview, including five middle school $\left(6^{\text {th }}-8^{\text {th }}\right.$ grades $)$ teachers and five parents of middle school students. I included a diverse sample of participants who varied in terms of experience, gender, education, and cultural background in order to incorporate a variety of voices in the study, as illustrated in the tables below:

Table 1

Purposeful Selection of Participants-Teachers

\begin{tabular}{|l|l|l|l|l|}
\hline Teacher Participant & Gender & Education background & Cultural background & Teaching experience \\
\hline 1.Khadija & Female & Graduate degree & Europe & 6+ years \\
\hline 2.Aisha & Female & Bachelor degree & Middle East & $6+$ years \\
\hline 3.Azrah & Female & Graduate degree & North Africa & $6+$ years \\
\hline 4. Sawda & Female & Bachelor degree & United States & 6+ years \\
\hline 5.Zaynab & Female & Bachelor degree & Middle East & $6+$ years \\
\hline
\end{tabular}


Table 2

Purposeful Selection of Participants-Parents

\begin{tabular}{|l|l|l|l|l|}
\hline Parent Participant & Gender & Education background & Cultural background & Parent experience \\
\hline 1.Fatima & Female & High school & United States & 3 children \\
\hline 2.Abdul & Male & Graduate degree & North Africa & 3 children \\
\hline 3.Ruqayah & Female & Bachelor degree & Middle East & 5 children \\
\hline 4.Mariam & Female & Bachelor degree & Asia & 2 children \\
\hline 5.Aminah & Female & High school & Africa & $5+$ children \\
\hline
\end{tabular}

Maxwell (2013) explained the significance of this type of purposeful selection of participants: "Selecting those times, settings, and individuals that can provide you with the information that you need to answer your research questions is the most important consideration in qualitative selection decisions" (p. 97). Maxwell (2013) elaborated on the goals for purposeful selection: to achieve representativeness or typicality of the settings and individuals selected; to adequately capture the heterogeneity in the population; to deliberately select individuals that are critical for testing your theories; to establish particular comparisons to illuminate the reasons for differences between settings or individuals; and to choose participants that will allow you to answer your research questions. Seidman (2013) explained, "the goal would remain to sample purposely the widest variation of sites and people within the limits of the study" (p. 56). The purposeful 
selection of middle school teachers and parents of middle school students, all from a variety of backgrounds, enabled me to find answers to my research questions.

In order to conduct a study that was as fair and balanced as possible, I selected members from an Islamic school on the West Coast that was unfamiliar to me. Seidman (2013) explained the drawback of interviewing participants that interviewer had known previously:

Instead of exploring assumptions and seeking clarity about events and experiences, they tend to assume that they know what is being said. The interviewer and the participant need to have enough distance from each other that they take nothing for granted. (p. 46)

Interviewing participants from an unfamiliar Islamic school allowed me to explore assumptions about their experiences with Islamic education and seek clarity about their expectations.

I contacted the principal of an Islamic school on the West Coast by phone to ask permission to conduct a study at the school. We agreed to meet at the Islamic school to get acquainted and discuss the study in more detail. The school, a two- story building containing several small classrooms, was located on a busy street with businesses on each side. I was greeted at the door by the principal who led me to her office just as classes were ending and a stream of middle school students passed by. The principal received me warmly and professionally, giving me her full attention and listening carefully to the details of my request. After summarizing my study, the principal asked me to write a 
letter to the school board that outlined the key points of the study. After a week or so, the principal sent me an email stating that the school board had approved the participation of their teachers in my study, at which point I sent letters of consent to the principal to distribute to teachers to sign and return to me. The principal and I agreed that she would send letters of consent directly to the teachers and parents affiliated with the school to begin the recruiting process. The principal, who also taught at the Islamic school, agreed to participate in the study as a teacher participant. After receiving signed letters of consent from several teachers and parents, I recruited participants by sending a preliminary fact-finding questionnaire to approximately ten respondents (see Appendix A). After receiving the responses on the questionnaire, I sent a follow-up questionnaire to the ten respondents which probed more deeply into the three areas under investigation: the social, academic, and cultural expectations of stakeholders (see Appendix B). Next, I contacted the ten potential participants by phone and email to ask them to take part in indepth interviews lasting for around ninety minutes each (see Appendix C). Seidman (2013) explained the reason for allocating ninety minutes for each interview:

An hour carries with it the consciousness of a standard unit of time that can have participants 'watching the clock.' Two hours seems too long to sit at one time. Given that the purpose of this approach is to have the participants reconstruct their experience, put it in the context of their lives, and reflect on its meaning, anything shorter than 90 minutes for each interview seems too short. (pp. 23-24)

These three points of data (Preliminary Questionnaire, Questionnaire Follow-up, and the Interview Questions) helped to triangulate the study. Vogt, Gardner, and Haeffele (2012) 
defined triangulation as "the use of several means to examine the same phenomenon (p. 111). Vogt et al. (2012) further explained that triangulation "will broaden your understanding of the phenomenon of interest, whether by confirming a finding or by contradicting it—or by discovering new variables. In other words, the results of triangulation can improve your research" (p. 111). The use of the Preliminary Questionnaire (see Appendix A), the Questionnaire Follow-up (see Appendix B), and the Interview Questions (see Appendix C) helped to increase my understanding of stakeholder expectations which, in turn, helped to improve my research.

I identified the ten initial participants by creating a list of stakeholders from the school who fell into one or both of the participant groups (parents and teachers). Seidman (2013) asked researchers to consider what constituted a reasonable number of participants: "Are there sufficient numbers to reflect the range of participants and sites that make up the population so that others outside the sample might have a chance to connect to the experiences of those in it?" Furthermore, Seidman (2013) asserted that researchers have reached a saturation point when "he or she is no longer learning anything new" (p. 58). Along with sufficiency and saturation, Seidman (2013) argued that time, money and resources are also important considerations when researchers decided on the number of participants to interview: "The criteria of sufficiency and saturation are useful, but practical exigencies of time, money and other resources also play a role, especially in doctoral research" (p. 58). Considering the relatively small number of teachers and parents affiliated with the Islamic school under study, and my limited time and money to 
spend on the study, I determined that ten participants was a sufficient number of teachers and parents to contact, leading me close to a saturation of information.

I documented the potential participants who appeared to be a good fit for the study. Seidman (2013) recommended to "keep a record of those who seem most suitable, noting their key characteristics that are related to the subject of the study" (p. 52). Examples of key characteristics included a balance between male and female participants, diversity in ethnic backgrounds, range of time spent in respective roles, variety of satisfaction rates, assortment of expectations, and varying degrees of expectations being met. Seidman (2013) stated, "this sampling technique should allow the widest possibility for readers of the study to connect to what they are reading" (p. 56). The ten participants that I initially contacted represented sufficient variation sampling in which the larger population in the Islamic community was adequately represented.

Specifically, I aimed for ten women and men whose ethnic origins were as evenly divided as possible between Africa, the Middle East, Asia, and North America, which were the most common places of origin for Islamic school stakeholders in the United States. I selected five potential participants from the two groups (parents and teachers). Based on their responses to the Preliminary Questionnaire (see Appendix A) my participants were as evenly distributed as possible into groups, depending on the number of years of experience within their roles, number of children who attend Islamic school, and their length of enrollment. 
Similarly, based on their responses to the Follow-Up Questionnaire (see Appendix B) my participants were as evenly distributed as possible into groups depending on their level of satisfaction with Islamic education, primary expectations of Islamic education, the degree to which expectations were being met, and the reasons why expectations were or were not being met. As Seidman (2013) explained, "the above characteristics are illustrative but not exhaustive of the range of variations present in the population whose experience this researcher might want to try to understand" (p. 56).

Ultimately, I selected the ten participants to interview by analyzing the completed preliminary and follow-up questionnaires. The variety of responses on the questionnaires broadly represented the general population of teachers and parents at an Islamic school. For example, the ten participants that I interviewed were comprised of five parents and five teachers who varied in terms of their ethnicity, gender, age, roles, amount of experience in their roles in Islamic education, number of children who attended Islamic schools, categories of expectations of Islamic schools, rate of satisfaction with Islamic education, and reasons for satisfaction or dissatisfaction with Islamic education. This even and varied distribution was in alignment with the objective that Seidman (2013) described: "The goal would remain to sample purposely the widest variation of sites and people within the limits of the study" (p. 56).

\section{Procedures}

The procedures that I used to conduct the study for sample recruitment included a

Preliminary Questionnaire (see Appendix A), a Questionnaire Follow-Up (see Appendix B), and In-Depth Interviews (see Appendix C). I provided informed consent to all 
participants in order to protect their identity as much as possible and to ensure that they fully understood their role in the research. While maintaining data throughout the study, I adhered to the strictest measures of confidentiality to safeguard my participants and research sites as much as possible. The protocols and steps taken during data collection included the following: sending preliminary questionnaires, along with informed consent letters, to ten stakeholders who were members of a designated Islamic school on the West Coast, retrieving completed questionnaires and selecting ten participants to interview, contacting those ten participants to interview, sending interview questions in advance to allow participants sufficient time to prepare for the interview, and conducting individual, 90-minute, recorded interviews with the ten participants. Then I transcribed all interviews, interpreted the interviews and incorporated the meaning of the interviews into the study. I made sure that the participants knew that they could withdraw from the study at any time.

\section{Instruments and Measures}

My rationale for selecting both surveys and interview designs pertained to the complimentary nature of the two research instruments. Vogt et al. (2012) explained how the use of surveys and interviews helped to increase the reliability and validity of the study: "The standardization of survey questions helps improve the reliability of answers, while the in-depth probing of interview questions enhances the validity of the answers" (p. 34). Vogt et al. (2012) defined reliability as "the consistency or stability of an observation, measurement, or text from one instance to the next" (p. 349) and validity as "truly studying what we intend to study, using methods that are appropriate for the 
problem, and drawing accurate conclusions" (p. 355). Since reliability and validity were integral to conducting sound research, the proper use of survey and interview designs, both of which enhance reliability and validity, were appropriate choices for my research.

Vogt et al. (2012) encouraged the use of survey designs when certain research criteria were met: when the optimal way of receiving the data was directly from participants, when data could be obtained by short answers to structured questions, when respondents were likely to provide reliable answers, when the researcher knew in advance how the answers were used, and when the researcher could anticipate an adequate response rate. My own study fit the criteria that Vogt et al. (2012) suggested for using a survey design: the most efficient way of receiving data was directly from my participants rather than accessing records to which I had no access. For the purposes of the survey, which acted as an initial questionnaire, I needed short answers to structured questions. I anticipated that my respondents would provide reliable answers because they understood that the survey was confidential. Vogt et al. (2012) stated, "people who are willing to participate in research seem eager to try to give honest answers or to make an effort to remember correctly" (p. 17). I knew in advance how the survey answers would be used because I recognized how each survey question was related to my research problem. Finally, I expected an adequate response rate due to my relationship with my respondents based on mutual trust and respect, from one Muslim teacher and parent to another.

Of the three modes of survey administration that Vogt et al. (2012) described (face-to- face, telephone, and self-administered), I used the self-administered survey 
administration. Vogt et al. stated, "self-administered surveys are a huge bargain, respondents do all the work, and cost is minimal, especially when using internet" (p. 21). Other reasons for using self-administered surveys included: my respondents could understand the meaning of the questions, I wanted to be sure that my respondents receive exactly the same questions, and I had limited time and money. However, I needed to use face-to-face survey administration for a small number of respondents whose first language was not English so I could explain the meaning of some of the more nuanced questions.

Although the use of surveys served the important purpose of a preliminary questionnaire, the subsequent interviews that I conducted acted as the dominant research design for my study. Vogt et al. (2012) described the interdependence of interviewing and surveys that reflected my own plan to select participants who provided valuable insight into the study: "Interviewers usually select interviewees through purposive or judgment sampling, targeting individuals with specific knowledge, experiences, or characteristics" (p. 33). The specific knowledge, experience, and characteristics that I captured in the surveys included engaged and discerning participants whose knowledge about Islamic education was diverse, experience with Islamic schools was varied, and characteristics were distinct.

Vogt et al. (2012) further explained the qualities that surveys and interviews brought to the research design: 
Three main traits are shared by surveys and interviews: both can be directed to gathering personal/internal information or external/less personal information; both are based on trusting respondents or informants to answer honestly; and both struggle with complicated problems of interpreting meanings. (p. 34)

\begin{abstract}
All three traits related to my own research: I used surveys to gather less personal information, while the in-depth interviews that followed elicited more personal information. Since I established rapport with my participants, I trusted them to answer honestly. I built rapport with respondents by connecting with them on a personal level as a fellow Muslim, teacher, and parent. Finally, the use of surveys and interviews were my attempt to understand the meaning that my participants made of their deep-rooted experience with Islamic education.
\end{abstract}

The main reason for using the interview research design was that my participants had the information that I needed in order to answer my research questions. A way to get this information was to ask for it directly. Vogt et al. (2012) explained, "one reason to interview people is that they know things researchers want to know" (p. 39). Vogt et al. (2012) pointed out several other reasons to use interviews:

Interviews tend to be effective when you are seeking knowledge that is best obtained from members of your target population because it is subjective or internal to the people interviewed; when you seek in-depth answers from research participants; when generalizing to a large population is less important than learning in detail about a smaller group; and when the questions you ask require 
STAKEHOLDER EXPECATIONS OF ISLAMIC EDUCATION

that informants have time to reflect and seek clarification before answering, often because your questions probe difficult or sensitive matters of meaning and belief. (p. 36)

Those reasons coincided with my own decision to use interviews: The knowledge that I was seeking from my participants regarding their expectation of Islamic education was subjective, I was seeking in-depth answers from my respondents concerning their Islamic school experience, my focus was on a smaller group (10 interviewees from the Islamic community), and the nature of my exploratory questions required my participants to contemplate before answering questions that pertained to the meaning that they had made of their Islamic education experience.

Vogt et al. (2012) described a range of interview types, approaches, and procedures to consider when implementing the research interview design, such as exploratory, descriptive, explanatory, confirmatory, structured, different modes, formal or informal sites, and partnering with the informant (p. 47). For my study, I asked exploratory and descriptive interview questions in order to understand the phenomenon of the Islamic school experience that stakeholders were living through. Vogt et al. (2012) encouraged the use of exploratory and descriptive questions "when you want to learn as much as possible about a phenomenon or person, when context is important (p. 47). An exploratory and descriptive approach to interviewing, such as, "Describe your experience with Islamic education" allowed respondents to tell their own story, in their own way. Vogt et al. (2012) stated, "this kind of research is considered especially important because 
of the belief that most people, perhaps all, organize their understanding of themselves in the form of stories or narratives" (p. 38).

\section{Role of Researcher}

It was conceivable that my previous knowledge and experience with Islamic education could have led to biases in my research. I had spent the past sixteen years of my professional life teaching full time at two Islamic schools - a pre-k through kindergarten school for one year and a pre-k through twelfth grade school for the past fifteen years. Furthermore, my three high school and college age children attended Islamic schools since pre-school. In fact, I was their kindergarten, elementary, middle, and high school teacher for homeroom, social studies, and speech and debate for the past twelve years.

My interest in Islamic education emerged when my children were approaching school age. My husband, who was originally from India, our children, and I lived in the small, rural town where I grew up. Although our quiet community was an ideal setting, we believed, for raising young children, we felt that there were other aspects of our town that might work against our family in the post 9/11 era. We felt that raising our Muslim children from a mixed-race ethnic background in our tight-knit, predominately white Christian town might do them more harm than good.

We moved to a larger, more diverse city with a nearby mosque and an assortment of public and private schools. Soon afterward, when an announcement was made after Friday services at our mosque that a teaching position was available at the local Islamic school, I applied and was hired. I enrolled my three children in the school's kindergarten, 
pre-school, and toddler classes, and so began my career as a teacher in an Islamic school for the next sixteen years. Needless to say, my perspective on Islamic education was heavily influenced by the past several years of experience with parents, teachers, students, administrators, and community members who were committed to Islamic education. That said, there was always room for improvement in the Islamic school arena. Although I brought my biases into the study, as all quantitative researchers do to one degree or another, my aim was to move beyond these biases and understand what other stakeholders wanted out of their Islamic school experience in order to help bridge some of the gaps between the expectations and reality of the Islamic school experience. To that end, my personal and professional experience with Islamic education provided insight, rather than partiality, to the study.

\section{Data Collection and Analysis}

Throughout the data collection and analysis stages of my research, I used several procedures to help suspend bias. First, I finished recording all of my interviews before analyzing the transcripts. Seidman (2013) stated, "in that way I try to minimize imposing on the generative process of the interviews what I think I have learned from other participants" (p.116). Although it is impossible to prevent all researcher bias, this step minimized the bias that could have jeopardized my findings.

Next, I carefully transcribed the recorded interviews, including verbal and nonverbal material, in order to maintain the intent of the participant's meaning. Seidman (2013) warned, “to substitute the researcher's paraphrasing or summaries of what the participants say for their actual words is to substitute the researcher's consciousness for 
STAKEHOLDER EXPECATIONS OF ISLAMIC EDUCATION

that of the participant" (p. 117). Furthermore, Seidman (2013) recommended transcribing the entire interview as opposed to only a portion: "Preselecting parts of the recording to transcribe and omitting others tends to lead to premature judgments about what is important and what is not" (p. 118). Therefore, I transcribed all of the interviews and took careful notes about body language and other nonverbal cues.

Providing participants access to their recorded and transcribed interviews was another way to reduce bias. Seidman (2013) discussed how recording benefited the respondent: "The assurance that there is a record of what they have said to which they have access can give them more confidence that their words will be treated responsibly" (p. 117). The acts of recording, transcribing, and allowing participants access to the recording and transcription helped to minimize bias while maximizing transparency.

Another way that I suspended bias was by scrutinizing my own interest in the subject of Islamic education in order to expose any personal issues that might have distorted the study. Seidman (2013) stated, "it is important that the researcher identify his or her interest in the subject and examine it to make sure that the interest is not infused with anger, bias, or prejudice. The interviewer must come to the transcript prepared to let the interview breathe and speak for itself' (p. 121). Therefore, I shared my own opinions and expectations as I analyzed the data from the participants.

Finally, member-checking was an effective way to help suspend bias. Lightfoot (1983) stated, "the interviewer-researchers can later check with the participants to see if what they have marked as being of interest and import seems that way to the participants" 
(Seidman, 2013, p.120). I member checked by corresponding with each of my

respondents and provided them with a list of excerpts from the interview that I deemed significant. At that point, I gave them an opportunity to decide for themselves whether the passages that I selected seem as important to my respondents as they did to me.

I followed these steps during my data analysis: I determined what excerpts from the transcripts were important, I categorized these critical passages to facilitate the emergence of themes, and I sorted the key quotes into files that I could readily access. Although these steps seemed straightforward, Seidman (2013) described what could happen if the researcher had preconceived notions about the data: "The danger is that the researchers will try to force the excerpts into categories, and the categories into themes that he or she already has in mind, rather than let them develop from the experience of the participants as represented in the interviews" (p. 130). As I analyzed the data, I also kept analytical memos describing how I was feeling and reacting to the data. I then used these memos as checks as I drew conclusions from the data.

Krathwohl (2009) described coding in qualitative research as "the process of selecting what is important from the rest and naming it" (p. 314). Saldaña (2009) further explained how coding was "a method that enables you to organize and group similarly coded data into categories or "families" because they share some characteristic - the beginning of a pattern" (p. 8). The challenge in my own study was to determine what data was noteworthy and what was less significant. Then my task was to label the critical data in a meaningful way that facilitated the emergence of general themes. Krathwohl stated, "by setting forth generalizations that grew out of the data and stand above its detail — the 
ultimate stripping away of the unnecessary-we contribute to social science knowledge" (p. 314). My ultimate research goal was to contribute to the social science knowledge of Islamic education by helping to bridge the gaps between stakeholder expectations and the reality of Islamic schools.

Krathwohl (2009) identified four general techniques to identify codes that I used in my own data analysis: "Analysis of words, scrutiny of large text blocks, analysis of linguistic features, and physical manipulation of text” (p. 314). Saldaña (2009) cautioned, "be wary of relying on your memory for future writing. Get your thoughts, however fleeting, documented in some way" (p. 17). I divided the pages of my data into three columns: The first column included my interview transcripts, the second column was reserved for my preliminary coding notes, and the third column contained my final codes, as illustrated in the following table:

Table 3

Coding Columns

\begin{tabular}{|l|l|l|}
\hline Interview Transcripts & $\begin{array}{l}\text { Preliminary Coding } \\
\text { Notes }\end{array}$ & Final Codes \\
\hline & & \\
\hline
\end{tabular}

Saldaña (2009) advised emerging researchers of small-scale studies such as mine to code on hard-copy first: "There is something to be said for a large area of desk or table space with multiple pages or strips of paper spread out to see the smaller pieces of the larger puzzle - a literal perspective that is not always possible on a computer's monitor 
screen" (p. 22). I coded on hard-copy in order to develop a sense of ownership of my data.

Krathwohl (2009) then described a scheme provided by Bogdan and Biklen (2007) that I included in my study as a starting point for developing codes: 1.

Setting/context codes (descriptions of the setting, such as the Islamic school classroom or Muslim parent's home, which allow for larger context). 2. Definition- of-the-situation codes (how individual respondents, such as teachers and parents, understand the setting), for example, how a Muslim parent understands the use of time and space in the Islamic school. 3. Perspectives held by subjects (the shared way that respondents think about the setting), such as what Islamic school teachers collectively think about their Islamic school). 4. Subjects' ways of thinking about people and objects (respondents understanding of each other, outsiders, and objects), such as Muslim parents’ understanding of each other, their understanding of non- Muslim parents, and their understanding of their children's curriculum. 5. Process codes (sequences, transitions, and changes), such as graduating from an Islamic middle school. 6. Activity codes (behavior that occurs regularly), such as parents volunteering in the Islamic school classroom. 7. Event codes (infrequent events), such as suspension of Islamic school students. 8. Strategy codes (tactics, methods, and techniques), such as Islamic school student-led discussions. 9. Relationship and social structure codes (cliques, friendships, and enemies), such as examples of bullying in Islamic schools. 10. Narrative codes (the structure of talk), such as Islamic expressions used by teachers. Using this scheme helped me to determine what clues to look for in the data that answered my research questions. 
Since the participants in my study were part of the West Coast Muslim

community, which included a variety of cultures with their own languages, traditions, and values, it was appropriate to use In Vivo Coding in particular to "prioritize and honor the participant's voice" (Saldaña, 2009, p. 74). In Vivo literally means "in that which is alive," and as a code refers to a word or short phrase from the actual language found in the qualitative data record, "the terms used by [participants] themselves" (Strauss, 1987, p. 33). Charmaz (2006) further explained how "In Vivo Codes can provide a crucial check on whether you have grasped what is significant to the participant, and may help crystalize and condense meanings" (p. 57). Incorporating In Vivo Coding helped me to stay focused on the language that my participants used to express their Islamic school experiences.

Krathwohl (2009) listed fourteen steps for the analysis process that I incorporated into my study: 1. "Finding what is significant" (p. 316), meaning taking note of material that makes an impression, such as a parent's emphasis on their child memorizing Qur'an). 2. "Loading your mind" (p. 317), meaning becoming intimately acquainted with the material in order to see emerging patterns, such as teachers who repeatedly express the expectation of parent involvement at school. 3. "Letting one's unconscious process the data" (p. 317), meaning allowing the unconscious mind to sort and organize ideas. 4. "Beginning with initial codes" (p. 317), meaning coding material that naturally falls into categories, such as academic, cultural, and religious expectations. 5. "Checking the consistency of title with coded material" (p. 318), meaning ensuring that codes and titles match, such as a "modesty" code matching a "cultural" title. 6. "Adjusting code titles for 
better fit" (p. 319), meaning changing code titles when necessary, such as changing a "modesty" code from a "cultural" title to a "religious" title. 7. "Recoding at an interpretive level” (p. 319), meaning recoding as material becomes more complex, such as recoding as I discover deeper meaning in the material. 8. "Developing and testing working hypotheses" (p. 319), meaning cultivating and examining explanations for repeating patterns, such as the repeating pattern of "teaching Muslim character education" may be explained by parents' fear of child losing Islamic identity. 9. "Developing and testing generalizations" (p. 320), meaning determining whether or not generalizations are supported by the data and revise accordingly, such as verifying the generalization about the importance of teaching Arabic for cultural or religious reasons. 10. "Developing and testing descriptive types" (p. 320), meaning describing the characteristics that illustrate the group, such as teachers' educational, cultural, and religious backgrounds. 11. "Developing graphics to examine code relationships" (p. 321), meaning creating visual representation of relationships between code categories, such as creating a diagram illustrating parents' and teachers' academic, cultural, and religious expectations of Islamic schools. 12. "Developing explicit definitions of each code" (p. 321), meaning seeing relationships among codes, such as making distinctions between religious and cultural codes. 13. "Relating your findings to those of other researchers" (p. 323), meaning searching the literature to gain support, find rival explanations, or expose weak spots. 14. "Developing the report" (p. 323), meaning describing generalities acquired from the data, such as explaining the generality of Muslim parents' academic 
expectations. Following these scheme steps to analyze my data helped me to better understand and interpret the meaning of my interviews.

Thoroughly reading and rereading my interview transcript resulted in a deeper comprehension of the data. Crabtree and Miller (1999b) explained how repeatedly reading the data in different ways increased understanding while, at the same time, decreased bias. My first reading was done without presumptions with an eye toward the unexpected. During the second reading, I looked for themes that emerged during the first reading as well as any supporting or opposing evidence. In the third reading I returned to the data to determine if I overlooked anything of significance. The fourth reading was my opportunity to understand the data from multiple points of view. Finally, the fifth reading allowed me to make connections between incongruities that emerged from the fourth reading. Although combing through the details of the data took considerable time, these readings "facilitate a thorough understanding of what is in the data as well as reducing the likelihood of bias by forcing the researcher to explore the data from different angles" (Krathwohl, 2009, p. 328). Though time consuming, the numerous readings helped me to better understand my data as well as minimize bias, which was time well spent.

Seidman (2013) raised several important questions that researchers should ask themselves, including:

What have they learned from doing the interviews, studying transcripts, marking and labeling them, crafting profiles, and organizing categories of excerpts? What connective threads are there among the experiences of the participants they 
STAKEHOLDER EXPECATIONS OF ISLAMIC EDUCATION

interviewed? How do they understand and explain these connections? What do they understand now that they did not understand before they began the interviews? What surprises have there been?

What confirmations of previous instincts? How have their interviews been consistent with the literature? How inconsistent? How have they gone beyond? (pp. 130-131)

\section{Conclusion}

To study the social, academic, and cultural expectations of teachers and parents affiliated with Islamic schools, I used a qualitative (Maxwell, 2013; Creswell, 2013), phenomenological (Seidman, 2013) approach. First, I asked teachers and parents from an Islamic school on the West Coast to complete a preliminary questionnaire in order to obtain a purposeful selection of participants (Maxwell, 2013). After checking the responses on the questionnaire, I sent a follow- up questionnaire to the ten respondents which probed more deeply into the social, academic, and cultural expectations of stakeholders. Next, I contacted the ten potential participants directly to ask them to take part in in-depth interviews. Finally, I conducted in-depth interviews of five teachers and five parents for around ninety minutes each using an audio recorder. Throughout the interview process, I was guided by Seidman's (2013) phenomenological themes in which the researcher strives to understand the essence of the lived experience of participants.

Later, I transcribed each interview before analyzing the data in order to minimize bias (Seidman, 2013). I analyzed the data by coding the interviews using Krathwohl 
(2009) steps in coding and analysis. By incorporating a preliminary questionnaire, a follow-up questionnaire, in- depth interviews, and coding and analysis of the data, I was able to make sense of the social, academic, and cultural expectations of teachers and parents in a particular Islamic school on the West Coast. I hope my study will help other researchers understand the expectations of stakeholders in other Islamic schools.

Furthermore, my goal is to prepare the way for Islamic schools to better fulfill these expectations. In the next chapter, I explain my analysis of the data and what I realized about the expectations of teachers and parents in Islamic schools. 


\section{Chapter 4: Results and Analysis}

The purpose of my study was to explore the expectations of teachers and parents in an Islamic School on the West Coast in order understand how these expectations could be fulfilled in other Islamic schools across the United States. I asserted that teachers and parents made considerable sacrifices to affiliate themselves with Islamic schools. As they committed to Islamic education, they acquired certain expectations that they wanted their school to fulfill. In order to understand these expectations, I proposed a study with two research questions in mind:

1. What are the academic, social, and cultural expectations that parents and teachers have of their Islamic schools?

2. To what extent are Islamic schools meeting the expectations of parents and teachers?

To answer these research questions, I integrated a qualitative (Maxwell, 2013),

phenomenological approach (Creswell, 2013) in which I surveyed parents and teachers in a West Coast Islamic school using preliminary and follow-up questionnaires. Then I conducted 90- minute, in-depth interviews with teachers and parents. I purposefully selected my participants to include the teachers and parents who were most likely to provide answers to my research questions (Maxwell, 2013). The participants were from an Islamic school on the West Coast (WCIS) whose backgrounds varied in order to incorporate a diversity of voices in the study.

I gathered data from preliminary questionnaires, follow-up questionnaire 
and in-depth interviews to answer my research questions. These were my data sources. In this chapter I will detail how I analyzed these data.

\section{Analysis of Data}

To analyze the data, I incorporated a series of coding procedures explained by Saldaña (2009), and I implemented elements of an analysis process identified by Krathwohl (2009). I used three data instruments — a Preliminary Questionnaire, a Questionnaire Follow- Up, and In- Depth Interview Questions — to triangulate the study. I transferred the data I collected from the Preliminary Questionnaires onto summary tables to highlight the purposeful selection of teachers and parents for the study. After collecting the data from the Questionnaires Follow-Ups, I transferred the data to summary tables to show the levels of participant satisfaction for academic, social and cultural expectations. In the following section, I describe the steps I took to analyze each of the data sources.

Table 4

Coding Methods

\begin{tabular}{|l|l|l|l|l|l|}
\hline Questionnaires & $\begin{array}{l}\text { Interview } \\
\text { Transcripts }\end{array}$ & $\begin{array}{l}\text { Preliminary } \\
\text { Coding }\end{array}$ & $\begin{array}{l}\text { Secondary } \\
\text { Coding }\end{array}$ & Final coding & Theme \\
\hline $\begin{array}{l}\text { Magnitude } \\
\text { coding }\end{array}$ & $\begin{array}{l}5 \text { teachers } \\
5 \text { parents }\end{array}$ & $\begin{array}{l}\text { In Vivo } \\
\text { Coding }\end{array}$ & $\begin{array}{l}\text { Pattern } \\
\text { Coding }\end{array}$ & "Trinity" & $\begin{array}{l}\text { Encapsulating } \\
\text { theme }\end{array}$ \\
\hline
\end{tabular}

\section{Preliminary Questionnaires}

The purpose of the Preliminary Questionnaires was to help me make decisions about the upcoming in-depth interviews, such as whom to interview and what interview questions to ask. I wanted to include a variety of participants with various backgrounds in 
order to enrich my study with a diversity of voices. I felt that participants with diverse backgrounds would answer my research questions in a way that would best reflect the attitudes of the school community members that they represented. Furthermore, I wanted to make decisions about what supporting interview questions to ask that would help participants to thoroughly answer the main research questions. The responses on the questionnaires enabled me to select participants who were likely to provide insightful answers to my interview questions.

\section{Coding the Data}

I used Magnitude Coding (Saldana, 2009) to code the data on the Preliminary Questionnaires. Saldana (2009) explained how Magnitude Coding “consists of and adds a supplemental alphanumeric or symbolic code or sub-code to an existing coded datum or category to indicate its intensity, frequency, direction, presence, or evaluation content" (p. 58). Magnitude Coding allowed me to present the content of the Preliminary Questionnaires in summary tables for "at a glance analysis" (p. 60).

After transcribing the interviews, I read and reread the interview transcripts several times to deepen my understanding of the data (Crabtree \& Miller, 1999b). The first cycle coding method I applied was In Vivo Coding (Saldaña, 2009), in which I extracted key phrases that all ten participants actually stated from each interview transcript and listed these phrases in a preliminary coding chart. I used Pattern Coding (Saldaña, 2009) for the second cycle coding method which further identified developing themes by sorting In Vivo Codes into a smaller number of meaningful categories. The final coding consisted of determining the study's "trinity” (Saldaña, 2009) by finalizing 
the three dominant themes that emerged from the pattern codes. By highlighting the "trinity" that emerged from the pattern codes, I identified how the three themes were interrelated. I then encapsulated the interconnecting components within the "trinity" into a final theme for each of the expectation categories (academic, social, and cultural).

\section{Presentation of Results}

\section{Preliminary Questionnaire-Teachers}

The five Preliminary Questionnaires that were returned to me from teachers (see Table 2) revealed that they were all female. Their countries of origin included Iran, Kuwait, Libya, the United States, and Jordan. None of the teachers attended Islamic schools when they were students. Two of the teachers identified as parents as well as teachers as their main roles in their current Islamic school. All of the teachers had been teaching at their Islamic school for six or more years. One of the teachers had taught in a non- Islamic school for fifteen years. Four of the teachers had at least three children who attended their Islamic school. Those four teachers' children had attended Islamic school for three years or more.

Table 5

\section{Preliminary Questionnaire-Teachers}

\begin{tabular}{|c|c|c|c|c|c|}
\hline Questions & Teacher \#1 & Teacher \#2 & Teacher \#3 & Teacher \#4 & Teacher \#5 \\
\hline $\begin{array}{l}\text { What is your } \\
\text { gender? }\end{array}$ & $\mathrm{F}$ & F & $\mathrm{F}$ & F & F \\
\hline Country of origin? & IR & $\mathrm{KW}$ & LY & US & JO \\
\hline $\begin{array}{l}\text { Attended Islamic } \\
\text { school? }\end{array}$ & $\mathrm{N}$ & $\mathrm{N}$ & $\mathrm{N}$ & $\mathrm{N}$ & $\mathrm{N}$ \\
\hline $\begin{array}{l}\text { Where attended } \\
\text { Islamic school? }\end{array}$ & N/A & N/A & $\mathrm{N} / \mathrm{A}$ & $\mathrm{N} / \mathrm{A}$ & $\mathrm{N} / \mathrm{A}$ \\
\hline $\begin{array}{l}\text { How many years } \\
\text { attended Islamic } \\
\text { school? }\end{array}$ & N/A & N/A & $\mathrm{N} / \mathrm{A}$ & $\mathrm{N} / \mathrm{A}$ & $\mathrm{N} / \mathrm{A}$ \\
\hline
\end{tabular}




\begin{tabular}{|l|l|l|l|l|l|}
\hline $\begin{array}{l}\text { Main role in } \\
\text { current Islamic } \\
\text { shool? }\end{array}$ & T & T & T \& & T \& P & T \\
\hline $\begin{array}{l}\text { How long in this } \\
\text { role? }\end{array}$ & $6+$ & $6+$ & $6+$ & $6+$ & $6+$ \\
\hline $\begin{array}{l}\text { Ever taught in } \\
\text { non-Islamic } \\
\text { school? }\end{array}$ & N & N & Y & N & N \\
\hline $\begin{array}{l}\text { How many years? } \\
\text { Now many } \\
\text { children attended } \\
\text { Islamic school? }\end{array}$ & $5+$ & N/A & 15 & N/A & N/A \\
\hline $\begin{array}{l}\text { How many years } \\
\text { enrolled in Islamic } \\
\text { school? }\end{array}$ & $7+$ & N/A & $7+$ & $3-4$ & $3-4$ \\
\hline
\end{tabular}

\section{Analysis of Preliminary Questionnaire-Teachers}

For the most part, the five Preliminary Questionnaires returned by teachers met my criteria for diversity. I knew that all of the teacher respondents would be female since only females taught at WCIS. The teacher respondents originated from a variety of countries, although most came from the Middle East. All of the teachers had taught in their Islamic school for several years, and one of the teachers had taught in a non-Islamic school for an extended period. Most of the teachers had children who attended Islamic school for several years, while one of the teachers had no children. Although I preferred to select participants who represented a wider variety of backgrounds, such as males as well as females, participants from several continents, and new teachers as well as experienced teachers for example, I believed that the teacher respondents sufficiently met my criteria for diversity to allow for a rich sampling of voices. 
STAKEHOLDER EXPECATIONS OF ISLAMIC EDUCATION

\section{Results of Preliminary Questionnaire-Parents}

In the Preliminary Questionnaire for parents (see Table 3), the data showed that four of the five parent respondents were female and one was male. Their countries of origin included the United States, Libya, Syria, the Philippines, and Somalia. One of the parents attended Islamic school for five years when she was a student in Syria. One of the parents identified as a teacher as well as parent as their main roles in their current Islamic school. Four out of the five parents had been in the role of parent at the Islamic school for six or more years. The other parent had been in the role of parent at the Islamic school between one and three years. The parents' occupations included medical staff service specialist, physician, registered nurse, teacher, and stay-at-home mother. None of the parents had taught in an Islamic school. Two of the parents had one or two children who attended Islamic school. Two other parents had three or four children who attended Islamic school. One parent had more than five children who attended Islamic school. Two of the parents had children who attended Islamic school for at least three years. One parent had children who attended Islamic school for at least five years. Two other parents had children who attended Islamic school for at least seven years.

Table 6

\section{Preliminary Questionnaire-Parents}

\begin{tabular}{|l|l|l|l|l|l|}
\hline Questions & Parent \#1 & Parent \#2 & Parent \#3 & Parent \#4 & Parent \#5 \\
\hline $\begin{array}{l}\text { What is your } \\
\text { gender? }\end{array}$ & F & M & F & F & F \\
\hline Country of origin? & US & LY & SY & PH & SO \\
\hline $\begin{array}{l}\text { Attended Islamic } \\
\text { school? }\end{array}$ & N & N & Y & N & N \\
\hline
\end{tabular}




\begin{tabular}{|l|l|l|l|l|l|}
\hline $\begin{array}{l}\text { Where attended } \\
\text { Islamic school? }\end{array}$ & N/A & N/A & SY & N/A & N/A \\
\hline $\begin{array}{l}\text { How many years } \\
\text { attended Islamic } \\
\text { school? }\end{array}$ & N/A & N/A & S & N/A & N/A \\
\hline $\begin{array}{l}\text { Main role in } \\
\text { current Islamic } \\
\text { school? }\end{array}$ & $\mathrm{P}$ & $\mathrm{P}$ & $\mathrm{P}$ & $\mathrm{T} \& \mathrm{P}$ & $\mathrm{P}$ \\
\hline $\begin{array}{l}\text { How many years } \\
\text { in this role? }\end{array}$ & $6+$ & $6+$ & $1-3$ & $6+$ & $6+$ \\
\hline $\begin{array}{l}\text { Occupation? } \\
\text { Medical staff } \\
\text { services } \\
\text { specialist }\end{array}$ & Dr. & RN & T & $\begin{array}{l}\text { Stay-at-home- } \\
\text { mom }\end{array}$ \\
\hline $\begin{array}{l}\text { Have you taught } \\
\text { in non-Islamic } \\
\text { school? }\end{array}$ & $\mathrm{N}$ & $\mathrm{N}$ & $\mathrm{N}$ & $\mathrm{N}$ & No \\
\hline $\begin{array}{l}\text { How many } \\
\text { children attended } \\
\text { Islamic school? }\end{array}$ & $1-2$ & $3-4$ & $3-4$ & $1-2$ & $5+$ \\
\hline $\begin{array}{l}\text { How many years } \\
\text { enrolled in Islamic } \\
\text { school? }\end{array}$ & $5-6$ & $7+$ & $3-4$ & $3-4$ & $7+$ \\
\hline
\end{tabular}

\section{Analysis of Preliminary Questionnaire-Parents}

Similar to the Preliminary Questionnaires returned by teachers, the Preliminary

Questionnaires returned by parents generally met my criteria for diversity because of the variety of backgrounds that the parents represented. Again, I would have preferred to hear from more male parents, but ultimately I was pleased to receive at least one Preliminary Questionnaire from a male parent, as it was difficult to communicate with males as a female researching in a gender-conservative environment. The parent respondents originated from a variety of regions in the Middle East, Asia, Africa, and the United States. Again, I would have preferred to hear from more parents who had previous experience as a student in an Islamic school, but I was glad that at least one respondent had attended an Islamic school as a student. Most of parent respondents were long term parents at WCIS which was an advantage in one way and a disadvantage in another: on 
one hand, the parent respondents could draw from many years of experience as a parent at WCIS. On the other hand, I was unable to learn about the experiences of short term Islamic school parents. All of the parent respondents worked in an assortment of occupations. Additionally, they had a wide ranging number of children who attended WCIS spanning several years. Similar to the responses in the Preliminary Questionnaire for teachers, I was generally satisfied with the degree of over-all diversity from the parent respondents.

\section{Questionnaire Follow-up Themes-Teachers and Parents}

The purpose of the Follow-Up Questionnaires was to provide an opportunity for participants to prepare themselves for the subsequent in-depth interviews. The questions on the Follow-Up Questionnaire reflected the overarching ideas behind the more specific In-Depth Interview Questions that followed. Participants were given time to read the questions carefully and write down responses at their leisure. Completing the Follow-Up Questionnaires acted as a warm-up for participants before delving into the In-Depth Interview Questions. Furthermore, the responses on the Follow-Up Questionnaires allowed me to get a sense of the general attitude that participants had regarding their Islamic education experience.

I identified general trends that emerged from each of the questions on the Questionnaire Follow-Up for teachers and parents. For the first question, How satisfied are you with the quality of education at your Islamic school? teachers' responses ranged from somewhat satisfied to extremely satisfied, while parents' responses ranged from 
satisfied to extremely satisfied. The second question, What are your primary expectations of your Islamic school? most teachers listed all three categories (academic, social, and cultural/religious) while parents answered similarly with the added emphasis to religious expectations. For the third question, Are your expectations being met by Islamic school? teachers tended to agree, with the condition that there was room for improvement. Parents answered similarly to the same question, that there was room for improvement. For the final question, How are your expectations are being met? most of the teachers opted to answer this question in more detail during the in-depth interview. However, the two teachers who chose to respond on the Questionnaire Follow-Up mentioned the rigorous curriculum, emphasis on community building, and exemplary Islamic influence in the classroom as examples of how their expectations were being met. The parent who responded to the same question stated that her expectations were being met by the care, engagement, and creativity that teachers demonstrated in the classroom.

Generally, both teachers and parents responded favorably to questions on the Questionnaire Follow-Up: they were satisfied with the quality of education at their Islamic school, they expected a holistic curriculum with an emphasis on religious education, their expectations were largely being met, although they added that there was room for improvement, and finally, both teachers and parents mentioned that their expectations were being met by the Islamic influence in the classroom as demonstrated by their exemplary teachers.

Table 7 
Questionnaire Follow-Up-Teachers

\begin{tabular}{|c|c|c|c|c|c|}
\hline Questions & Teacher \#1 & Teacher \#2 & Teacher \#3 & Teacher \#4 & Teacher \#5 \\
\hline \begin{tabular}{|l|} 
How satisfied \\
are you with \\
quality of \\
education at \\
Islamic school?
\end{tabular} & $\begin{array}{l}\text { Somewhat } \\
\text { satisfied }\end{array}$ & Satisfied & $\begin{array}{l}\text { Extremely } \\
\text { satisfied }\end{array}$ & $\begin{array}{l}\text { Extremely } \\
\text { satisfied }\end{array}$ & Satisfied \\
\hline $\begin{array}{l}\text { What are your } \\
\text { primary } \\
\text { expectations of }\end{array}$ & $\begin{array}{l}\text { Academic, } \\
\text { religious and } \\
\text { social }\end{array}$ & Religious & \begin{tabular}{|l|} 
Academic, \\
religious, and \\
social
\end{tabular} & $\begin{array}{l}\text { Academic, } \\
\text { religious, and } \\
\text { social }\end{array}$ & $\begin{array}{l}\text { Academic, } \\
\text { cultural and } \\
\text { religious }\end{array}$ \\
\hline \multicolumn{6}{|l|}{ Islamic school? } \\
\hline \begin{tabular}{|l|} 
Are your \\
expectations \\
being met by \\
Islamic school?
\end{tabular} & $\begin{array}{l}\text { Yes, but room for } \\
\text { Improvement }\end{array}$ & $\begin{array}{l}\text { Yes, but room for } \\
\text { improvement }\end{array}$ & Definitely, yes & $\begin{array}{l}\text { Yes, but room for } \\
\text { improvement }\end{array}$ & $\begin{array}{l}\text { Definitely, } \\
\text { yes }\end{array}$ \\
\hline $\begin{array}{l}\text { How are your } \\
\text { expectations } \\
\text { are being met? }\end{array}$ & $\begin{array}{l}\text { Described in } \\
\text { Interview }\end{array}$ & $\begin{array}{l}\text { Described in } \\
\text { interview }\end{array}$ & $\begin{array}{l}\text { High level of } \\
\text { academic } \\
\text { curriculum and } \\
\text { very strong } \\
\text { Islamic } \\
\text { curriculum. We } \\
\text { also focus on } \\
\text { community } \\
\text { building and } \\
\text { social skills. }\end{array}$ & $\begin{array}{l}\text { I appreciate that } \\
\text { the teachers are } \\
\text { Muslim and are } \\
\text { imparting Islamic } \\
\text { values on their } \\
\text { students. }\end{array}$ & $\begin{array}{l}\text { Described in } \\
\text { interview }\end{array}$ \\
\hline
\end{tabular}

Table 8

Questionnaire Follow-Up-Parents

\begin{tabular}{|l|l|l|l|l|l|}
\hline Questions & Parent \#1 & Parent \#2 & Parent \#3 & Parent \#4 & Parent \#5 \\
\hline $\begin{array}{l}\text { How satisfied are } \\
\text { you with quality } \\
\text { of education at } \\
\text { Islamic school? }\end{array}$ & Satisfied & Satisfied & Satisfied & Satisfied & $\begin{array}{l}\text { Extremely } \\
\text { satisfied }\end{array}$ \\
\hline $\begin{array}{l}\text { What are your } \\
\text { primary } \\
\text { expectations of } \\
\text { Islamic school? }\end{array}$ & $\begin{array}{l}\text { Academic and } \\
\text { religious }\end{array}$ & $\begin{array}{l}\text { Religious- } \\
\text { Qur'an, morals, } \\
\text { Arabic }\end{array}$ & $\begin{array}{l}\text { Academic, } \\
\text { religious and } \\
\text { social }\end{array}$ & Religious & $\begin{array}{l}\text { Academic, } \\
\text { cultural, } \\
\text { religious, and } \\
\text { social }\end{array}$ \\
\hline
\end{tabular}




\begin{tabular}{|l|l|l|l|l|l|}
\hline $\begin{array}{l}\text { Are your } \\
\text { expectations } \\
\text { being met by } \\
\text { Islamic school? }\end{array}$ & $\begin{array}{l}\text { Yes, but room for } \\
\text { improvement }\end{array}$ & $\begin{array}{l}\text { Yes, but room for } \\
\text { improvement }\end{array}$ & $\begin{array}{l}\text { Yes, but room for } \\
\text { improvement }\end{array}$ & $\begin{array}{l}\text { Yes, but room } \\
\text { for } \\
\text { improvement }\end{array}$ & $\begin{array}{l}\text { Yes, but room } \\
\text { for improvement }\end{array}$ \\
\hline $\begin{array}{l}\text { How are your } \\
\text { expectations are } \\
\text { being met? }\end{array}$ & $\begin{array}{l}\text { Teaching staff } \\
\text { are exceptional } \\
\text { human beings } \\
\text { that care for the } \\
\text { students above } \\
\text { and beyond what } \\
\text { I've seen in } \\
\text { public school. } \\
\text { They are } \\
\text { engaging, } \\
\text { creative and } \\
\text { intelligent. }\end{array}$ & $\begin{array}{l}\text { Arabic and } \\
\text { Qur'an much } \\
\text { improved for my } \\
\text { daughters. }\end{array}$ & $\begin{array}{l}\text { Described in } \\
\text { interview }\end{array}$ & $\begin{array}{l}\text { Described in } \\
\text { interview }\end{array}$ & $\begin{array}{l}\text { Described in } \\
\text { interview }\end{array}$ \\
& & & & & \\
\hline
\end{tabular}

\section{Presentation of Results}

To present the results, I explore the themes, discuss how the themes originate from participants, and illustrate how the themes answer the research questions. The following is an explanation of the themes that emerged from the teacher and parent Questionnaire Follow-Ups (see Tables 4 and 5) and In-Depth Interviews (see Tables 6 and 7) regarding participants' academic, social, and cultural expectations of Islamic education. I combined the data sources (Preliminary Questionnaire, Questionnaire Follow-Up, and In-depth Interviews) to examine the extent to which the Islamic school met the expectations of teachers and parents.

\section{Teacher Interview Themes}

In the interviews, I found eight themes that emerged from the teachers' responses: The themes related to academic expectations included the need to prepare Muslim students to succeed in the outside world, and families and teachers working together to 
support students who are struggling. The themes related to social expectations included the need for healthy relationships within school community, and balance and support within school community. The themes related to cultural expectations included the need for students to understand their own and each other's cultures, and respect for cultural heritage within the school community. The themes related to religious expectations, a subcategory of cultural expectations, included the need for the school community to apply Islamic values taught at school.

\section{Parent Interview Themes}

When I interviewed the parents, I found eight themes that surfaced from their responses: The themes related to academic expectations included the need for parents to have optimal education experiences for their children, and parents attributing children's academic success to a supportive environment at school. The themes related to social expectations included the need for children to develop their character at school. Parents were especially satisfied with children learning how to interact appropriately with opposite sex. However, parents felt that they had to supplement their children's social needs, such as team sports, outside of school with extracurricular activities. The themes related to cultural expectations included the need for children to learn about their own culture and different cultures, although they want the school to emphasize Islamic culture in particular. Parents felt that children's cultures were well- represented at school, but their Islamic culture should be emphasized over home country culture. The themes related to religious expectations, a subcategory of cultural expectations, included the need for children to have a strong Muslim identity. Parents believed that their Islamic school 
was teaching their children to be good people. Furthermore, parents stressed the importance of teaching a relevant curriculum and using contemporary teaching methods in the classroom.

\section{Organization and Presentation of Data and Analysis}

Next, I combined and analyzed the data to illustrate how themes emerged from teacher and parent responses on the Questionnaire Follow-Ups and In-Depth Interviews. I set the stage with the data in the In-Depth Interview questions regarding why teachers chose to work at an Islamic school and why parents chose to enroll their children in an Islamic school. Next, I presented the data in the In-Depth Interviews for the academic, social, and cultural expectations of teachers as well as the origin of teachers' academic, social, and cultural expectations. This led to my analysis of academic, social, and cultural expectations on the Questionnaire Follow- ups for teachers and parents. The data for the In-Depth Interviews of the academic, social, and cultural expectations of parents followed, along with the data for the In- Depth Interviews on the origin of parents' academic, social, and cultural expectations. Finally, I combined the themes that emerged after analyzing the data from the Questionnaire Follow-Ups and in-Depth Interviews on the academic, social, and cultural expectations of teachers and parents (see Tables $9 \&$ $10)$.

Table 9

In-Depth Interview Themes-Teachers 


\begin{tabular}{|c|c|c|}
\hline $\begin{array}{l}\text { As a teacher at an Islamic school, } \\
\text { what is your experience with } \\
\text { Islamic education? What made } \\
\text { you interested in teaching at an } \\
\text { Islamic school? }\end{array}$ & $\begin{array}{l}\text { Involvement in own children's } \\
\text { education } \\
\text { 2. Personal responsibility to teach } \\
\text { Muslim students } \\
\text { 3. Emphasis on teaching Arabic } \\
\text { language }\end{array}$ & Personal sense of duty \\
\hline $\begin{array}{l}\text { What academic expectations do } \\
\text { you have of your Islamic school? }\end{array}$ & $\begin{array}{l}\text { Foster Islamic identity in students } \\
\text { Prepare students for outside world } \\
\text { 3. Provide academically rigorous } \\
\text { education }\end{array}$ & $\begin{array}{l}\text { Prepare Muslim students to succeed } \\
\text { in outside world }\end{array}$ \\
\hline $\begin{array}{l}\text { Why do you have these academic } \\
\text { expectations? Describe how your } \\
\text { background, values, faith, culture, } \\
\text { and anything else you would like } \\
\text { to add, influence your } \\
\text { expectations. }\end{array}$ & $\begin{array}{l}\text { 1. Past teachers who set high } \\
\text { standards } \\
\text { Family pushed children to succeed } \\
\text { Importance of speaking Arabic } \\
\text { and reading Qur'an was stressed } \\
\text { while growing up }\end{array}$ & $\begin{array}{l}\text { Teachers' childhood experiences } \\
\text { with family and school }\end{array}$ \\
\hline $\begin{array}{l}\text { Are your academic expectations } \\
\text { being met? If yes, how? If not, } \\
\text { why not? }\end{array}$ & $\begin{array}{l}\text { 1. Families and teachers need to } \\
\text { work together to help students who } \\
\text { are struggling } \\
\text { 2. Students are struggling with } \\
\text { Arabic language } \\
\text { School is lacking basic resources }\end{array}$ & $\begin{array}{l}\text { School community working } \\
\text { together to support students who are } \\
\text { struggling }\end{array}$ \\
\hline $\begin{array}{l}\text { What social expectations do you } \\
\text { have of your Islamic school? }\end{array}$ & $\begin{array}{l}\text { 1. Healthy learning environment } \\
\text { 2. Clear communication } \\
\text { 3. Respectful relationships within } \\
\text { school community }\end{array}$ & $\begin{array}{l}\text { Healthy relationships within } \\
\text { school community }\end{array}$ \\
\hline $\begin{array}{l}\text { Why do you have these social } \\
\text { expectations? Describe how your } \\
\text { background, values, faith, culture, } \\
\text { and anything else you would like } \\
\text { to add, influence your } \\
\text { expectations. }\end{array}$ & $\begin{array}{l}\text { Influence of extended family } \\
\text { 2. Islamic emphasis on } \\
\text { cooperation and equality } \\
\text { 3. Classroom as a family }\end{array}$ & $\begin{array}{l}\text { Islamic emphasis on familial } \\
\text { relationships }\end{array}$ \\
\hline $\begin{array}{l}\text { Are your social expectations } \\
\text { being met? If yes, how? If not, } \\
\text { why not? }\end{array}$ & $\begin{array}{l}\text { Not enough parent involvement } \\
\text { 2. Family relationship between } \\
\text { teachers } \\
\text { 3. Students need to learn social } \\
\text { courtesies to have healthy } \\
\text { relationships }\end{array}$ & $\begin{array}{l}\text { Need balance and support within } \\
\text { school community }\end{array}$ \\
\hline
\end{tabular}




\begin{tabular}{|c|c|c|}
\hline $\begin{array}{l}\text { What cultural expectations do you } \\
\text { have of your Islamic school? }\end{array}$ & $\begin{array}{l}\text { Important to respect students' } \\
\text { cultural identity } \\
\text { Students caught between parents' } \\
\text { culture and American culture } \\
\text { Muslim identity is common } \\
\text { denominator in students' cultures }\end{array}$ & $\begin{array}{l}\text { Students should understand their } \\
\text { own and each other's cultural } \\
\text { identities }\end{array}$ \\
\hline $\begin{array}{l}\text { Why do you have these cultural } \\
\text { expectations? Describe how your } \\
\text { background, values, faith, culture, } \\
\text { and anything else you would like } \\
\text { to add, influence your } \\
\text { expectations. }\end{array}$ & $\begin{array}{l}\text { 1. Respecting culture prepares } \\
\text { students for outside world } \\
\text { 2. Family emphasized strong } \\
\text { Islamic character } \\
\text { 3. Following school rules helps } \\
\text { students follow rules of society }\end{array}$ & $\begin{array}{l}\text { Respecting culture prepares } \\
\text { students for future success }\end{array}$ \\
\hline $\begin{array}{l}\text { Are your cultural expectations } \\
\text { being met? If yes, how? If not, } \\
\text { why not? }\end{array}$ & $\begin{array}{l}\text { 1. Students are from many } \\
\text { cultures and accept each other } \\
\text { 2. Teachers have high morale and } \\
\text { enjoy working at school } \\
\text { 3. Students need Arabic language } \\
\text { support at school and home }\end{array}$ & $\begin{array}{l}\text { Respect for cultural heritage within } \\
\text { the school community }\end{array}$ \\
\hline $\begin{array}{l}\text { (subcategory of cultural } \\
\text { expectation) What religious } \\
\text { expectations do you have of your } \\
\text { Islamic school? }\end{array}$ & $\begin{array}{l}\text { 1. Students expected to } \\
\text { demonstrate their faith } \\
\text { 2. Parents are expected to support } \\
\text { Islamically acceptable behavior } \\
\text { that school is emphasizing } \\
\text { 3. Teachers are expected to model } \\
\text { Islamic behavior to students }\end{array}$ & $\begin{array}{l}\text { School community should apply the } \\
\text { Islamic values taught at school }\end{array}$ \\
\hline $\begin{array}{l}\text { Why do you have these religious } \\
\text { expectations? }\end{array}$ & $\begin{array}{l}\text { 1. Teachers are accountable to } \\
\text { Allah. 2.Influence of family } \\
\text { 3.Influence of cultural values }\end{array}$ & $\begin{array}{l}\text { Relationship with God, family and } \\
\text { cultural influences }\end{array}$ \\
\hline $\begin{array}{l}\text { Are your religious expectations } \\
\text { being met? If yes, how? If not, } \\
\text { why not? }\end{array}$ & $\begin{array}{l}\text { 1. Students have strong Muslim } \\
\text { identity } \\
\text { 2. Islam integrated into other } \\
\text { subjects } \\
\text { 3. Parents don't always reinforce } \\
\text { Islamic behavior that's taught in }\end{array}$ & $\begin{array}{l}\text { Parents should reinforce Islamic } \\
\text { behavior that's taught at school }\end{array}$ \\
\hline
\end{tabular}


STAKEHOLDER EXPECATIONS OF ISLAMIC EDUCATION

\begin{tabular}{|c|c|c|}
\hline & School & \\
\hline $\begin{array}{l}\text { Final thoughts on Islamic } \\
\text { education }\end{array}$ & 1.School lacks resources due to & $\begin{array}{l}\text { Islamic education makes a } \\
\text { positive difference in lives of } \\
\text { students, academically and }\end{array}$ \\
\hline & $\begin{array}{l}\text { limited budget } \\
\text { 2. Students from Islamic schools } \\
\text { confident in their Muslimidentity } \\
\text { 3. Students successful } \\
\text { academically and Islamically } \\
\text { 4. Islamic school is good long- } \\
\text { term spiritual investment for } \\
\text { students }\end{array}$ & $\begin{array}{l}\text { spiritually in spite of limited } \\
\text { resources }\end{array}$ \\
\hline
\end{tabular}

\section{Table 10}

\section{In-Depth Interview Themes-Parents}

\begin{tabular}{|c|c|c|}
\hline Questions & Final Codes & Themes \\
\hline $\begin{array}{l}\text { As a parent at an Islamic school, what is } \\
\text { your experience with Islamic education? } \\
\text { What made you interested in sending } \\
\text { your child to an Islamic school? }\end{array}$ & $\begin{array}{l}\text { 1. Priority for parents to } \\
\text { provide children with strong } \\
\text { Islamic foundation } \\
\text { 2. If children understand } \\
\text { Arabic, they'll understand } \\
\text { Islam and culture } \\
\text { 3. Islamic school acts as } \\
\text { extended family support for } \\
\text { child }\end{array}$ & $\begin{array}{l}\text { Parents deeply committed to } \\
\text { Islamic school experience for their } \\
\text { children }\end{array}$ \\
\hline
\end{tabular}




\begin{tabular}{|c|c|c|}
\hline $\begin{array}{l}\text { What academic expectations do you have } \\
\text { of your Islamic school? }\end{array}$ & $\begin{array}{l}\text { For students to excel in } \\
\text { their studies } \\
\text { 2. To balance lecture style } \\
\text { with creative learning } \\
\text { 3. To have small class size } \\
\text { that will allow for one-on- one } \\
\text { help for students }\end{array}$ & $\begin{array}{l}\text { Parents want to have optimal } \\
\text { education experience for their } \\
\text { children }\end{array}$ \\
\hline $\begin{array}{l}\text { Why do you have these academic } \\
\text { expectations? Describe how your } \\
\text { background, values, faith, culture, and } \\
\text { anything else you would like to add, } \\
\text { influence your expectations. }\end{array}$ & $\begin{array}{l}\text { 1. Parents came from } \\
\text { background where education } \\
\text { strongly encouraged }\end{array}$ & $\begin{array}{l}\text { Parents' cultural and family } \\
\text { background influenced their high } \\
\text { academic expectations. }\end{array}$ \\
\hline $\begin{array}{l}\text { Are your academic expectations being } \\
\text { met? If yes, how? If not, why not? }\end{array}$ & $\begin{array}{l}\text { There's a loving } \\
\text { environment at school and } \\
\text { teachers care about students } \\
\text { Personally }\end{array}$ & $\begin{array}{l}\text { Parents attribute children's } \\
\text { academic success to supportive } \\
\text { environment at school, } \\
\text { especially caring teachers }\end{array}$ \\
\hline & $\begin{array}{l}\text { Expectations are met } \\
\text { regarding Qur'an, Islamic } \\
\text { behavior, and Arabic } \\
\text { language } \\
\text { Parents are satisfied as long } \\
\text { as children are succeeding } \\
\text { Academically }\end{array}$ & \\
\hline
\end{tabular}




\begin{tabular}{|c|c|c|}
\hline $\begin{array}{l}\text { What social expectations do you have of } \\
\text { your Islamic school? }\end{array}$ & $\begin{array}{l}\text { 1. Children should learn to } \\
\text { interact respectfully with } \\
\text { parents, teachers, non- } \\
\text { Muslims, and each other } \\
\text { 2. Children should learn to } \\
\text { develop strong character traits } \\
\text { such as gratitude, kindness, } \\
\text { friendship, good citizenship, } \\
\text { mercy and compassion } \\
\text { Teachers should be role } \\
\text { model for children and } \\
\text { exemplify Islamic values }\end{array}$ & $\begin{array}{l}\text { Parents expect children to learn } \\
\text { how to develop their character at } \\
\text { school }\end{array}$ \\
\hline $\begin{array}{l}\text { Why do you have these social } \\
\text { expectations? Describe how your } \\
\text { background, values, faith, culture, and } \\
\text { anything else you would like to add, } \\
\text { influence your expectations. }\end{array}$ & $\begin{array}{l}\text { Instilled by parents } \\
\text { Example of Prophet } \\
\text { Mohammad } \\
\text { Teachers treat students } \\
\text { fairly, like their own children }\end{array}$ & $\begin{array}{l}\text { Parents acquired social } \\
\text { expectations from Islamic values } \\
\text { and influence of family }\end{array}$ \\
\hline $\begin{array}{l}\text { Are your social expectations being met? } \\
\text { If yes, how? If not, why not? }\end{array}$ & $\begin{array}{l}\text { Education and social circles } \\
\text { are good, so students want } \\
\text { to come to school } \\
\text { Happy that school sets limits } \\
\text { between boys and } \\
\text { Girls } \\
\text { Parents have to supplement } \\
\text { social needs outside of }\end{array}$ & $\begin{array}{l}\text { Parents are especially satisfied } \\
\text { with children learning how to } \\
\text { interact appropriately with } \\
\text { opposite sex. } \\
\text { Parents supplement children's } \\
\text { social needs outside of school. }\end{array}$ \\
\hline
\end{tabular}




\begin{tabular}{|c|c|c|}
\hline & School & \\
\hline $\begin{array}{l}\text { What cultural expectations do you have } \\
\text { of your Islamic school? }\end{array}$ & $\begin{array}{l}\text { To read, write and speak } \\
\text { Arabic and read and } \\
\text { understand the Qur'an } \\
\text { To experience and } \\
\text { understand diversity of beliefs } \\
\text { between people } \\
\text { Emphasis on Islamic culture }\end{array}$ & $\begin{array}{l}\text { Parents want their children to } \\
\text { learn about their own culture and } \\
\text { different cultures, although they } \\
\text { want the school to emphasize } \\
\text { Islamic culture. }\end{array}$ \\
\hline Why do you have these cultural & Cultural expectations come & Cultural expectation come from \\
\hline $\begin{array}{l}\text { expectations? Describe how your } \\
\text { background, values, faith, culture, and } \\
\text { anything else you would like to add, } \\
\text { influence your expectations. }\end{array}$ & $\begin{array}{l}\text { from Islam and upbringing } \\
\text { Important to introduce } \\
\text { different cultures to children } \\
\text { at young age } \\
\text { Want children to } \\
\text { communicate with family in } \\
\text { Arabic. }\end{array}$ & $\begin{array}{l}\text { Islamic teachings and parents' } \\
\text { own upbringing }\end{array}$ \\
\hline $\begin{array}{l}\text { Are your cultural expectations being } \\
\text { met? If yes, how? If not, why not? }\end{array}$ & $\begin{array}{l}\text { School meeting cultural } \\
\text { expectations } \\
\text { There's balance in cultures } \\
\text { at school } \\
\text { Expect religious culture to } \\
\text { be taught }\end{array}$ & $\begin{array}{l}\text { Parents feel that students' cultures } \\
\text { are well-represented at school and } \\
\text { that Islamic culture should be } \\
\text { emphasized over home country } \\
\text { culture }\end{array}$ \\
\hline
\end{tabular}




\begin{tabular}{|c|c|c|}
\hline $\begin{array}{l}\text { (subcategory of cultural expectation) } \\
\text { What religious expectations do you have } \\
\text { of your Islamic school? }\end{array}$ & $\begin{array}{l}\text { School responsible for } \\
\text { teaching Islam to children } \\
\text { To develop strong Muslim } \\
\text { Character } \\
\text { To be proud of their identity } \\
\text { as Muslims }\end{array}$ & $\begin{array}{l}\text { Parents want children to have a } \\
\text { strong Muslim identity }\end{array}$ \\
\hline $\begin{array}{l}\text { Why do you have these religious } \\
\text { expectations? Describe how your } \\
\text { background, values, faith, culture, and } \\
\text { anything else you would like to add, } \\
\text { influence your expectations. }\end{array}$ & $\begin{array}{l}\text { Influence of family's } \\
\text { Islamic values } \\
\text { Parent's responsibility to } \\
\text { ensure children have strong } \\
\text { foundation in Islam } \\
\text { Important to follow the } \\
\text { Sunnah of the Prophet (P) }\end{array}$ & $\begin{array}{l}\text { Parents acquired religious } \\
\text { expectations from Islamic } \\
\text { teachings that emphasize } \\
\text { education }\end{array}$ \\
\hline $\begin{array}{l}\text { Are your religious expectations being } \\
\text { met? If yes, how? If not, why not? }\end{array}$ & $\begin{array}{l}\text { Islamic education provides } \\
\text { good foundation for child } \\
\text { Arabic teaching methods and } \\
\text { curriculum should be relevant } \\
\text { for children in this society } \\
\text { School teaches children the } \\
\text { example of the Prophet (P) }\end{array}$ & $\begin{array}{l}\text { Parents believe Islamic school is } \\
\text { teaching children to be good } \\
\text { people. Parents stress importance } \\
\text { of relevant curriculum and } \\
\text { teaching methods. }\end{array}$ \\
\hline
\end{tabular}




\begin{tabular}{|l|l|l|}
\hline $\begin{array}{l}\text { What are your final thoughts on ways } \\
\text { that Islamic schools in general can better } \\
\text { meet your expectations? }\end{array}$ & $\begin{array}{l}\text { Parents must supplement } \\
\text { Islamic education with } \\
\text { opportunities outside of }\end{array}$ & $\begin{array}{l}\text { Islamic schools need to increase } \\
\text { resources to include extra- } \\
\text { curricular activities, teacher } \\
\text { certification and competitive }\end{array}$ \\
\hline & $\begin{array}{l}\text { School } \\
\text { Teachers are underpaid and } \\
\text { need to be certified } \\
\text { School is lacking in resources }\end{array}$ & \\
& & \\
\hline
\end{tabular}

\section{Interpretation of Findings}

To understand the expectations of teachers and parents, I proposed a study with two research questions in mind:

1. What are the academic, social, and cultural expectations that parents and teachers have of their Islamic schools?

2. To what extent are Islamic schools meeting the expectations of parents and teachers?

What follows is an explanation of what I learned from my findings.

For the first question, (What are the academic, social, and cultural expectations that parents and teachers have of their Islamic schools?), I discovered two main themes that emerged from the data. For the first theme, I found that teachers and parents expected children to be knowledgeable about Islam. For the second theme, I learned that 
teachers and parents expected children to apply their knowledge of Islam in their lives.

Next, I will illustrate the meaning of each theme by incorporating the data from the study.

\section{Expectation to be Knowledgeable about Islam}

One of the primary reasons that teachers work at Islamic schools is to teach children about Islam. Likewise, one of the main motives for parents to send their children to Islamic schools is to ensure that they acquire a basic understanding of Islam. This is not to say that teachers and parents expect children to focus solely on Islamic studies, although Islamic studies are key components of the Islamic school curriculum. As Shah (2016) stated in her explanation of a holistic Islamic education, for a student to be knowledgeable about Islam means to develop the whole person. That is, to be knowledgeable about Islam means to have an understanding of God's creation in its many forms including the spiritual as well as the physical and intellectual. Shah (2016) explained that Islam is a "philosophy of life encompassing the spiritual and the material, the corporeal and the divine." In other words, Islamic studies and general education are inextricably linked. As mentioned earlier, the first word of the Qur'an is Iqra, meaning "Read." The Qur'an continues, "Read in the name of thy Lord and Cherisher who created, created man out of a clot of congealed blood: Proclaim! And thy Lord is most bountifulHe who taught the use of the pen — taught man that which he knew not" (Qur'an 96:1). Muslims understand this verse as a directive by God for mankind to seek knowledge. In the next section, I will show how the data supported teacher and parent expectations for children to be knowledgeable about Islam in its broadest sense. 
One of the teacher participants, Khadija (pseudonym), who was also part of the management team, illustrated the expectation to provide a balanced education for her children that many participants echoed throughout the study. Khadija initially became involved in Islamic education when her son was ready to enter kindergarten. She explained, "We wanted to make sure we provided quality education but at the same time to make sure that we raised them as Muslims and teach them about the religion." Khadija wanted to provide an excellent academic education for her children as well as attend to their Islamic upbringing. This merging of spiritual and academic education exemplified the expectation that most participants in the study expressed. They wanted children to be knowledgeable about Islam as a religion that encompassed the divine as well as the practical matters of everyday life.

Aminah (pseudonym), a parent participant originally from Somali whose daughter interpreted for her during the interview, reiterated Khadija's expectation to educate the whole child. Aminah recounted how her academic expectations came from a background that valued a balance between Islamic education and general education:

She said she came from a background where education is strongly encouraged, and she's seen a lot of kids that had either the education that was strong in [general] education but not in their religion or Islam, or the other way without no education, and so she wanted her kids to have a balance. 
Aminah felt that WCIS offered her children an opportunity to acquire an evenhanded education that was equally strong in general education as well as Islamic studies, much like the education that she received as a child.

Several teachers expected their students to learn about Islam by learning Arabic. For example, a teacher participant, Zaynab (pseudonym), wanted to play a critical role in the religious education of her Muslim students through Arabic language instruction. She explained, "My language is Arabic, and my main thing is to help children to learn their religion." Zaynab described how her Arabic language skills provided the conduit to teach Muslim students about Islam, since the Qur'an and Hadith were written in Arabic. She felt like it was her responsibility to use her Arabic language skills to teach children about their faith in the original language of Islam.

Another Arabic teacher at WCIS, Aisha (pseudonym), stressed the importance of reading, writing and speaking Arabic, especially for the purpose of understanding the Qur'ran:

I expect them, before I finish the year, they have to know how to read perfectly. They know how to write perfectly. They know how to say what they want to say in my language that I'm teaching to them. And I like them to know how to write perfectly. Especially, most of the parents put their kids [in Islamic school] to learn Qur'an, to know how to read Qur'an in Arabic. Because of that, I expect from them to read perfectly, especially the Qur'an. 
According to Aisha, reading, writing and speaking Arabic with a high degree of skill were prerequisites for her students to be able to read and understand the Qur'an. Aisha mentioned that her high expectations for learning Arabic came from her desire to be instrumental in her students' acquisition of a difficult and important language to learn in order to increase their knowledge of Islam:

First, because here, the students that we have here in Islamic school, I don't want to say it's a lot of them, most of them or all of them, they don't know how to speak the Arabic. They don't know how to read the Qur'an, especially in Arabic. What I want, my expectation of this is that it's a different language for them, it's hard for them to know how to pronounce the letter or how to pronounce the word. I like to be involved in this so that they can learn this beautiful language.

Here, Aisha expressed a desire for her students to understand Arabic so they can read the Qur'an. For Aisha, playing a part in her students' acquisition of Arabic for the purpose of understanding the Qur'an constituted a noble cause on the part of teachers, especially teachers of Arabic and Qur'an. Aisha described Arabic as a "beautiful language" because it is the original language of the Qur'an. Muslims believe that the God revealed the Qur'an in Arabic, so the Arabic language is considered to be sacred. Therefore, teachers such as Aisha expect students to understand Arabic in order to be knowledgeable about Islam, since Arabic and Islam are so tightly interwoven.

Parents also stressed the importance of Arabic language skills as a means of gaining knowledge about Islam. For instance, Ruqayah (pseudonym), a parent 
participant, expected her children to learn about Islam by first developing their Arabic language skills: "Learn Arabic first, write, and read, and then they will build up first the language and then they will learn their religion." For Ruqayah, sending her child to WCIS guaranteed the acquisition of Arabic language skills, which she felt was a prerequisite to learning about Islam.

Parents mentioned other expectations, besides learning Arabic, that they wanted their children to fulfill in order to become knowledgeable about Islam. For example, Aminah mentioned that, along with proficiency in Arabic, she expected her children to have a well- rounded education that included general education in conjunction with a strong foundation in Islam:

She said with the general education, she would also want them to learn how to pray, how to read the Qur'an, how to fast, all the basics of Islam, as well as learn how to read and write Arabic and can understand it.

As with many of the parents, Aminah expected her children to have a comprehensive education that incorporated general education along with Islamic studies.

Other parents, however, prioritized Arabic language skills above all other parts of the curriculum. Fatima stressed the importance of her son learning Arabic so he could read and understand the Qur'an: "That's part of why he's in Islamic school is to learn the language and be able to read the Qur'an, you know. Obviously that's the most [important], to read and understand the Qur'an is my highest, you know, expectation." 
For Fatima, Arabic and the Qur'an went hand in hand. She expected her son to be knowledgeable about Islam by reading the Qur'an in its original language.

Unlike some participants who prioritized Arabic language skills for the purpose of reading Qur'an however, Khadija explained that her students' knowledge of Islam was not dependent on Arabic. Khadija described how she wanted her students to actually understand the language in which they were learning about Islam:

I feel like we need to teach these children, it's very important, being at an Islamic school, they need to know about their religion. And, in the past years when we first started, they were learning the religion by just memorizing it in Arabic where they couldn't even understand what they were saying. We decided, well, these children, they're leaving the school without really having a good understanding of their religion.

For her students to understand Islam, they had to understand the language in which the Qur'an was written. According to Khadija, rote memorization of Arabic taken out of its religious context failed to meet the expectation of teaching students about Islam. In order for students to acquire knowledge of Islam, Khadija expected them to understand the language of the lesson, whether in Arabic or English, rather than merely memorizing facts about Islam in a second language.

Sawda (pseudonym) echoed similar expectation as Khadija — the ability for students to understand the language in which they were taught their religion. Sawda explained, "I expect them to be able to read and understand Arabic. I expect them to 
memorize Qur'an. I expect them to learn, you know, important Islamic [concepts], and I expect them to be able to understand it." Sawda described how Arabic teachers, before they taught Islamic studies in English, were unable to teach students Islamic studies in Arabic in a way the students could understand. After the school policy changed, however, and Arabic speaking teachers began to teach Islamic studies in English, the students could understand the concepts in Islamic studies class and apply these lessons in their everyday lives.

Khadija explained how WCIS changed the language of the Islamic studies curriculum from Arabic to English in order to strengthen students' understanding of their faith:

You can't just memorize a bunch of things and not have a good understanding. So we changed our curriculum and we're following a program that was developed here for children who are born and raised in this country. And so, everything is taught in English so they can have a better understanding of the religion.

Khadija described how American-born students who learned about Islam in English rather than in Arabic would have a stronger understanding of their faith.

Along with the challenges that Arabic language acquisition posed, some parents in the study were faced with difficult decision of moving long distances in order to live closer to an Islamic school. Some parents went to great lengths to teach their children about Islam. For instance, a parent participant named Fatima (pseudonym) explained that she and her husband relocated to an area near WCIS for the sole purpose of providing an 
Islamic education for their child: "I actually moved here so I could put my child into an Islamic school. We felt that it was important that he be surrounded with a good foundation in Islam." As a convert to Islam and a parent of an only child, Fatima felt that it was her duty to provide a sound Islamic education for her son.

Other parents in the study made similar sacrifices to send their children to Islamic school. Aminah, similar to Fatima, moved to the West Coast in order to enroll her children in an Islamic school. Aminah's daughter translated for her mother:

My mom always wanted to bring her kids to somewhere where they can learn their religion, so one of her friends used to live here and told her about the school which is why we moved all the way across the country for it. And she says she's been happy with it so far.

The three thousand mile journey that Aminah took to enroll her children at WCIS was a testament to her personal commitment to Islamic education. Parents in the study expected their children to become knowledgeable about Islam, and they were willing to go to great lengths to fulfill their expectations.

Some parents in the study believed that exclusively sending their children to an Islamic school was the only way for their children to gain a sufficient understanding of Islam. Abdul Rashid (pseudonym), the only male parent participant in the study, explained that all three of his children had attended only Islamic schools: "It is important for me to give my children a solid foundation in Islam, Quran and the Arabic language." 
STAKEHOLDER EXPECATIONS OF ISLAMIC EDUCATION

Abdul Rashid felt personally responsible for the maintenance and continuation of his children's Islamic schooling so they could further their knowledge of Islam.

Not all parents were as rigorous as Abdul Rashid about their children's Islamic upbringing. A teacher participant, Zaynab (pseudonym), expressed dismay about Muslim children who lacked rudimentary knowledge about their own faith:

When I came and started with children, and I find out some of them, they're born Muslim, but they cannot even say the shahada (profession of faith). They cannot read, or they don't know anything about Islam because parent born here, they grow up here, and they don't know anything about their religion, or any basic thing, like the simplest thing about their religion. These kids going to get lost, so it's good to help whatever I can. I'm not like highly educated, but I can help with the basic thing and whatever I can. So it started from there, and I love teaching these kids, and I want them to understand their Qur'an and to understand their religion and to understand their language.

Zaynab's academic expectations focused on the ability of her students to learn the basic tenets of Islam. Clearly she felt it was her responsibility to help her students gain knowledge about Islam.

Zaynab elaborated on what she expected from her students: to be knowledgeable about the fundamental teachings of Islam such as morning prayers, evening prayers, asking for God's protection, feeling the words of the Qur'an while reading, feeling God's presence while praying, learning to fast and learning about making pilgrimage: 
STAKEHOLDER EXPECATIONS OF ISLAMIC EDUCATION

All this I bring it from Qur'an and Sunnah, and I try them with the kids, the basic things, the true things. Like, when you wake up, what's the $d u a$ (supplication) you say? When you go to sleep, what's the dua you say? How to have protection from Allah subhanahu wa taala (glory be to God)? When you ride your car, when you go out, when you go to a new city or a new country, all these simple things. And when you read the Qur'an at least just to feel it. When you stand for salah (prayer), like you're meeting with your God, your Creator, your Sustainer. Just stand between his hand and feel it, just calm down and do it and get your ajar (blessing) for that. To learn their salah, to learn their siyam (fasting), to learn small basic things about hajj (pilgrimage), and all these things like five pillars of Islam, six pillars of iman (faith). So it comes from Qur'an and Sunnah, from our deen (faith).

Zaynab expected her students to learn the five pillars of Islam (oneness of God, prayer, charity, fasting, and pilgrimage), as well as to believe in the six pillars of faith (belief in God, belief in the angels, belief in God's revealed books, belief in the prophets and messengers of God, belief in the Day of Judgement, and belief in divine predestination), all of which stemmed from her belief in the Qur'an and Hadith, the two primary sources of Islam, from which everything else flourishes, according to Islamic belief. Zaynab expected her students to be knowledgeable about Islam, and she detailed what she meant by Islamic knowledge. Furthermore, Zaynab felt that it was her duty to help her students acquire this understanding of their own faith. 
STAKEHOLDER EXPECATIONS OF ISLAMIC EDUCATION

Some parent participants felt as responsible as teachers regarding their duty to impart Islamic knowledge in their children. These parents shared the responsibility with the school to provide an Islamic education for their children with the Islamic school. For example, Fatima explained that she wanted to help her son, with the assistance of the school, to have a deeper understanding of Islam and to learn how to apply his faith to his life:

In terms of his faith, I want him to enhance his knowledge of his deen (religion), I mean I don't believe it's only the school's responsible to teach him about his religion, um it's my responsibility as his mother, but obviously I have him in Islamic school so that he will get that aspect of education as well, so it is important to me, and he is, he's very excited, he'll come home and tell me [Islamic] stories he thinks I don't know about, yeah I know that one (laughing). So, religiously, I think my expectation is that he learns more about his religion and how it interacts with life, and I think that is happening for sure.

Although Fatima played an important part in helping her son to nurture his Islamic identity, she also depended on WCIS to further develop his Muslim character. Fatima expected her son to be knowledgeable about his faith, and between the school's guidance and her own instruction, she made sure that he received a strong Islamic education.

Mariam was another parent participant who explained how she wanted her children to understand and identify with their Islamic faith: 
Out of the school, well I expect my kids to have Islamic values. It's very important honestly. I want them to know that you know, there is right and wrong. I want them to really understand their religion, and understand the history of it, and I want them to be proud of it, you know. Mariam expected her children to take the Islamic knowledge that they gained from WCIS and internalize these Islamic values. In addition, Mariam hoped that her children would feel honored to be part of their Islamic faith tradition.

\section{Summary of Expectation to be Knowledgeable about Islam}

Clearly, the teacher and parent participants in the study expected children to be knowledgeable about Islam. Knowledge of Islam included understanding the basics such as the five pillars of Islam and the six pillars of faith. Several participants believed that children should learn about Islam by reading, writing, and speaking about Islam in its original language of Arabic. Other participants felt that children should learn about Islam in their primary language in order to increase their understanding of Islam. Many participants expected children to acquire a balanced education that included Islamic studies and general education classes. Although some participants differed in their approach toward Islamic education, they all agreed in their expectation for children to be knowledgeable about Islam.

\section{Expectation to Apply Knowledge of Islam}

Along with the theme of participants expecting children to be knowledgeable about Islam, a second theme that emerged from the first question (What are the academic, social, and cultural expectations that parents and teachers have of their Islamic schools?). 
I learned that teachers and parents expected children to apply their knowledge of Islam in their lives. Islam is a proactive religion in that Muslims are expected to act on their faith. For example, the five pillars of Islam, which is the foundation of the faith, require Muslims to understand and perform each pillar. The first pillar, Shahada, is the declaration of faith. Muslims state that there is no god but God and Muhammad is the messenger of God. To be a Muslim, one must not only believe these words; they must also be uttered aloud. The second pillar, Salat, is the five daily prayers that Muslims must perform each day. To perform the prayers, Muslims must bow down in prostration to feel as close to God as possible. The third pillar, Zakat, is the charity that Muslims are required to provide regularly to those in need $-2.5 \%$ of one's assets annually. Other charity, called Sadaqa, is voluntary charity that Muslims are encouraged to provide year round. The fourth pillar, Sawm, is the fasting that Muslims must perform each year during the month of Ramadan from sunrise to sunset in order to empathize with people in need, ask God for forgiveness, and express gratitude to God. The fifth pillar, Hajj, is the pilgrimage that Muslims must make to Mecca in Saudi Arabia, the birthplace of Islam, in order to seek God's forgiveness and strive for self-improvement. Each of the five pillars requires Muslims to not only understand the tenants of Islam, but to put their faith into action in practical and consistent ways. Similarly, teacher and parent participants in the study expected children to not only understand their religion, but also to apply its principles in their everyday lives. For participants, it was not enough for children to be knowledgeable about Islam; children were expected to act on their faith in ways that demonstrated their lasting commitment to Islamic values. 
For example, Zaynab, an Arabic and Islamic studies teacher, described how she wanted her students to understand Arabic in order to read the Qur'an and improve the language skills that she believed were lacking in the current generation of Arabic language students at WCIS. Furthermore, Zaybab associated a lack of understanding of Islam with the possibility of falling away from the path proscribed in the scriptures. Conversely, an understanding of Islam, she believed, would lead to helping others:

As an Arabic and Islamic studies teacher, I like the kids to understand, like when they read the Qur'an, to understand it, to understand the basic things about their religion, and to be able to carry on, because I see this generation become weaker and weaker in the language and the Qur'an and understanding their, religion, plus whatever is going on now, so that makes them like go astray more. So I would like them to just understand the Arabic deeply and to understand their religion and to get it from there. To be able to read and understand and when they hold the Qur'an or want to help somebody else, to explain to them, like the right thing and the right thoughts about Islam.

Similarly to Aisha, Zaynab linked her students' knowledge of Arabic with their understanding of the Qur'an and Islam in general. She asserted that students who applied their Arabic language skills toward understanding the Qur'an were better equipped to apply their faith by helping others. On the other hand, she argued that a lack of understanding of Arabic and Qur'an resulted in her students losing sight of their moral compass. To be successful, Zaynab argued, students were expected to read and 
understand the Qur'an in Arabic, and be able to apply the contents of the Qur'an for the benefit of others.

Abdul Rashid's parents provided another example of real-life application of one's faith. Because of the high value that Islam places on education, his parents ensured that their ten children earned college degrees. Abdul Rashid explained, "My parents were hard working and made sure all of their ten children have university degrees. My religion makes it mandatory to strive for your best potential as Allah's representative on this earth." Between his parents and his Islamic faith, Abdul Rashid passed down his educational and religious ideals to his children who attended WCIS. He applied what he learned about the importance of education by providing a sound education for his own children. Abdul Rashid further explained how he wanted his children to learn how to be model citizens: "To teach my children how to be respectful and grateful, productive citizens of society, to treat and instill in them kindness, mercy and compassion." Abdul Rashid expected his children to be knowledgeable about Islamic virtues, and then to take this knowledge a step further by contributing to society through acts of good will toward others.

One of the main ideas that emerged from interviews with parents regarding their social expectations included their desire for children to develop their Islamic character at school, such as behaving respectfully toward others, being kind, showing gratitude, demonstrating good citizenship, and expressing compassion. 
Fatima described the social expectation for her son to learn how to relate to teachers, parents, and the opposite sex in a respectful manner:

My social expectations are that he will learn to interact with human beings. I like that he's learning to be respectful and to learn how men and women interact, and you know, teaching Islamically what we believe in terms of the men and the women interacting and being respectful of each other, and the hierarchy of respecting your parents, your teachers, and because whatever subject he's in, not just in Islamic studies is he learning about Islam, so I like that, that he's learning from a social perspective.

Fatima expected her son to not only learn about the Islamic position on respecting parents and teachers, and relations between men and women, she also expected her son to apply this knowledge across subjects and in a real-life context. Fatima wanted her son to learn about Islamic character, develop it within himself, and then interact respectfully and compassionately with others.

Aisha also expressed an expectation for her students to act on their Islamic teachings. She pointed toward the need for students to show respect for one another, especially their teachers:

I want them to behave nicely, like to behave, to really behave, like no bad words, to treat the others nicely, to be good with the others, to be helpful with the others. I like them to be kind, to work together, like no pushing, no screaming, to respect especially the teachers because a lot of kids they misbehave. The first thing and 
STAKEHOLDER EXPECATIONS OF ISLAMIC EDUCATION

the important thing is to behave with the teacher. This is most of the problem we face in the school, it's the behavior, like how they treat the teachers. They treat her like she is a sister for them. Or they treat her like another kid, they are playing with her.

Aisha emphasized the importance of teaching the Islamic value of respect to her students, especially respect for anyone who was older:

The most import thing to teach him is how to respect the older people, not only the teacher, even the parents, even the other people. Their son is older than you. You have to respect the older one. You have to respect him.

It was not enough for Aisha to teach her students about respect. She expected her students to demonstrate respect toward the school community, especially the older members.

Azrah was another teacher participant who expected her students to not only learn about Islam but also to implement Islamic principles in their daily lives. She explained, "I definitely have very high expectations when it comes to Islam and Islamic behavior." Azrah offered specific examples of Islamic behavior that she expected her students to put into practice:

The Salam Alaikum (Peace be upon you), the proper Islamic greeting, proper Islamic behavior, proper Islamic attire. They have to be very Islamic in the way they speak to each other and the way they sit and play with each other. So there's kind of a code of conduct that should be based on Islam and we have very high expectations Islamically. Prayer is prayed on time. We have a morning dua 
STAKEHOLDER EXPECATIONS OF ISLAMIC EDUCATION

(supplication) and a late afternoon dua. I mean just different things that we do to maintain that Islamic character, and it's very important to us as a school.

Language is a huge one. We have a very strict behavior and ethics code at the school and masha Allah (God has willed), the kids live up to it. And parents comment that they see the changes at home and they appreciate that a lot.

Azrah provided several examples about how she expected her students to apply their faith in their everyday lives, including greeting, dressing modestly, observing prayer in a timely basis, and using language in a way that exhibited Islamic manners. Azrah reported that students at WCIS applied these lessons at home, and their parents noticed improvements in their behavior.

Zaynab mentioned how she expected her students to act on their Islamic principles. For example, she explained that since Islam is a peaceful religion (the root of Islam means peace), Muslims should behave peacefully toward others, even if others respond unkindly:

It's a peace religion, and we should be this way. We should be nice to each other, nice to anybody around us, even somebody say something bad to you, like, just be gentle and they will understand one day. Just to do your religion, practice, love Allah, love your Prophet, love your neighbor, love your friend, your family. Respect all these values the Prophet taught us.

Zaynab expected her students to "do your religion", meaning to not only learn about Islam, but to practice their faith by loving God and all of His creation. 
STAKEHOLDER EXPECATIONS OF ISLAMIC EDUCATION

Mariam illustrated the journey she made as she learned about her faith as a child, applied the principles of Islam in her life as an adult, and finally, cultivated these Islamic values in her own children and students:

Whatever good things that I learned when I was little, of course I carried that with me because actually Islam also reinforces that, you know. To be honest, to be kind to other people, all these values that I was taught when I was little, these are values that in Islam, we try to foster in our kids.

Mariam's experience of learning about Islam, then practicing the virtues of honesty and kindness toward others, illustrated the expectation that participants shared regarding the application of Islamic values in everyday life.

Khadija described a scenario in which students were expected to integrate their Islamic knowledge into other classes. In the following example, students in health class at WCIS learned about the harmful effects of drug and alcohol.

Additionally, they learned about the Islamic position on drugs and alcohol and the reasons why they are forbidden.

Let's say they're teaching about drugs and alcohol, the affects and all that, then of course we will bring Islam into it and say, 'This is not allowed in Islam for all good reasons.' So those are the examples that I feel like Islam is brought into it.

Khadija illustrated how teachers integrated Islamic values across the curriculum. Students were expected to know where Islam stood on the use of drugs and alcohol. Furthermore, 
students were expected to apply this knowledge in their lives by actually abstaining from drugs and alcohol.

Mariam described how she expected her children to learn how to make sound decisions, to be self-reliant, and to learn how to contribute to society:

If these kids are not given the right tools, how to make the right decisions and how to live their life the proper way, you know, proper way in a peaceful way where they could actually contribute to the community. Well, if they don't learn those, if they don't get the right tools and the correct ones, how are they supposed to go out there and be and basically stand, stand up on their own?

Mariam expected WCIS to teach her children to be disciplined and resilient so they would be prepared to face challenges out in the world. For Mariam, Islam was a practical faith in which Muslims were expected to actively participate and contribute to the community.

\section{Summary of Expectation to Apply Knowledge of Islam}

In summary, participants in the study not only expected children to be knowledgeable about Islam, they also expected children to apply their knowledge of Islam in practical ways that benefitted others: students were expected to read and understand the Qur'an in Arabic, and be able to apply the contents of the Qur'an for the benefit of others; students were expected to be knowledgeable about Islamic virtues, and then use this knowledge to contribute to society through acts of good will toward others; they were expected to learn about Islamic character, develop it within themselves, and 
then interact respectfully and compassionately with others; students were expected to demonstrate respect toward the school community, especially the older members; they were expected to consistently use the Islamic greeting when addressing others, dress modestly, observe prayer in a timely basis, and use language in a way that exhibited Islamic manners; students were expected to practice their faith by loving God and all of His creation; students were expected to practice the virtues of honesty and kindness toward others; they were expected to practice what they learned in school regarding abstaining from drugs and alcohol; students were expected to face the inevitable challenges of the outside world; ultimately, they were expected to actively participate and contribute to the general community in positive ways that aligned with their Islamic faith.

\section{Extent Islamic School Met Expectations}

For the second question in my study, (To what extent are Islamic schools meeting the expectations of parents and teachers?), I discovered one overarching theme that emerged from the data - that of a supportive school community. I learned that the degree in which Islamic schools were meeting the expectations of parents and teachers depended on the level of support within the school community. Next, I illustrate the meaning of the supportive community theme by incorporating the data from the study. Then I show how Islamic schools are meeting expectations of teachers and parents by having a supportive community. Finally, I describe how Islamic schools are falling short of expectations due to areas of the school community that participants perceived as less supportive. 
The academic, social, and cultural expectations of teachers and parents were largely met by their Islamic school. Teachers and parents expected children to be knowledgeable about Islam. Furthermore, teachers and parents expected children to apply their knowledge of Islam in their lives. The extent to which expectations were met depended on the level of support that teachers and parents experienced within the school community. Generally, teachers and parents who felt supported by other teachers, parents, and other school leaders tended to state that their expectations were largely being met.

The data revealed that teachers and parents believed that a supportive school community helped children to be knowledgeable about Islam and to apply their Islamic knowledge in their lives. Throughout the study, teachers discussed how the school community worked together to support students who were struggling. Parents attributed their children's success to the supportive community at school, especially the caring teachers. Teachers' expectations were largely met due to the school community that worked together to support students, especially those who were struggling. Moreover, parent's expectations were generally met by the efforts of supportive teachers who helped students to succeed inside and outside of the Islamic school.

An example of a parent whose expectations were met is Fatima. She stated that she was highly impressed with the over-all academic quality of her son's education, particularly the teachers who made extra efforts to support her son in class: 
STAKEHOLDER EXPECATIONS OF ISLAMIC EDUCATION

My expectations, I think what we're getting is excellent. I'm very pleased with what we have here. The teachers care, they're empathetic, they want the kids to succeed, and if they feel like something's going on, they'll question it, they'll send me a note, they'll call me, say what's going on. You know, my personal situation, I'm divorced from his father, remarried, so he's gone through his own, you know, adjustments in that, and there is that genuine caring, loving environment that, as Muslims, I think is different.

Not only were the academic expectations of Fatima met at WCIS, the teachers exceeded what Fatima hoped for her son in terms of emotional support during difficult transitions in his life.

An example of a teacher whose expectations were met is Azrah. She illustrated how her social expectations were met by helping incoming students adjust to their new school environment. She explained how new students in particular required extra support to help them with their social adjustment:

We're still working with a lot of the kids, especially as new kids come into the school. We're always getting new students, and sometimes it's hard for kids to adjust, and you need to teach them those social courtesies, so to speak, so they can have a heathy relationship, and be a student, and be a friend, and just be their own individual and live their lives.

For Azrah, having a supportive school community included helping new students learn basic social courtesies that help them establish and maintain healthy, long- term 
relationships. Azrah's expectations were met with the help of her school community who helped incoming students to adjust by learning to put Islamic manners into practice.

Aminah, through the translation of her daughter, asserted that her expectations as a parent were fulfilled by WCIS because her children felt happy at the Islamic school. Aminah made the connection between her children's academic success and the supportive environment at school:

She knows that her expectations are being met because the kids are really happy to come here and they don't skip school very often. Like my brother skipped school today because he had a stomach ache, and all his friends asked me, 'Where's [son's name]?' She said if their education and their social circles are good, then they'll want to come to school.

The quality of her children's social environment was the indicator that Aminah used to gauge her satisfaction with her children's education at WCIS. Aminah's expectations were met by the supportive school environment at WCIS that contributed to her children's academic success.

Azrah strongly agreed that her expectations as teacher were met, stating that her expectations started high and remained high until her students worked through their challenges. She shared a recent experience with a struggling student who finally started to believe in his own potential after years of discouragement from teachers at a different school: 
STAKEHOLDER EXPECATIONS OF ISLAMIC EDUCATION

He says, 'I can't do it, I'm stupid, I'm slow.' And he says, 'That's what they told me at my old school. I was in special education.' I'm like, 'Why? What makes you special? Why would they do that to you?' And he's like, 'I don't know. It's because they thought I couldn't read.' 'Well can you read?' 'And he goes, 'well yeah.' And so he's been a struggle, but he got a B on his last test. And for me and for him, he couldn't believe it. And I was like, this is what hard work does. So I never change my expectations. You know, sometimes I have been accused of having too high of expectations, and I'll say, you just watch, by the end of the year. Let them cry, let them struggle, let them come to me for help. Let them come to you for help. But at the end of the day, they will be better for it, and they really are.

The story that Azrah shared about the academic and emotional transformation of her "slow" student into a hard-working successful student was a testament to the benefit of members of the school community working together to support struggling students.

Khadija also emphasized the importance of the school community working together to support students who were struggling. She described her satisfaction with the math program at her school, as well as the challenges of the science program, explaining that her math and science expectations were fulfilled:

I feel like our math program was quite strong. For years though, science was a great challenge because I feel like we didn't have the resources, and science is such a hands-on subject, and we've always struggled in that area. I mean, right 
now, especially in our middle school, we have a wonderful science teacher, and we are trying to bring as much additional resources to get our children excited in that subject, which is working well.

The academic expectations of Khadija were being met, particularly in the subjects of math and science. She mentioned that the science teacher was largely responsible for the success of the science program at WCIS. Khadija's expectations were met due to efforts by a supportive administration that retained strong science and math programs and teachers as well as provided hands-on resources for the children.

One way that Zaynab's expectations were met was by supportive parents who were not necessarily practicing Muslims, yet their children attended an Islamic school so they could benefit from a religious environment that they may be lacking at home. Zaynab expressed her appreciation for these parents who enrolled their children in the Islamic school in spite of their own religious limitations: "Some parents are not religious at all, or not practicing. They still bring their kids because they want them to be better than they are." These parents wanted their children to be knowledgeable about Islam, but they may not have the ability to provide adequate religious instruction and reinforcement for their children at home. Zaynab's expectations were met due to the support for Islamic education that parents provided their children in spite of their own shortcomings.

Another example of expectations being met due to the supportive school environment related to the issue of male-female relations. Fatima felt supported as a parent when it came to her son's religious instruction on how men and women should 
STAKEHOLDER EXPECATIONS OF ISLAMIC EDUCATION

interact. Fatima stated that WCIS had fulfilled her social expectations, especially the way her son learned to behave respectfully toward members of the opposite sex:

Those social expectations are being met here. I like that he's learning to be respectful and to learn how men and women interact, and you know, teaching Islamically what we believe in terms of the men and the women interacting and being respectful of each other.

Fatima was satisfied with the way WCIS equated the Islamic relationship between men and women as an act of respect. She expected her son to be knowledgeable about Islam and to apply that knowledge in his life. An important part of Islamic knowledge concerns male-female relations. Not only must Muslims understand this concept, they must apply this knowledge by behaving respectfully and modestly toward members of the opposite sex. Fatima's expectations were met on this issue because she felt supported by the school's environment in which boys and girls practiced behaving respectfully toward each other.

Mariam's expectations were met by the supportive cultural environment of her diverse classroom. In her classroom, students interacted with classmates from a variety of backgrounds. They got to know each other and appreciated each other's differences in the process. Her students learned that, in spite of their differences, they shared a common faith that bound them together as members of the human family. Mariam explained how WCIS provided a diverse cultural platform on which to emphasize the commonality of Islam to her children: 
In the Islamic school, we have kids from all over the world, and they have different culture their parents taught them, and I want my kids to know that although we are all different, we share in common with Islam. And our culture should not divide us. It actually makes us more colorful, you know, when we see different people and live with them and when you get to know other people from other culture, then you start to know those people, not just whatever you hear on the TV about how, the bad things about them, but you have to really appreciate people, who they are.

Mariam pointed out how exposing students to diverse cultures can help students to get to know and understand different people rather than having to depend on unreliable sources for cultural information. Mariam's expectation for her students to be knowledgeable about the diversity and commonality of Islam was met due to a supportive school community that practiced a well- known verse in the Qur'an: "O mankind! We created you from a single pair of a male and a female, and made you into nations and tribes, that ye may know each other and not that ye may despise each other" (Qur'an 49:13) meaning that, according to Islamic belief, people were created differently in order to get know one another and understand each other. Mariam illustrated how the Islamic school nurtured and supported the rich diversity of its Muslim community.

Another teacher whose expectations were met was Sawda. She expressed how gratifying it felt to witness her students develop into confident Muslims as a result of the solid religious foundation that the school provided: 
STAKEHOLDER EXPECATIONS OF ISLAMIC EDUCATION

My expectations are met on that level. I really feel like, my daughter's in eighth grade this year, so she's graduating, and I feel like she has a really strong Muslim identity from pre-school to eighth grade. The eighth graders that I'm teaching, I taught in kindergarten, so to see that progression and that transition and see the kids that they've turned into, there's nothing more rewarding than that.

Sawda, who is also a parent of a student at WCIS, witnessed the long-term development of her daughter's Muslim identity over the years. Sawda's expectations were met for her daughter and her other students to be knowledgeable about Islam and to apply their knowledge toward acquiring a strong Muslim identity that allowed them to flourish. The supportive school community at WCIS was responsible for successfully instilling a strong Islamic character in their students that allowed them to thrive.

Fatima expressed gratitude for the solid base that her Islamic school provided for her son.Her expectations for her son to get off to a good start in life with the help of a strong Islamic education were met due to the supportive environment at WCIS:

I'm thankful for Islamic education. It really is a blessing in my life and for my family, for my son cause I feel like it provides, as a revert, as a working mom, it provides things that I am not able to provide. It supplements what I'm able to do, and it provides what I hope to be part of a good foundation for my son's life. I wouldn't do it any other way.Certainly, I have lots of friends that homeschool, or I have friends that do have their kids in public school, but most of them are stayat-home moms that can be there to pop in on the class, or they have the patience 
STAKEHOLDER EXPECATIONS OF ISLAMIC EDUCATION

to do home schooling (laughing) you know, that's not me (laughing), so you know, I'm thankful that it's an option. It's a good option and I'm happy how it's been.

The Islamic school proved to be an ideal fit for Fatima and her son by filling in the critical gaps that might otherwise have occurred with a working mother who converted to Islam and needed the extra support that WCIS offered.

Mariam described how the religious curriculum at WCIS prepared her child to learn how to make sound decisions, to be self-reliant, and to learn how to contribute to society:

Yeah, I do feel like the school is meeting the religious expectations of my child. Because they teach them some Islamic studies, you know, how to behave, and what is sin, and what are the things that is not acceptable, like you know, this insha Allah (God willing) will help my children to really, once they go out there, hopefully to be strong enough, to stand on their own, you know. I wouldn't find it anywhere else, and I am happy to actually send them to this school because I know that whatever they would teach them in the Islamic areas, it's the best that I could probably get anywhere. And I want my children being taught the right Islam. I do not want my children to learn, pick and choose what your children want to learn. Teach them the right one and it's really up to them, at the end of the day, they're going to live their lives, and they're going to have to make those decisions on their own, you know. But I think giving them the right tools will 
STAKEHOLDER EXPECATIONS OF ISLAMIC EDUCATION

allow them to do that. If these kids are not given the right tools, how to make the right decisions and how to live their life the proper way, you know, proper way in a peaceful way where they could actually contribute to the community. Well, if they don't learn those, if they don't get the right tools and the correct ones, how are they supposed to go out there and be and basically stand, stand up on their own? And know at least when you believe something, you stand for it, you know, and as long as you have the truth, that's the best tool you have. So, yeah, I feel like this school actually teaches my kids the right way, I would say the Sunnah, which is very important for me because I do not want my kids to get confused, you know. They go out there, and then I want them to know what is wrong and what is right, you know, in Islam, what is expected of you, and where are the gray areas, and it's up to them, you know.

Mariam clearly believed that WCIS taught her children the "right Islam" that prepared them to be disciplined and resilient when they would eventually face challenges out in the world. Her expectations for her children to be knowledgeable about Islam and to apply their knowledge in a real world context were fulfilled. Mariam expressed total confidence in her Islamic school to continue supporting her children on their Islamic journey.

\section{Summary of Met Expectations}

The degree in which Islamic schools were meeting the expectations of parents and teachers depended on the level of support within the school community. Examples of community support that emerged from the data included: teachers who offered children 
emotional support during difficult transitions in their lives; teachers who supported incoming students as they adjusted to their new school by incorporating Islamic manners; teachers who supported children by creating a happy learning environment for them; teachers who collaborated to support struggling students; school leaders who supported strong math and science programs; parents who supported their children's Islamic education in spite of their own limitations; teachers who supported a learning environment where boys and girls learned to behave respectfully toward one another; staff that supported the diversity of its Muslim community; teachers who supported students to develop a strong Muslim identity; teachers that supported parents who were struggling to fill gaps in their children's Islamic education; and finally, teachers who supported parents who wanted their children to apply their Islamic knowledge in a real world context.

\section{How Islamic Schools are Falling Short of Expectations}

Although the expectations of teachers and parents were largely met by their Islamic school, the data revealed some areas where the Islamic school fell short of meeting expectations. Teachers and parents who felt unsupported to some degree by their school community tended to state that their expectations were not being met.

Next, I will explain the areas where the Islamic school did not meet some of the expectations of teachers and parents.

One area where some teachers' expectations were not met was in Arabic language class. Islamic schools teach Arabic to students for the purpose of reading and 
understanding the Quran and Hadith. Arabic language skills are important to Muslims since the Qur'an was revealed and written in Arabic. Teachers expected students to learn Arabic so they would be knowledgeable about Islam. It is a widely accepted practice for Muslims to read and understand the Qur'an in its original language. However, some students struggled in Arabic class, as Arabic is not their first language. Regarding these struggling students, some teachers felt unsupported in their effort to teach Arabic to students whose parents did not speak Arabic and therefore, they could not assist their children in Arabic language at home. For example, Aisha believed that her expectations as an Arabic teacher were largely unmet due to parents who did not speak Arabic and were unable to help their children study at home:

Most of the parents here, they don't know how to speak the language. I have to work by myself, to do it by myself. No one can help them at home, to do it at home, especially the homework, or a test or anything.

The expectations related to students' Arabic language skills were largely unmet by Aisha because she was unable to rely on parents for homework support due to their limited or even non-existent Arabic language skills. Aisha felt that her students' Arabic language development was solely her responsibility. In order for her students to learn Arabic so they could be more knowledgeable about Islam, Aisha needed the support of parents. Some parents were unable to provide Arabic language support to their children who struggled with the language. This resulted in the unmet expectations of some of the 
Arabic language teachers in terms of children gaining knowledge of Islam by applying Arabic language skills.

Limited parental assistance with Arabic language skills was an issue for some of the teachers in the study. Like Aisha, Zaynab experienced a similar lack of parental involvement with her Arabic language students. Zaynab stressed the importance of parents providing extra academic support to children who were struggling with Arabic:

The house needs to help. Parents need to help. It's like very main role because the kids like learning all the subjects in the school and they cannot focus on one. If they just take it [Arabic] in school, and they go home and nobody help them at home because their parents are busy with work, busy with everything, and nobody will help that child, so that child will still struggle. They can do something, but at the same time, if there's no help, no practice, nothing, it's [Arabic] going to be still very weak.

Unlike Aisha who could not rely on parents to assist their children with Arabic due to their own lack of Arabic language ability, Zaynab expressed frustration over parents' unwillingness to help their children with Arabic homework due to their busy schedule. Zaynab's expectations for her students to learn Arabic in order to increase their knowledge of Islam were unmet due, in part, to parents who did not support their children's Arabic language needs. These parents, according to Zaynab, were either too busy or lacked sufficient Arabic language skills to assist their children at home. 
STAKEHOLDER EXPECATIONS OF ISLAMIC EDUCATION

Along with parental responsibilities to support their children's Arabic language development, Zanab mentioned that Arabic teachers have an obligation to learn the most effective methods to teach the language:

Have new ways of teaching this language, it will help. New methods maybe, experiences. And I think teachers are very very important role, to be like really good at this, very professional in teaching this language because it's a hard language, not that easy, so they need like really good, professional to do that job. It's like many many schools do it together and work on it.

Zaynab stressed the importance of the school community collaborating to develop the most effective approaches to teaching Arabic language. Teachers need the support of their school community to learn the best ways to teach Arabic so students can apply their Arabic language skills toward increasing their knowledge of Islam.

Aminah offered a different perspective on the Arabic language issue at WCIS. While most parents appreciated the recent change from Islamic studies classes taught exclusively in Arabic to classes taught in English as well as Arabic, Aminah preferred the more rigorous Arabic-only classes for her children. Aminah mentioned, through her daughter who interpreted, that she preferred the school's previous Arabic curriculum that was more challenging and resulted in stronger Arabic language skills for her children:

One thing that she would improve on is Arabic studies. When me and my two sisters used to come here several years ago, Arabic studies were a lot more intense, and all three of us could speak and write and read Arabic, but a couple 
STAKEHOLDER EXPECATIONS OF ISLAMIC EDUCATION

years ago they switched the curriculum to half English, half Arabic books to make it easy for the kids, but I think that caused the kids to focus on the English side to make it easier for themselves, not to challenge themselves, so we noticed that the level of Arabic studies have kind of dropped a bit, so that's something that she would like to improve.

Unlike some of the other parents who welcomed the change to a more flexible Arabic curriculum, Aminah understood the value of a strict, Arabic-only curriculum that resulted in her children's highly developed Arabic language skills. Aminah felt more supported by the Arabic teachers while her children learned Arabic using a more rigorous approach. However, Aminah believed that her younger children who were instructed in the halfEnglish/half-Arabic class were not gaining sufficient Arabic knowledge, so her Arabic language expectations for her younger children were unfulfilled.

Along with a lack of parental support at home with their children's Arabic language skills, teachers also mentioned a deficiency of parental support at school for conferences, volunteering, meetings, and gatherings. For example, Zaynab stated that her social expectations were unfulfilled due to a general lack of parent involvement:

I don't see the parents. I don't see them, and I wish parents will come forward. Like we have parent-teacher conference a couple of weeks ago. Four, five families showed up, and I felt like so sad. I know most of the parent are working, but still, like, this is your child. This is your life, and I wish to see the parents more, to communicate more, to understand what's going on in their lives. That 
STAKEHOLDER EXPECATIONS OF ISLAMIC EDUCATION

will help their children too, if they have this social mingle together. I think that will help them and help their children. But some people, I think they are too busy in their life, they are too busy, too expensive, so the parents are so busy. And I'm afraid for the kids, what's going to happen to them. That's the parent's life, and what's going to happen to them a few years ahead. So we need more of that, to see each other, to have the parents come and work with the teacher. Have their hands to help the children.

Zaynab pointed to a general lack of parental involvement throughout the school community. Furthermore, Zaynab was concerned about the future consequences of parental absence in the lives of their children at school. Zaynab suggested that without the support of their parents, without "their hands to help the children," children would be at a disadvantage. Parents who supported their children by showing up for school events may be more likely to understand their challenges and help them succeed in school.

While some teachers in the study felt a lack of support from parents concerning Arabic language assistance, attending conferences, and volunteering, likewise there were parents who felt a lack of support from teachers regarding the use of up-to-date technology in the classroom as well as using modern teaching techniques. For example, Ruqayah suggested that there was room for improvement regarding the traditional style of teaching at WCIS that she said should be more progressive:

They can improve their style of teaching, like they can maybe use some other things. You know, they don't use a projector. The kids want something different. 
It's not just like lecture style. You know, I talked to the principal the other day, and I said my daughter, she's getting bored. She's very smart. She loves to do her homework. She's like on exams, always As, but she's getting bored because she's learning the same style I used to learn when I was in my country, and she sees her siblings when she comes home because the other ones, they go to public school, and they talk, and she knows now the difference, even though she started here like as a preschooler in this school.

Although Ruqayah was satisfied with the academic performance of her daughter at WCIS, she was clearly concerned with the traditional instructional approaches that may not fully engage the students. Ruqaya was worried that her daughter would lose interest in learning due to an unstimulating lecture style from teachers. Ruqayah verbalized her need for support on this issue of using modern teaching techniques in the classroom. Parents' expectations were unmet when their children were unsupported by outdated teaching styles and classrooms that were unequipped with modern technology.

Another area where participants' expectations were unfulfilled related to unsupportive behavior between students. Aisha stated that her social expectations of students treating each other as family members "are not met exactly" due to cliquishness between students from different backgrounds:

From the students, as you can see, from different cultures, from different countries, some of them, they don't get together, like they fight, they argue together, they say bad words. Some of them, they are friends, they don't want 
STAKEHOLDER EXPECATIONS OF ISLAMIC EDUCATION

anyone to get involved with them. They want to keep them away, just only their group.

For Aisha, some of her students fell short of her social expectations due to their exclusionary behavior toward one another. Supportive relationship between students, according to Aisha, would resemble students who treated each other more like family members rather than adversaries. Furthermore, for students to be knowledgeable about Islam and apply this knowledge in their lives would require that they understood the emphasis that Islam placed on inclusiveness and behave in a caring, supportive manner toward each other.

Aisha elaborated on the lack of support that some students showed each other as well as their teachers and parents. She expressed her disappointment in the lack of respect, which is antithetical to Islamic teachings, she perceived between some students, teachers, and parents:

The kids are not meeting those expectations because here is a free country, like even they can talk to the parents freely. They talk to their parents like they are talking to their brother or sister. It's no respect because this is their culture and our kids they take it from them. If the mom says 'shut up' it's allowed for the kids to say the same thing. It's no respecting for the older one. I try to make them understand. Most of the teachers now they treat the kids like they are their friend.

Aisha mentioned that one of the main values emphasized at WCIS was respect, especially respect for older people such as parents and teachers. However, Aisha noticed that some 
students showed a lack of respect for teachers as well as parents at WCIS. According to Aisha, this general lack of respect was a consequence of some students, parents, and teachers being unsupportive of each other's Islamic roles and their boundaries. If these students, parents, and teachers were more supportive of one another, Aisha's expectations of students being knowledgeable about Islamic manners surrounding respect and applying this knowledge may have been fulfilled to a greater degree.

Another example that illustrated how some teachers experienced a lack of support occurred when female students were instructed by their school community to wear a hijab (head scarf), yet some parents did not reinforce this religious requirement at home. Azrah explained, "I think some of the things that are difficult are for example, a hijab is mandatory for fifth grade and up and if you have a mom that doesn't wear hijab, so that causes a conflict." Azrah suggested that students who hear one message at school and a different message from home regarding the hijab were sometimes confused about the meaning of the message. Furthermore, she indicated that the Islamic value of modesty that was emphasized at WCIS should be reinforced by parents at home so students would have a clear understanding about the reasons for a hijab. One way that teachers expected students to be knowledgeable about Islam concerned the concept of modesty, and wearing hijab was a way for female student to apply this knowledge of Islam. Some teachers felt unsupported by the parents who did not reinforce the Islamic principle of the importance of hijab. 
A final area where expectations were unfulfilled related to a lack of support from some key stakeholders regarding future growth of the Islamic school. For example, Khadija, a teacher who was also on the management team, expressed frustration over the lack of support from stakeholders, such as some board members, when it came to creating a vision for growth within the Islamic school:

I would say my expectations, it's been challenging actually. It's like having this vision for the school to grow, and there are other stakeholders, board members, you know, others who are involved in helping the school grow, and sometimes that has been challenging to say, okay, we have this vision, let's do this, let's move forward and help the school grow, and sometimes I feel like they tie my hands and throw me in the ocean and tell me, 'Swim'. That's what's been the most stressful thing. When it comes to the actual day to day running of the school and working with the students and the teachers and even the parents, but I want to see, okay, where's the school headed? I mean, are we going to stay where we are right now? Or do we have a vision to help it grow? And so that's where it's been challenging for me and I feel like I haven't been able to make much progress because of the other stakeholders involved.

Khadija remarked on the supportive relationships between parents, teachers and students. However, she conveyed her frustration over a lack of support from some other key stakeholders regarding the future growth of the school. As with the other teachers, Khadija expected her students to learn about Islam and apply their knowledge of Islam in 
their daily lives. In her role as a school leader, however, Khadija felt the responsibility of creating a vision for the school to improve and expand in order to provide the best possible environment for students to learn about Islam and apply their faith. She felt disappointed when some key stakeholders, on whom she depended for financial and moral support, failed to collaborate on a plan for school development.

\section{Summary of Falling Short of Expectations}

The degree in which Islamic schools were falling short of meeting the expectations of parents and teachers depended on the level of support within the school community. Examples that illustrated the school community's lack of support that emerged from the data included: some teachers who felt unsupported by parents who did not provide Arabic language support to their children who struggled in Arabic class; some Arabic teachers who felt unsupported in being trained on the best ways to teach Arabic; some parents who felt unsupported in their effort to ensure their children learned Arabic sufficiently in a half-English/half-Arabic class; some teachers who felt unsupported by parents who failed to show up for conferences, volunteering, and other school gatherings; some parents who felt a lack of support from teachers who failed to use modern teaching techniques and up-to-date technology in the classroom; some teachers who felt unsupported by students who practiced exclusionary behavior with other students from different backgrounds; some teachers who felt unsupported by other teachers, parents and students for showing a lack of respect toward one another; some teachers who felt unsupported by parents who failed to reinforce Islamic behavior at 
home; and finally, some school leaders who felt a lack of support from major stakeholders when it came to creating a vision for school growth.

\section{Bracketing Out the Researcher's Experience}

Creswell (2013) stated, "To fully describe how participants view the phenomenon, researchers must bracket out, as much as possible, their own experiences." As a long-term teacher and a parent affiliated with an Islamic school, I became interested in the experiences of other teachers and parents in their Islamic schools. I wanted to understand what they expected from their Islamic school experiences. Furthermore, I wanted to know if their expectations were being met. To find out, I interviewed several teachers and parents that were affiliated with a different Islamic school than the one where I taught and where my children attended.

My own educational experience as a young student began in the public school of a rural logging town on the West Coast. Most of my classmates came from white working class families. Drop-out rates were high and college-bound students were few, so my parents decided to send me to a Catholic boarding school that had better odds. For the first time, I was exposed to international students as well a variety of local students whose families had high academic expectations. I was also surrounded by teachers who set the bar high for students in terms of academic standards and behavioral requirements. As a result, everyone in my class graduated, and nearly all of my classmates attended four-year colleges. Going from one extreme to the other, from my low performing elementary and 
middle school to my private college prep school, made me aware of the effect that parents' and teachers' expectations had on students.

After graduating from college, I accepted a teaching position in Japan where I was exposed to a new level of cultural expectation. After a demanding day at school, my Japanese students continued their rigorous education until late into the evenings, attending extra-curricular activities and schools such as the one where I taught English. My students returned home at nine or ten o'clock at night, studied for a few more hours, then woke up early the next morning to repeat this arduous schedule for the remainder of their years at school. During the two years that I taught in Japan, I often reflected on the cultural expectations of discipline and excellence that permeated the lives of Japanese students.

Upon completion of my teaching contract in Japan, I traveled to Northern India to the Muslim-majority state of Kashmir where I met and married my husband. During the year that I lived in Kashmir with my husband's family, an insurrection between Indian government forces and Kashmiri separatists erupted, resulting in frequent closures of the local school system. Throughout my stay, I observed the effect that school closures had on children and their families. Again, the idea of expectations came to my attention as parents, who had envisioned their children achieving academic excellence, endured daily curfews and school closures. This political turmoil and educational instability continued long after we departed from Kashmir and settled on the West Coast. Consequently, an 
entire generation of Kashmiri children was deprived of a basic education and the opportunities that came with it.

My husband and I settled in the same logging town where I grew up in order to live close to my family. By this time, the logging industry had vanished and the mills had shut down in our town. Our school district was one of the lowest performers in the state. By this time, we had three children who were approaching school age, so we had to make a decision to either leave my family and hometown to live closer to better schools, or remain in my hometown with my family and enroll our children in the same school I had attended as a child. We decided to uproot and move to a city that was closer to my husband's job, a mosque, and an assortment of higher performing schools. There was a teaching position available in a nearby Islamic school, and since I had recently converted to Islam, this seemed like a good opportunity to enroll my children in a good school that reflected our Islamic values as well as return to the teaching profession.

Our three children have attended Islamic school since pre-kindergarten. Two have graduated and are currently attending college while my youngest is in her junior year of high school. This is my sixteenth year of teaching at an Islamic school. My own children, as well as the students that I have known since pre- kindergarten and now attend college, have inspired me to conduct this study about educational expectations. As a parent of children who spent the past fifteen years at an Islamic school, I wanted to know about the impact that an Islamic education makes on children. As a long-term teacher at an Islamic school, I wanted to understand how my students experienced their Islamic education. As 
both a teacher and parent, I wanted to know if teaching and pursuing an Islamic education was worth the time, effort and expense.

\section{Experiences of the Participants}

Not surprisingly, the teachers had different expectations than the parents in the study. The degree to which their expectations were met varied as well. For example, teachers expected students to succeed in the outside world through fostering an Islamic identity and providing them with an academically rigorous education. Parents, on the other hand, expected their Islamic school to provide an optimal education experience for their children by balancing lecture style with a creative learning environment that included small class sizes for one-on-one help.

Teachers mentioned ways to better meet their academic expectations such as encouraging the school community to work more closely together to support students who are struggling, especially with Arabic language skills. Parents, however, were largely satisfied with their children's academic achievement, attributing their children's academic success to the supportive environment at school, especially the caring teachers. Parents mentioned that their expectations were met particularly in the areas of Qur'an, Islamic behavior, and Arabic language.

Teachers expected socially healthy relationships at school to include clear communication and respectful relationships within the school community. Parents expected their children to development their character by learning to respect others, demonstrating gratitude, showing kindness, learning how to be a good friend, developing 
good citizenship, and showing compassion toward others. Furthermore, parents expected teachers to be positive role models for children and exemplify Islamic values.

Teachers expressed a need for more balance and support within school community before their social expectations could be fully met. For example, some teachers pointed to a general lack of parental involvement in school and the need for some students to learn social courtesies that foster healthy relationships. Parents were especially satisfied with the way their children learned how to interact appropriately with opposite sex. However, parents mentioned that they needed to supplement children's social needs outside of school with clubs such as sports, art, and music.

Teachers expected students to understand their own and each other's cultural identities. Moreover, teachers observed that their students were often caught between their parents' culture and American culture. As a result, teachers expected their students to prioritize their Muslim identity since it was the common denominator within their students' various cultural backgrounds. Parents wanted their children to learn about their own culture and different cultures, although they wanted the school to emphasize Islamic culture in particular. For example, parents expected their children to experience and understand the diversity of beliefs between people, but they wanted the school to emphasize Islamic culture by focusing on reading, writing and speaking Arabic as well as reading and understanding the Qur'an.

Teachers described how their cultural expectations were met due to the high level of respect for cultural heritage that was demonstrated within the school community. 
Teachers mentioned, for example, that although their students were from many cultures, they accepted each other. Furthermore, teachers pointed out that they had high morale and enjoyed working together at school. However, teachers remarked on the need for students to have Arabic language support at school and at home. Parents felt that students' cultures were well-represented at school and that Islamic culture was emphasized over home country culture.

Regarding religious expectations, a subcategory of cultural expectations, teachers expected the school community to apply the Islamic values that were taught at school. For example, teachers expected students to demonstrate their faith at school. Additionally, teachers expected parents to support Islamically acceptable behavior that the school emphasized. Finally, teachers expected themselves to model Islamic behavior to their students. Parents held the school responsible for teaching Islam to their children, to help their children to develop a strong Muslim character, and to instill a sense of pride in their identity as Muslims.

Some teachers mentioned the need for parents to better reinforce Islamic behavior that was taught at school. However, teachers indicated that students had a strong Muslim identity and that Islam was integrated into other school subjects. Parents believed that their school was providing a good foundation for children by teaching students to follow the example of Prophet Muhammad. However, parents stressed the importance of teachers using a relevant curriculum and updated teaching methods, especially in Arabic and Islamic studies classes. 


\section{Limitations of Study}

At the conclusion of every study, it is important for the researcher to carefully consider the potential weaknesses of the study. Clark and Creswell (2010) stated, "researchers provide a critical evaluation of their studies by advancing the limitations or weaknesses of the study that may have affected the results" (p. 356). The possible weaknesses of my study included a limited number of participants, time constraints, unfamiliarity of my participants, and bias of the researcher.

\section{Limited Participants}

Although ninety students were enrolled at WCIS and fourteen teachers were employed at WCIS at the time of my study, it was challenging to find five teachers and five parents who were willing to participate in the study. With the generous support of the principal, I screened and interviewed the ten participants over a span of three months. Although my pool of participants was limited, I was able to conduct more detailed and thorough interviews with fewer participants. As Seidman (2013) stated, "the method of in-depth, phenomenological interviewing applied to a sample of participants who all experience similar structural and social conditions give enormous power to the stories of a relatively few participants" (p. 59). The limited number of participants in my study allowed for their few, yet powerful, stories to emerge.

\section{Time Constraint}

I conducted the study during spring term, so I had a brief amount of time to send and collect my surveys, select subjects and schedule and interview participants before 
summer break. I was working full-time throughout my study, as were many of my participants, so it was challenging to find a common time to meet and conduct 90-minute interviews. The interviews took place in or near the school where my participants were affiliated, which was approximately a thirty minute drive from the school where I worked. I tried to accommodate the scheduling requirements of my participants as much as possible, which meant meeting during after school hours, in the middle of the school day during teacher planning times, and occasional weekends. All of my participants had work and family responsibilities, so it was sometimes difficult to find a mutually available 90-minute time slot in which to conduct in-depth interviews.

Throughout the interview process, the data that I gathered was so captivating that I often wished that we had more time to talk about their experiences with Islamic education. However, I soon realized that the more data I collected, the more data I had to analyze later. Seidman (2013) stated, "as they begin to work with the vast amount of material that is generated in in-depth interviews, they will appreciate having allotted a limited amount of time to each" (p. 24). I learned to appreciate the time constraint of 90minutes that otherwise may have produced an unmanageable amount of data to analyze within my limited time frame.

\section{Unfamiliarity of Participants}

Originally, I had planned to conduct my study with participants from the same school where I taught. Originally, I believed that I could distance myself from my participants sufficiently to conduct a study with minimal bias. Later, I agreed to change 
my focus to a different Islamic school for my study. Seidman (2013) warned researchers about too much familiarity between participants and researchers:

Instead of exploring assumptions and seeking clarity about events and experiences, they tend to assume that they know what is being said. The interviewer and the participant need to have enough distance from each other that they take nothing for granted. (p.46)

The school where I ultimately conducted my study was largely unfamiliar to me. However, I knew one of the teachers at the school, and she became my first point of contact for the data collection. She spoke with the principal about my study and provided the principal with my contact information. The principal contacted me shortly thereafter, and with her help, I completed my study with participants from her school. I also knew one of the parent participants in the study, although I was unaware that I knew her until I recognized her at the time of the interview.

With the exception of the one teacher whom I had known previously and the parent that I recognized at the interview, all other participants were unfamiliar to me. On one hand, I was able to explore assumptions with these participants in ways that may have been impossible with participants with whom I was acquainted. On the other hand, the formality between us may have hindered the level of social intimacy required to conduct truly in-depth interviews. 


\section{Diversity of Respondents}

Although the diverse sample of respondents who varied in terms of experience, gender, education, and cultural background allowed for a variety of voices to be included in the study, the participants' linguistic diversity may have affected the results of the study. For example, parents whose first language was Arabic were more inclined to expect a rigorous Arabic curriculum for their children. However, parents who did not speak Arabic at home tended to expect an Arabic curriculum that included English translations. This variance in language use may have influenced the results of the study.

\section{Bias of Researcher}

Although I was unfamiliar with most of the participants, which may have limited the degree of bias, I was a teacher and parent at the time of the study, which may have increased the degree bias. For example, when I asked parents about their experiences with Islamic schools, as a parent myself, I interpreted their answers through my own parent lens. Likewise, when I asked teachers about their experience working in Islamic schools, as a teacher, I interpreted their answers through my own teacher lens. For instance, one of the teacher respondents grew up in a Catholic family and attended Catholic school before she converted to Islam. Perhaps I unconsciously paid closer attention to her interview since both of us shared a similar upbringing. Even though I was unfamiliar with most of the participants, I did have comparable experiences with them as a teachers and parent affiliated with an Islamic school, which could have affected the results of the study. 
STAKEHOLDER EXPECATIONS OF ISLAMIC EDUCATION

\section{Chapter 5: Discussion and Conclusion}

In the preceding chapters, I explained that teachers and parents have made considerable sacrifices to affiliate themselves with Islamic schools. As they committed to Islamic education, they have acquired certain expectations that they want their school to fulfill. The purpose of this study was to explore the expectations of teachers and parents in an Islamic School on the West Coast (WCIS) in order understand how these expectations could be fulfilled in other Islamic schools across the United States. In order to understand these expectations, I proposed a study with two research questions in mind:

1.What are the academic, social, and cultural expectations that parents and teachers have of their Islamic schools?

2. To what extent are Islamic schools meeting the expectations of parents and teachers?

When parents and teachers affiliate themselves with Islamic schools, they have certain cultural, academic, and social expectations for children. To frame what these expectations are and how parents and teachers acquire these expectations, I used social constructivism which is a theory of knowledge that highlights the interdependent nature of human understanding whereby individuals collaborate to construct meaning.

To examine the expectations of teachers and parents, I used a qualitative (Maxwell, 2013), phenomenological approach (Creswell, 2013) in which I surveyed parents and teachers at WCIS using preliminary and follow-up questionnaires. Then I conducted 90-minute, in-depth interviews with teachers and parents. The backgrounds of 
the participants varied in order to incorporate a diversity of voices in the study. I gathered data from preliminary questionnaires, follow-up questionnaires and in-depth interviews to answer my research questions.

\section{Synthesis of Findings}

For the first research question (What are the academic, social, and cultural expectations that parents and teachers have of their Islamic schools?), I found that teacher and parent participants in the study expected children to be knowledgeable about Islam. Knowledge of Islam included understanding the basics such as the five pillars of Islam and the six pillars of faith. Several participants believed that children should learn about Islam by reading, writing, and speaking about Islam in its original language of Arabic. Other participants felt that children should learn about Islam in their primary language in order to increase their understanding of Islam. Many participants expected children to acquire a balanced education that included Islamic studies as well as general education classes. Although some participants differed in their approach toward Islamic education, they all agreed on their expectation for children to be knowledgeable about Islam.

In addition to expecting children to be knowledgeable about Islam, I found that participants expected children to apply their knowledge of Islam in practical ways that benefitted others. For example, students were expected to read and understand the Qur'an in Arabic and be able to apply the contents of the Qur'an for the benefit of others, such as

demonstrating kindness and generosity. Students were also expected to be knowledgeable about Islamic virtues, and then use this knowledge to contribute to society through acts of 
good will toward others, such as participating in acts of charity and social justice causes. Additionally, students were expected to learn about Islamic character, develop it within themselves, and then interact respectfully and compassionately with others. Furthermore, students were expected to demonstrate respect toward the school community, especially toward parents, teachers, and older members of the community. Students were also expected to dress modestly, observe prayers in a timely basis, and use language in a way that exhibited Islamic manners. Examples include the Islamic greeting As Salaamu alaikum (peace be upon you) when addressing others, alhamdulillah (praise be to God), insha Allah (God willing) and JazakAllahu khair, (thank you and may God reward you) and Masha Allah (to express appreciation and joy). Also, students were expected to practice their Islamic faith by loving God and all of His creation, including people of different faiths and backgrounds, strangers, neighbors, the environment, animals, and all creatures. Regarding drugs, alcohol, violence, premarital sex and other potentially dangerous behavior, students were expected to apply the lessons they learned in school by abstaining from practices that could harm others and themselves. In general, students were expected to face the inevitable challenges of the outside world by balancing their Islamic values with the demands of a dynamic and competitive society. Ultimately, students were expected to actively participate and contribute to the general community in positive ways that aligned with their Islamic faith.

For the second research question (To what extent are Islamic schools meeting the expectations of parents and teachers?), I found that the degree to which Islamic schools were meeting the expectations of parents and teachers depended on the level of support 
within the school community. Several examples of community support emerged from the data including teachers who offered children extra emotional support during difficult transitions in their lives. Teachers in the study supported incoming students as they adjusted to their new school by incorporating Islamic manners such as inclusiveness and compassion. Several teacher participants supported children in general by creating a safe and happy learning environment for them. Many teachers collaborated with each other to support struggling students by spending extra time, energy and resources on students that needed additional assistance. School leaders, such as the principal and veteran teachers went out of their way to support and strengthen their math and science programs, resulting in multiple awards at local science fair competitions. Parents also played critical roles by supporting their children's Islamic education in spite of their own financial, religious, or academic limitations. Teachers supported a school environment where boys and girls learned to behave respectfully toward one another through courteous language and actions. Additionally, staff supported the diversity of its Muslim community by welcoming students and parents from various ethnic backgrounds. Teachers also supported students in developing a strong Muslim identity by instilling a sense of pride in their rich Islamic heritage. Additionally, teachers supported parents who were struggling to fill some of the gaps in their children's Islamic education, such as children of converts who were new to the teachings of Islam. Finally, teachers supported parents who wanted their children to apply their Islamic knowledge in a real world context, such as participating in extracurricular activities such as sports, arts and community service. 
The degree in which Islamic schools were falling short of meeting the expectations of parents and teachers depended on the level of support within the school community. Examples that illustrated the school community's lack of support that emerged from the data included some teachers who felt unsupported by parents who did not provide Arabic language support to their children who struggled in Arabic class. Moreover, some Arabic teachers felt unsupported in being trained on the best ways to teach Arabic. Additionally, there were parents who felt unsupported in their effort to ensure their children learned Arabic sufficiently in a half- English/half-Arabic class. Also, some teachers felt unsupported by parents who failed to show up for conferences, volunteering, and other school gatherings.

Likewise, there were parents who felt a lack of support from teachers who failed to use modern teaching techniques and up-to-date technology in the classroom. Some teachers felt unsupported by students who practiced exclusionary behavior with classmates from different backgrounds. Some teachers also felt unsupported by a few colleagues, parents and students for showing a lack of respect toward one another. Some teachers felt unsupported by parents who failed to reinforce Islamic behavior at home, such as establishing regular prayer time and reinforcing Islamic manners and modesty. Finally, some school leaders felt a lack of support from major stakeholders when it came to creating a vision for school growth, such as planning and fundraising for school expansion. 
STAKEHOLDER EXPECATIONS OF ISLAMIC EDUCATION

\section{Social Constructivism Situated in Larger Context}

My findings aligned with a framework based on social constructivism which is a theory of knowledge that highlights the interdependent nature of human understanding whereby individuals collaborate to construct meaning. In my study, the school community worked together to create meaningful educational experiences for students that nurtured their Islamic faith. In the process, teachers and parents acquired certain expectations that they wanted their Islamic school to fulfill. My findings revealed that teachers and parents expected children to acquire knowledge of Islam. Furthermore, teachers and parents expected children to apply their knowledge of Islam in their everyday lives. The degree to which these expectations were fulfilled depended on the support that teachers and parents received from the school community. Teachers and parents acquired these expectations using the social, cultural and historic components of social constructivism.

Examining expectations through the lens of social constructivism allowed for critical input from teachers and parents who depended upon each other to co- create meaningful educational experiences for the children they nurtured at school and home. Moreover, social constructivism enabled stakeholders to express different ways of understanding Islamic education and to interpret what Islamic education meant to them. Finally, social constructivism permitted teachers and parents to trace back the historical, cultural and social origins of Islamic education that influenced their expectations. 
Using social constructivism as a theoretical framework clarified how my findings originated and evolved from historical, cultural and social contexts. For example, my findings regarding the expectation of children being knowledgeable about Islam related to the origin of Islam itself. As described in the Islamic tradition, God revealed the Qur'an to Prophet Muhammad through Archangel Gabriel whose first words were, "Read." Over the next twenty- three years of revelation, Prophet Muhammad recited verses to his closest companions who, in turn, wrote them down in what became the Qur'an. The interaction between God, Archangel Gabriel, Prophet Muhammad, and his companions who wrote down the revelations is an example of the way social constructivism provided a framework for the study. The expectation that teachers and parents expressed for children to be knowledgeable about Islam originated from the sacred collaboration between God, Archangel Gabriel, Prophet Muhammad, and his companions who co-constructed the Holy Qur'an and the advent of Islam. When teachers and parents expected children to be knowledgeable about Islam, they expected children to understand the origins of Islam — the divine inspiration, the major players and the sequence of events that resulted in the creation of Islam. Social constructivism framed the findings that related to the expectation to be knowledgeable about Islam by connecting children to the interdependent and collaborative sources of their Islamic faith.

Social constructivism also related to the finding that teachers and parents expected children to apply their knowledge of Islam in their everyday lives. The application of Islamic knowledge corresponded to the contents of the Qur'an as well as Haddith, which are a collection of the practices and sayings of Prophet Muhammad that 
were narrated and written down by his closest companions. Muslims believe that Prophet Muhammad embodied the best qualities of a human being, therefore teachers and parents in the study expected children to apply their knowledge of Islam in ways that exemplified the words, behavior and actions of Prophet Muhammad. The example set by Prophet Muhammad, the subsequent narration and written form of the Haddith, and the expectation for children to imitate Prophet Muhammad's words and deeds illustrate the collaborative nature of social constructivism whereby knowledge is socially and culturally constructed.

Finally, social constructivism also corresponded to the findings in the study related to the expectations of teachers and parents that were met depending on the degree of support from the school community. The school community was part of the wider Islamic community, or Ummah, that was united by their common Islamic faith. Teachers and parents whose expectations were met felt supported by their Ummah. Social constructivism manifested itself as the teachers, parents and the school community, the Ummah, collaborated to create a meaningful educational experience for the children at WCIS.

An example of social co-construction occurred when teacher and parent participants met to discuss the disconnection that some children experienced in their Islamic studies classes that were taught exclusively in Arabic. The school community coconstructed a new Islamic studies curriculum that included English along with Arabic lessons, resulting in students who attained a better understanding of their faith. 
STAKEHOLDER EXPECATIONS OF ISLAMIC EDUCATION

\section{Expectations to be Knowledgeable}

In addition to findings that aligned with a framework based on social constructivism, my findings also related to the literature on expectations to be knowledgeable about Islam. For example, when Khadija, a teacher participant, explained, We want to make sure we provided quality education but at the same time to make sure that we raised them as Muslims and teach them about the religion" she was echoing the holistic approach to education that Douglass and Shaikh (2004) described: "Muslim schools carrying out education for Muslims strive to achieve educational excellence, but also to integrate religious values into instruction across the curriculum and through service-learning in the family, the school and the community" (p.9). Likewise, Aminah expressed the same desire for her children to experience a holistic education when she mentioned that she had "seen a lot of kids that had either the education that was strong in [general] education but not in their religion or Islam, or the other way with no education, and so she wanted her kids to have a balance." Khadija and Aminah, along with Douglas and Shaikh (2004), emphasized the importance of providing an opportunity for children to gain knowledge about Islam that balanced academic rigor with practical religious teachings.

Another example that illustrated how the literature review corresponded to the study involved Fatima and Aminah, two parents who uprooted and moved a considerable distance to live near an Islamic school for their children to attend. Fatima explained, "I actually moved here so I could put my children into Islamic school. We felt that it was important that he be surrounded with a good foundation in Islam.” Similarly, Aminah, 
through a translator, described her journey to live next to an Islamic school: "My mom always wanted to bring her kids to somewhere where they can learn their religion, so one of her friends used to live here and told her about the school which is why we moved all the way across the country for it." Fatima and Aminah's willingness to travel great lengths to send their children to an Islamic school reiterated a Haddith that Prophet Muhammad was reported to have said: "Whoever takes a path upon which to obtain knowledge, Allah makes the path to Paradise easy for him." (At-Tirmidhi, 2007, pp. 5051). In a similar Haddith, the Prophet was reported to have said, "Whoever travels a road seeking knowledge thereby, Allah will cause him to travel one of the roads to Paradise. The angels lower their wings in approval of the seeker of knowledge" (Abu-Dawud, 2008, p. 207). These Haddith correspond with Fatima and Aminah's commitment to provide a sound Islamic education for their children, even if that meant pulling up stakes and traveling long distances to find a solid Islamic school for their children.

\section{Expectations to Apply Knowledge of Islam}

In addition to findings related to the literature on expectations to be knowledgeable about Islam, my findings also corresponded to the literature on expectations for students to put their knowledge of Islam into practice. For example, Zaynab's point about Islam being a religion of peace and love illustrated Shah's (2016) position about the responsibility toward others that Islamic schools emphasized. When Zaynab urged students to "do your religion, practice, love Allah, love your Prophet, love your neighbor, love your friend, your family," she was reaffirming Shah's (2016) statement about the social obligation to care for others: "The social dimension of 
education underlining individuals' responsibility toward others is reflected in an emphasis on obligations to other human beings, which is aimed at collective good" (p. 3). Both Zaynab and Shah (2016) emphasized the importance of applying Islamic principles by caring for others.

Another example of findings that related to the literature on expectations for students to put their knowledge of Islam into practice included Abdul Rashid's experience as a son and later, as a father. As a son, his parents made sacrifices so he could earn a degree and find his purpose in life: "My parents were hard working and made sure all of their ten children have university degrees. My religion makes it mandatory to strive for your best potential as Allah's representative on this earth." As a father, Abdul Rashid expected his own children to apply their knowledge of Islam by contributing to society in meaningful and kindhearted ways: "To teach my children how to be respectful and grateful, productive citizens of society, to treat and instill in them kindness, mercy and compassion.” Abdul Rashid's expectations for his children to put their academic achievement to work in the community related to the literature of Douglass and Shaikh (2004) who argued, "Muslim schools carrying out education for Muslims strive to achieve educational excellence, but also to integrate religious values into instruction across the curriculum and through service-learning in the family, the school and the community" (p. 9). Both Douglass and Shaikh (2004) as well as Abdul Rashid emphasized the importance of excelling in school, then taking the next step of using their acquired knowledge to improve society. 


\section{Met and Unmet Expectations}

In addition to findings that corresponded to the literature on expectations for students to put their knowledge of Islam into practice, my findings were also consistent with the literature on the extent to which expectations were met depending on the level of support from the school community. For example, Fatima expressed how her expectations were met due to the compassionate learning environment at school. She explained, "The teachers care, they're empathetic, they want the kids to succeed, and if they feel like something's going on, they'll question it, they'll send me a note, they'll call me, say what's going on." Fatima's experience with caring teachers who reached out to parents when their child needed guidance corresponded with Memon's (2011) study that addressed discipline in Islamic schools. Memon's (2011) stated, “a number of Islamic school teachers mentioned the need to embody examples of his [Prophet Muhammad] wisdom (hikma) when wanting to motivate and inspire students. This includes addressing misbehavior or correcting inappropriate actions with mercy (rahma)" (p. 292). Another teacher in Memon's (2011) study emphasized the influence of Prophet Muhammad's example of benevolence in the classroom when she mentioned, "having a nice combination of teaching strategies plus our Prophet's way of being kind and caring (peace and blessing upon him), that is most important" (p. 291). The teachers in Memon's (2011) study, along with parents like Fatima, tried to emulate the exemplary qualities of compassion and respect that Prophet Muhammad demonstrated to those around him. 
Another example of a finding that was consistent with the literature on the extent to which expectations were met involved Mariam, whose expectations were fulfilled due to the supportive cultural environment of her diverse classroom. Mariam explained,

When we see different people and live with them and when you get to know other people from other culture, then you start to know those people, not just whatever you hear on the TV about how, the bad things about them, but you have to really appreciate people, who they are.

Mariam's diverse and inclusive classroom culture related to Shah's (2016) explanation of the purpose of Islamic education: "Education in Islam should aim to prepare human beings for leading a life of 'righteousness' in a social context. The perceptions contribute to enhanced expectations of Muslim learners and communities of education in diverse contexts" (p. 24). Mariam and other teachers in the study, along with Shah (2016), emphasized the connection between inclusion in diverse learning environments and living virtuously. When students from various backgrounds got to know each other and appreciate their differences, they were learning to apply a well-known verse from the Qur'an: "We have created you from male and female and made you peoples and tribes that you may know one another. Indeed, the most noble of you in the sight of Allah is the most righteous of you" (Qur'an 49:13).

On the other hand, an example of a finding that was consistent with the literature regarding the extent to which expectations were not met involved Zaynab, whose expectations were unfulfilled due to a lack of support in her school community. Zaynab 
and other teachers mentioned an absence of parental support during conferences, volunteering, meetings, and gatherings. Zaynab appealed to parents, "This is your child. This is your life, and I wish to see the parents more, to communicate more, to understand what's going on in their lives. That will help their children too." Similarly, Merry (2007) stressed the critical part that parents played in helping to create an optimal environment for children. "A learning environment culturally (or religiously) consonant with parents is more likely to produce healthy learning outcomes for young children and is more likely to foster a firmer sense of self' (p. 78). The success of the learning environment at WCIS was dependent on the involvement of parents, and when some parents failed to meet the social expectations of teachers, students were the ones who suffered the consequences.

Another example of a finding that was consistent with the literature regarding the extent to which expectations were not met involved Ruqayah, a parent whose expectations were unfulfilled due to a lack of support in her school community. Ruqayah mentioned that her daughter was bored in school due to the traditional lecture style of learning:

She's learning the same style I used to learn when I was in my country, and she sees her siblings when she comes home because the other ones, they go to public school, and they talk, and she knows now the difference.

Ruqayah expected her daughter to receive an education that was better than that of her country of origin. Moreover, Ruqayah expected her daughter to receive an education that was at least as good as that of a public school. However, on both accounts, Ruqaya felt 
that her daughter's Islamic school experience was failing to meet some of her academic expectations. Ruqaya's concern was addressed in Merry's (2005) study that emphasized parent's demand for a high quality education for their children that included a rigorous academic curriculum along with religious studies: "Muslim parents are seeking to secure for their children the highest academic formation that they can afford" (p. 378). Similarly, Haddad et al. (2009) stressed the value that parents placed on a first rate education for their children: "They are extremely eager that their children receive the best education possible and want to make sure that Muslim schools have high educational standards" ( $\mathrm{p}$. 11). Throughout the study, the commitment to high academic achievement of teachers and parents, in addition to balanced religious instruction, was reflected in the literature.

\section{Implications}

To summarize, teachers and parents in the study expected children to be knowledgeable about Islam. Additionally, teachers and parents expected children to apply their knowledge of Islam to their lives. The degree to which these expectations were met depended on the support that teachers and parents received from the school community. With the questions of the study addressed and the findings related to the research literature and theoretical framework summarized, I will conclude by making recommendations for Islamic schools that are currently in operation in the United States.

Although the study centered on the expectations of teachers and parents, children played an equally integral role since, without the presence of children, the study could not exist. Regarding the first research question about teachers and parents expecting children 
to be knowledgeable about Islam, it was important to consider the role that children played in these expectations. Similarly, the research question about teachers and parents expecting children to apply knowledge about Islam in their lives also depended upon the involvement of children in the study. As Engeström (1987) illustrated in his CulturalHistorical Activity Theory, each component in the human activity system, including children, worked together to socially construct a meaningful educational experience. Since children were the recipient of expectations in the study, it is essential to consider children when making recommendations for future practices of Islamic schools.

Teachers and parents expressed their expectations for children in the study, but in order for children to meet and act on these expectations, the Islamic school had certain responsibilities toward the children they served. Teachers and parents expected children to be knowledgeable about Islam and to apply this knowledge in their lives, but their knowledge and application should be worthy of the time and effort that children spent learning and applying it. The Islamic knowledge that children were expected to learn and apply should aspire toward the highest ideals of Islamic education such as some of the main Islamic principles that Shah (2016) discussed including ta'lim (to know), tarbiyah (to increase and grow), $t a^{\prime} d i b$ (the disciplining of the mind, body, and soul), shura (consultation), ijtihad (rational consensus) and ikhtilaf (disagreement, diversity, pluralism).

The Islamic school in the study fell short of some of the principles that Shah (2016) mentioned, such as tarbiyah (to increase and grow) in the case of Ruqayah, a 
parent participant who complained because her daughter was "getting bored because she's learning the same style I used to learn when I was in my country." Ruqayah expected her daughter to increase her understanding as a student and grow as a person. Instead, her creativity, especially in the area of artistic expression, was stifled due to a school curriculum lacking in the arts. Another area where the Islamic school did not meet the expectation of a participant related to the principle of Ikhtilaf (disagreement, diversity, pluralism). Aisha, a teacher participant, explained, "From the students, as you can see, from different cultures, from different countries, some of them, they don't get together, like they fight, they argue together, they say bad words." Aisha expected her students, who were from various backgrounds, to get along because they shared an Islamic identity. However, her students' common Islamic faith was not enough to overcome their differences. Ramadan (2009) addressed Ruqayah's and Aisha's concern for the lack of creative expression as well as inclusiveness toward others when he argued,

Respect for diversity, human solidarity, and cultural and artistic creativity should also be taught; such are the schools we need today, and they should combine traditional methods with more innovative approaches in order to take up the challenges of contemporary times. (p. 280)

Traditional teaching methods need not be eliminated, but these methods should be balanced with innovative practices that reflect the modern world that students must learn to navigate. 
Some of the short-fallings of WCIS were reflected in the critique of Islamic schools that Ramadan (2009) highlighted. Ramadan (2009) criticized Islamic schools for excluding many of the principles that Shah (2016) described as epitomizing Islamic education such as emphasizing growth and knowledge, disciplining of the mind, body, and soul, fostering diversity and pluralism, and allowing for disagreement within the school community. Regarding Islamic schools in general, Ramadan (2009) argued, "Islamic' subjects are added, but those schools rarely excel for their philosophy of education, their original teaching methods, and their concern for practical consistency with the higher principles of ethics" (p. 280). Zaynab, a teacher participant in the study, confirmed the need to improve the way that Islamic subjects, such as Arabic, are taught. She recommended, "Have new ways of teaching this language, it will help. New methods maybe, experiences." Zaynab recommended using shura (consultation), one of the principles of Islamic education that Shah (2016) described, as a way of developing and enhancing the way Arabic language is taught in Islamic schools. Zaynab explained, "It's like many many schools do it together and work on it." Teaching Islamic subjects, such as Qur'anic studies, Islamic history, and Arabic language in an Islamic school, does not automatically guarantee a deeper understanding of Islam or the ability for students to apply knowledge of Islam in a meaningful way. Zaynab maintained, "It's a hard language, not that easy, so they need like really good professionals to do that job." A sacred and complex language such as Arabic needs to be taught using methods that students can relate to on a spiritual and intellectual level. 
STAKEHOLDER EXPECATIONS OF ISLAMIC EDUCATION

Ramadan (2009) contended that Islamic schools should aim to provide a transformative education that reaches into the depths of the minds and souls of students and compels them to act for the good of humanity. Ramadan (2009) challenges Islamic schools to

impart knowledge and awaken pupils' consciences, shape their critical minds, lead them toward autonomy, and awaken them to personal and collective responsibility. A society that is intellectually, culturally, and politically open, that experiences true qualitative and human development, needs a school system and schools that promote such values and ethical principles. (p. 280)

Without a higher level of learning that raises students' consciences, promotes critical thinking, and encourages autonomy in and out of the classroom, Ramadan (2009) warned that students will become mere commodities in an increasingly materialistic society. Ramadan cautioned Islamic schools not to "end up yielding to the dictates of economy by being privatized or becoming obsessed with the specific, standardized production of 'gray matter' just as some firms focus on producing raw materials" (p. 280). Fatima, a parent participant in the study, illustrated Ramadan's (2009) point by equating success in life with her son's academic achievement:

I think that in general, in life, you need an education to get the good jobs. I've been showing him right now his grades from junior high starting now. So trying to show him that his academic achievements at this stage in his life will make a 
difference in the rest of his life and trying to instill that into him so that he has a chance for success in this world.

Rather than emphasizing the material gains of academic achievement, Ramadan (2009) espouses a highly moral and ethical Islamic education for children using innovative teaching methods that are rooted in a desire to help students navigate the complexities of our rapidly evolving world.

To conclude, for Islamic education to be relevant for Muslim children, teachers and parents must go beyond what is expected. Teachers and parents must expect more out of children than being knowledgeable about Islam and applying their knowledge of Islam. Islamic schools run the risk of insulating students in a protective Islamic environment while isolating them from the influences of the wider society in the process. In his critique of Islamic schools in general, Ramadan (2009) argued, "what motivates those projects is often fear and the desire to protect children from globalized culture or behaviors little involved with ethics. This defensive approach is everywhere showing its limits and often its counterproductive character" (p. 280). Mariam, a parent participant in the study, illustrated a desire for some parents to enroll their children in Islamic school to surround them with like-minded people rather than to expose children to diverse populations and multifaceted perspectives: "As a convert, and my husband also is a convert, so sending our children to an Islamic school is kind of a place where our children can be around a lot of Muslims." In the short run, this mind set can be reassuring to parents who want to protect their children from outside influences that challenge their 
beliefs. In the long run, however, parents run the risk of doing a disservice to these children who, instead of isolating themselves, need to engage in society as strong and equal participants who are contributing their time and energy for the benefit of the wider community.

Although the Islamic school community has much to gain by understanding what teachers and parents expect from Islamic schools, the future of Islamic education depends on a school community that positions itself in the more expansive arena of the public square. Khadija, a teacher participant in the study, illustrated this point on a smaller scale when she asked stakeholders at the Islamic school, "Are we going to stay where we are right now? Or do we have a vision to help it grow?" In a world that is increasingly troubled by political, social, economic, and environmental challenges, it is critical for Muslim students to create and implement a vision to help the citizens of the world to grow stronger and kinder. Students in Islamic schools need to take their knowledge of Islam out of the classroom and onto the world stage where they can apply their knowledge toward changing public policy, leading social movements, and becoming agents who help create a more just, equal, and caring society. 
STAKEHOLDER EXPECATIONS OF ISLAMIC EDUCATION

References

Abuarqub, M. (2009). Islamic perspectives on education. Retrieved from www.islamicrelief.com/indepth/downloads/Islamic\%20perspectives\%20on\%20education \%20Feb09.pdf

Abu-Dawud, S. (2008). English translation of Sunan Abu-Dawud. Riyad, Saudi Arabia: Darussalam.

Akhtar, S. W. (1997). The Islamic concept of knowledge. Al-Tawid, A Quarterly Journal of Islamic Thought \& Culture, 12(3), 2.

Al-Taftazani, A. W. (1986). Islamic education: Its principles and aims. Muslim Education, 4(1), 67.

Al-Attas, M. (1979). Aims and objectives of Islamic education. Jeddah, Saudi Arabia: Hodder and Stoughton.

Al-Attas, M. (1977). The concept of education in Islam. Retrieved from www.mefca.org/files/attas-text-final.pdf

Alexakos, K., \& Antoine, W. (2005). The golden age of Islam and science teaching. Science Teacher, 72(3), 37-39.

Al-Ghazali, M. (1962). The book of knowledge. (N. A. Faris, Trans.). New Delhi, India: Islamic Book Service. 
Al-Hajj, M. (2009). Mokthtaser sahih Muslim. Retrieved from http://archive.org/details/SahihMuslim- IslamicEnglishBook.pdf

Ali, A. Y. (1994). The meaning of the Holy Qur'an. Brentwook, MD: Amana Corporation.

Armstrong, K. (2006). Muhammad: A prophet for our time. New York, NY: HarperCollins.

At-Tirmidhi, M. E. (1983). Hadith al-Tirmidhi. Retrieved from http://www.alim.org/library/hadith/TIR/10 7

At-Tirmidhi, M. E. (2007). English translation of Jami At-Tirmidhi. (T. Z. Ali Zai Ed.). (A. Khaliyl, Trans.). Riyad, Saudi Arabia: Darussalam.

Blackwell-Flanagan, R. (2012). Toward a more perfect union. In C. Gerstl-Pepin \& J. A. Aiken (Eds.), Social justice leadership for a global world (p. 312). Charlotte, NC: Information Age Publishing.

Blanchard, C. M. (2007). Islamic religious schools, madrasas: Background. CRS Report for Congress. Washington, DC: Library of Congress.

Bogdan, R.C., \& Biklen, S. K. (2007). Qualitative research for education: An introduction to theory and methods ( $5^{\text {th }}$ ed.). Boston, MA: Allyn \& Bacon.

Bradley, W., \& Schaefer, K. (1998). The uses and misuses of data and models. Thousand Oaks, CA: Sage. 
STAKEHOLDER EXPECATIONS OF ISLAMIC EDUCATION

Bruner, J. S. (1978). The role of dialogue in language acquisition. In A. Sinclair, R., J. Jarvelle \& W. J.M. Levelt (Eds.), The Child's Concept of Language (pp. 241256). New York, NY: Springer-Verlag.

Bruner, J. S. (1996). The culture of education. Cambridge, MA: Harvard University Press.

Charmaz, K. (2006). Constructing grounded theory: A practical guide through qualitative analysis. Thousand Oakes, CA: Sage.

Cheddadi, A. (2000). Ibn Khaldun. Paris, France. UNESCO International Bureau of Education. Crabtree, B. F., \& Miller, W. L. (Eds.). (1999b). Doing qualitative research $\left(2^{\text {nd }}\right.$ ed.). Thousand Oaks, CA: Sage.

Creswell, J. W. (2013). Qualitative inquiry \& research design. Thousand Oaks, CA: SAGE Publications.

Crotty, M. (1998). The foundations of social research: Meaning and perspective in the research process. Crows Nest, Australia: Allen \& Unwin.

Dewey, J. (1938). Experience and education: The $60^{\text {th }}$ anniversary edition. Indianapolis, IN: Kappa Delta Pi.

Douglass, S. L., \& Shaikh, M.A. (2004). Defining Islamic education: Differentiation and application. Current Issues in Comparative Education, 7(1), 5-18.

Elbih, R. (2012). Debates in the literature on Islamic schools. Educational Studies, 48, 

156-173.

Engeström, Y. (1987). Learning by expanding: An activity-theoretical approach to developmental research. Helsinki: Orienta-Konsultit.

Engeström, Y. (1993). Developmental studies of work as a testbench of activity theory: The case of primary care medical practice. Understanding Practice: Perspectives on Activity and Context, 64-103. Retrieved from http://scholar.google.com/citations? user $=g Z W y K a k A A A A J \& h l=e n$

Engeström, Y. (2001). Expansive learning at work: Toward an activity theoretical reconceptualization. Journal of Education and Work, (14)1, 133-156.

Ernest, P. (1999). Social constructivism as a philosophy of mathematics. Albany, NY: State University of New York Press.

Esposito, J. L. (Ed.). (1999). The Oxford history of Islam. New York, NY: Oxford University Press.

Expectation. (2015). In Oxford English Dictionary online. Retrieved from http://www.oed.com/view/Entry/66455?redirectedFrom=expectation

Gredler, M. E. (1997). Learning and instruction: Theory into practice (3rd ed). Upper Saddle River, NJ: Prentice-Hall.

Guba, E.G., \& Lincoln, Y.S. (2007). Paradigmatic controversies, contradictions, and emerging confluences. In N. K. Denzin, \& Y. Lincoln (Eds), The landscape of 
STAKEHOLDER EXPECATIONS OF ISLAMIC EDUCATION

qualitative research (3rd. ed.) (pp. 191-215).Thousand Oaks, CA: SAGE

Publications.

Haddad, Y.Y., Senzai, F., \& Smith, J. (2009). Educating the Muslims of America. New York, NY: Oxford University Press.

Halstead, J. M. (2004). An Islamic concept of education. Comparative Education, 40(4), 517- 529.

Hilgendorf, E. (2003). Islamic education: History and tendency. Peabody Journal of Education, 78(2), 63-75.

Hussain, S., \& Ashraf, A. (1979). Crisis in Muslim education. Jeddah, Saudi Arabia: Hodder and Stoughton.

Iqbal, Z. (1996). Teachers' training: The Islamic perspective. Islamabad, Pakistan: The Institute of Policy Studies, Islamabad and International Institute of Islamic Thought.

Khan, M. (1997). The translation of meanings of Sahih Al-Bukhari. (M. M. Khan Trans.) Riyadh, Saudi Arabia: Darussalam.

Krathwohl, D.R. (2009). Methods of educational and social science research. Long Grove, IL: Waveland Press.

Kukla, A. (2000). Social constructivism and the philosophy of science.

New York, NY: Routledge. 
Lightfoot, S. L. (1983). The good high school: Portraits of character and culture. New York, NY: Basic Books.

Maxwell, J. A. (2013). Qualitative research design: An interactive approach.

Thousand Oaks, CA: SAGE Publications.

McMahon, M. (Dec. 1997). Social constructivism and the World Wide Web - A paradigm for learning. Paper presented at the Australasian Society for Computers in Learning in Tertiary Education conference. Perth, Australia.

Memon, N. (2011). What Islamic school teachers want: Toward developing an Islamic teacher education program. British Journal of Religious Education, 33, 285- 298.

Merry, M. S. (2005). Advocacy and involvement: The role of parents in Western Islamic schools. Religion Education: The Official Journal of the Religious Education Association, 100(4), 374-385.

Merry, M. S. (2007). Culture, identity, and Islamic schooling: A philosophical approach. Basingstoke, UK: Palgrave Macmillan.

Niyozov, S., \& Pluim, G. (2009). Teachers' perspectives on the education of Muslim students: A missing voice in Muslim education research. Curriculum Inquiry, 39(5), 637-677.

Prawat, R. S., \& Floden, R. E. (1994). Philosophical perspectives on constructivist views of learning. Educational Psychologist, 29(1), 37- 48. 
Ramadan, T. (2004). Western Muslims and the future of Islam. New York, NY: Oxford University Press.

Renaerts, M. (1999). Processes of homogenization in the Muslim educational world in Brussels. International Journal of Educational Research, 31, 283-294.

Rusd, I. (1960). On the harmony of religions and philosophy (G.F. Hourani, Trans.). London, England: Luzac.

Saldaña, J. (2009). The coding manual for qualitative researchers. Thousand Oaks, CA: SAGE Publications.

Seidman, I. (2013). Interviewing as qualitative research: A guide for researchers in education \& the social sciences. New York, NY: Teachers College Press.

Shah, S. (2016). Education, leadership and Islam: Theories, discourses and practices from an Islamic perspective. New York, NY: Routledge.

Sina, I. (1984). Remarks and admonitions. Part one: Logic (S. C. Inati, Trans.). Wetteren, Belgium: Universa Press.

Sirin, S., \& Fine, M. (2008). Muslim American youth: Understanding hyphenated identities through multiple methods: New York: New York University Press.

Strauss, A. L. (1987). Qualitative analysis for social scientists. Cambridge, England: Cambridge University Press. 
Tauhidi, D. (2001). The tarbiyah project: Towards a renewed vision of Islamic education. Retrieved from www.bcmaburnaby.org/.../Tarbiyah\%200verview\%20\%20Dawud\%20Tauhidi.pdf

Vogt, W.P., Gardner, D.C., \& Haeffele, L.M. (2012). When to use what research design. New York, NY: Guilford Press.

Vygotsky, L. S. (1978). Mind in society: The development of higher psychological processes. Cambridge, MA: Harvard University Press.

Zarnuji, I. B. (2003). Instruction of the student: The method of learning (G.E. Von Grunebaum \& T. Abel, Trans.). Chicago, IL. Starlatch Press. 


\title{
Appendix A
}

\author{
Preliminary Questionnaire
}

1. What is your gender?
a. Male
b. Female

2. What is your ethnic background?
a. Middle Eastern
b. Southeast Asian
c. African
d. White
e. Other

3. What is the main role(s) you have in your Islamic school?
a. Parent
b. Teacher
c. Both

4. How long have you been involved in this role(s)?
a. Less than one year
b. Between one and three years
c. Between three and five years
d. Six or more years

5. If you have children, how many attend(ed) Islamic school?
a. 0
b. $1-2$
c. $3-4$
d. 5 or more

6. If your children attend(ed) Islamic school, how many years have they been enrolled?
a.1-2 years
b. $3-4$ years
c.5-6 years
d. 7 or more years 


\section{Appendix B}

\section{Questionnaire Follow-up}

1. As a teacher and/or parent, how satisfied are you with the quality of education at your Islamic school?
a. Extremely satisfied
b. Satisfied
c. Somewhat satisfied
d. Not satisfied at all

2. As a teacher and/or parent, what are your primary expectations for Islamic education?
a. Academic
b. Cultural
c. Religious
d. Social
e. A combination of

3. As a teacher and/or parent, are your expectations largely being met by your Islamic school?
a. Definitely, yes.
b. Yes, but there's some room for improvement.
c. Somewhat.
d. Not really.

4. If you answered that your expectations are largely being met, please describe how your Islamic school is meeting your expectations as teacher and/or parent. If you answered that your expectations are generally not being met, please describe how your Islamic school is not meeting your expectations as teacher and/or parent. 


\section{Appendix C}

\section{Interview Questions}

1. If you are a teacher at an Islamic school, what is your experience with Islamic education? What made you interested in teaching at an Islamic school?

2. If you are a parent at an Islamic school, what is your experience with Islamic education? What made you interested in sending your child to an Islamic school?

3. What academic expectations do you have of your Islamic school?

4. Why do you have these academic expectations? Describe how your background, values, faith, culture, and anything else you would like to add, influence your expectations.

5. Are your academic expectations being met? If yes, how? If not, why not?

6. What social expectations do you have of your Islamic school?

7. Why do you have these social expectations? Describe how your background, values, faith, culture, and anything else you would like to add, influence your expectations.

8. Are your social expectations being met? If yes, how? If not, why not?

9. What cultural expectations do you have of your Islamic school?

10. Why do you have these cultural expectations? Describe how your background, values, faith, culture, and anything else you would like to add, influence your expectations.

11. Are your cultural expectations being met? If yes, how? If not, why not? 
12. What religious expectations do you have of your Islamic school?

13. Why do you have these religious expectations? Describe how your background, values, faith, and culture influence your expectations.

14. Are your religious expectations being met? If yes, how? If not, why not?

15. What are your final thoughts on ways that Islamic schools in general can better meet your expectations? 